\title{
8. SITES 424 AND 425: GEOTHERMAL DRILLING ON THE GALAPAGOS RIFT
}

\author{
The Shipboard and Onshore Scientific Parties ${ }^{1}$
}

\section{SITE 424 (HOLE 424)}

Date occupied: 23 May 1977

Date departed: 24 May 1977

Time on hole: 26 hours

Position (latitude; longitude): $00^{\circ} 35.63^{\prime} \mathrm{N} ; 86^{\circ} 07.82^{\prime} \mathrm{W}$

Water depth (sea level; corrected m, echo-sounding): 2685

Water depth (rig floor; corrected $\mathbf{m}$, echo-sounding): 2701

Bottom felt (m, drill pipe): 2703.5

Penetration (m): 76

Number of holes: 1

Number of cores: 8

Total length of cored section $(\mathrm{m}): 76$

Total core recovered $(\mathrm{m}): 36.45$

Core recovery $(\%): 48$

Oldest sediment cored:

Depth sub-bottom (m): 37.5

Nature: $\mathrm{Mn}-\mathrm{Fe}$ sediment interlayered with nannofossilforaminifer ooze

Age: Pleistocene

\footnotetext{
${ }^{1}$ Roger Hekinian (Co-Chief Scientist), Centre Océanologique de Bretagne, Brest, France; Bruce R. Rosendahl (Co-Chief Scientist), Department of Geology, Duke University, Durham, North Carolina; John Barron, U. S. Geological Survey, Menlo Park, California; J. David Bukry, U. S. Geological Service, Scripps Institution of Oceanography, La Jolla, California; Yuri Dmitriev, Institute of Geology of Ore Deposits, Petrography, Mineralogy, and Geochemistry, Moscow, USSR; Ronald V. Fodor, Department of Geology and Institute of Meteoritics, University of New Mexico, Albuquerque, New Mexico (now at: Department of Geosciences, North Carolina State University, Raleigh, North Carolina); Robert M. Goll, Duke University Marine Laboratory, Beaufort, North Carolina; Michel Hoffert, Institut de Géologie, Strasbourg, France; Susan E. Humphris, Imperial College, London, United Kingdom (now at: Sea Education Association, Woods Hole, Massachusetts); George Lynts, Department of Geology, Duke University, Durham, North Carolina; David P. Mattey, Department of Geology, Bedford College, London, United Kingdom; James H. Natland, Scripps Institution of Oceanography, Deep Sea Drilling Project, La Jolla, California; Nikolai Petersen, Institut für Allgemeine und Angewandte Geophysik, Ludwig-MaximiliansUniversität, Munich, Federal Republic of Germany; William Roggenthen, Princeton University, Princeton, New Jersey (now at: South Dakota School of Mines and Technology, Department of Geology, Rapid City, South Dakota); Edward L. Schrader, Department of Geology, Duke University, Durham, North Carolina (now at: Department of Geology and Geography, University of Alabama, University, Alabama); Ramesh K. Srivastava, Institut für Petrographie und Geochemie der Universität Karlsruhe, Karlsruhe, Federal Republic of Germany (now at: Department of Geology, Rajasthan University, Udaipur, India); and Nick Warren, Department of Geology, University of California, Los Angeles, California.
}

Basement:

Depth sub-bottom (m): 38.5

Nature: basaltic rock

Velocity range $(\mathrm{km} / \mathrm{s}): 5.7$

\section{SITE 424 (HOLE 424A)}

Date occupied: 24 May 1977

Date departed: 24 May 1977

Time on hole: 16.2 hours

Position (latitude; longitude): $00^{\circ} 35.33^{\prime} \mathrm{N} ; 86^{\circ} 07.81^{\prime} \mathrm{W}$

Water depth (sea level; corrected $\mathbf{m}$, echo-sounding): no PDR depth

Water depth (sea level; corrected $\mathbf{m}$, echo-sounding): no PDR depth

Bottom felt (m, drill pipe): 2708.0

Penetration (m): 34.0

Number of holes: 1

Number of cores: 3 plus $1 \mathrm{X}$

Total length of cored section (m): 34.0

Total core recovered $(\mathrm{m}): 13.13$

Core recovery $(\%): 39$

Oldest sediment cored:

Depth sub-bottom (m): 33.4

Nature: Mn-Fe sediment interlayered with nannofossil ooze

Age: $200,000-400,000$ years

Basement:

Depth sub-bottom (m): 33.4

Nature: basaltic rock

Velocity range $(\mathrm{km} / \mathrm{s}): 5.7$

\section{SITE 424 (HOLE 424B)}

Date occupied: 25 May 1977

Date departed: 25 May 1977

Time on hole: 10.75 hours

Position (latitude; longitude): $00^{\circ} 35.82^{\prime} \mathrm{N} ; 86^{\circ} 07.82^{\prime} \mathrm{W}$

Water depth (sea level; corrected m, echo-sounding): 2705

Water depth (rig floor; corrected m, echo-sounding): 2696

Bottom felt (m, drill pipe): 2706

Penetration (m): 46.5

Number of holes: 1

Number of cores: 6

Total length of cored section (m): 46.5

Total core recovered $(\mathrm{m}): 29.30$

Core recovery $(\%): 63$ 
Oldest sediment cored:

Depth sub-bottom (m): 32.0

Nature: nannofossil-foraminiferal ooze

Age: $<200,000$ years

Basement:

Depth sub-bottom $(\mathrm{m}): 32.0$

Nature: basaltic rock

Velocity range $(\mathrm{km} / \mathrm{s}): 5.7$

\section{SITE 424 (HOLE 424C)}

Date occupied: 25 May 1977

Date departed: 25 May 1977

Time on hole: 5.5 hours

Position (latitude; longitude): $00^{\circ} 35.93^{\prime} \mathrm{N} ; 86^{\circ} 07.82^{\prime} \mathrm{W}$

Water depth (sea level; corrected $\mathbf{m}$, echo-sounding): 2699.0

Water depth (rig floor; corrected m, echo-sounding): 2710.5

Bottom felt (m, drill pipe): 2710.5

Penetration (m): 34.5

Number of holes: 1

Number of cores: 3

Total length of cored section $(\mathrm{m}): 16.5$

Total core recovered $(\mathrm{m}): 7.81$

Core recovery $(\%): 47$

Oldest sediment cored:

Depth sub-bottom (m): 26.7

Nature: foraminifer-nannofossil ooze

Age: Pleistocene

\section{Basement:}

Depth sub-bottom (m): 26.7

Nature: basaltic rock

Velocity range $(\mathrm{km} / \mathrm{s}): 5.7$

Principal results: The site consists of a north-south transect of four basement holes across a supposed geothermal mounds field about $22 \mathrm{~km}$ south of the Galapagos Spreading Center. Magnetic crustal age varies from about $0.60 \mathrm{~m} . \mathrm{y}$. at Hole $424 \mathrm{C}$ to $0.62 \mathrm{~m} . \mathrm{y}$. at Hole $424 \mathrm{~A}$. Two holes (424 and A) were targeted on mound-like features, which were found to consist of, at most, a very thin cap $(<30 \mathrm{~cm})$ of foraminiferal-nannofossil ooze overlying up to 15 meters of $\mathrm{Fe}-\mathrm{Mn}$ material intermixed with green hydrothermal muds, which in turn overlie up to 16 meters of foraminiferal-nannofossil ooze. Two other holes (424B and C) were targeted off mounds. Hole 424B shows up to 20 meters of green hydrothermal muds sandwiched between foraminiferal-nannofossil ooze units. Basement at all holes consists of fine- to coarse-grained plagioclase-pyroxene basalts with marked iron enrichment showing hyalopilitic, variolitic, intersertal, and subophitic textures. The basalts at all holes are virtually identical chemically but show variable magnetic inclination, probably the result of faultblock tilting. They show no obvious hydrothermal alteration.

\section{SITE 425 (HOLE 425)}

Date occupied: 26 May 1977

Date departed: 27 May 1977

Time on hole: 22 hours

Position (latitude; longitude): $01^{\circ} 23.68^{\prime} \mathrm{N} ; 86^{\circ} 04.22^{\prime} \mathrm{W}$
Water depth (sea level; corrected m, echo-sounding): 2850

Water depth (rig floor, corrected $\mathrm{m}$, echo-sounding): 2862

Bottom felt ( $\mathrm{m}$, drill pipe): 2872

Penetration (m): 110.0

Number of holes: 1

Number of cores: 9

Total length of cored section $(\mathrm{m}): 81.5$

Total core recovered $(\mathrm{m}): 43.42$

Core recovery $(\%)$ : 53

Oldest sediment cored:

Depth sub-bottom (m): 81.5

Nature: foraminifer-nannofossil ooze

Age: Pliocene?

Basement:

Depth sub-bottom (m): 81.5

Nature: massive basalt

Velocity range $(\mathrm{km} / \mathrm{s}): 5.6-6.2$

Principal results: The site is located $62 \mathrm{~km}$ north of the Galapagos Spreading Center just beyond the Olduvai magnetic event (slightly older than $1.8 \mathrm{~m} . \mathrm{y}$.), in a sediment-filled topographic depression, known to be characterized by high heat flow ( $~-5 \mathrm{HFU})$. We spot-cored through 81.5 meters of sediment, recovering 37.76 meters of foraminifer-nannofossil ooze and siliceous nannofossil ooze. The drill penetrated about 30 meters into basement; 5.66 meters of basalt or dolerite was recovered representing seven petrographic units. Major rock types are classed as pyroxeneplagioclase sparsely phyric, plagioclase phyric, and sparsely phyric, olivine-clinopyroxene-plagioclase sparsely phyric, and olivine-plagioclase sparsely phyric. They are not ironenriched to the same extent as those at Site 424. The basalts show evidence of hydrothermal alteration.

\section{BACKGROUND AND OBJECTIVES}

As explained in the general introduction to this volume, the choice of two sites drilled in the Panama Basin during Leg 54 (Figure 1) resulted from a directive to the Leg 54 scientific party to conduct "drilling tests" in areas targeted for an extensive future drilling program (Legs 69 and 70). Nominally, the objectives were mainly technical-to find the answers to these questions: Could the Glomar Challenger locate small, supposed geothermal mounds south of the Galapagos Rift? Could she then core them? Finally, could she spud into basement beneath the mounds with a mere 25 to 30 meters of sediment cover, or anywhere else in the Panama Basin, given the problems encountered in drilling basalts elsewhere in the Pacific where spreading rates are high?

Specific instructions were sent to the Challenger listing the Galapagos mounds geothermal field as our primary target, plus three alternative target locations on older crust of the Galapagos and Costa Rica Rifts. The scientific objectives of the spectrum of targets were twofold:

1) Investigate an active geothermal field where heat flow studies and near-bottom observations indicated ongoing flux of heated waters through the sediments, but primarily concentrated in sedimentary mounds up 


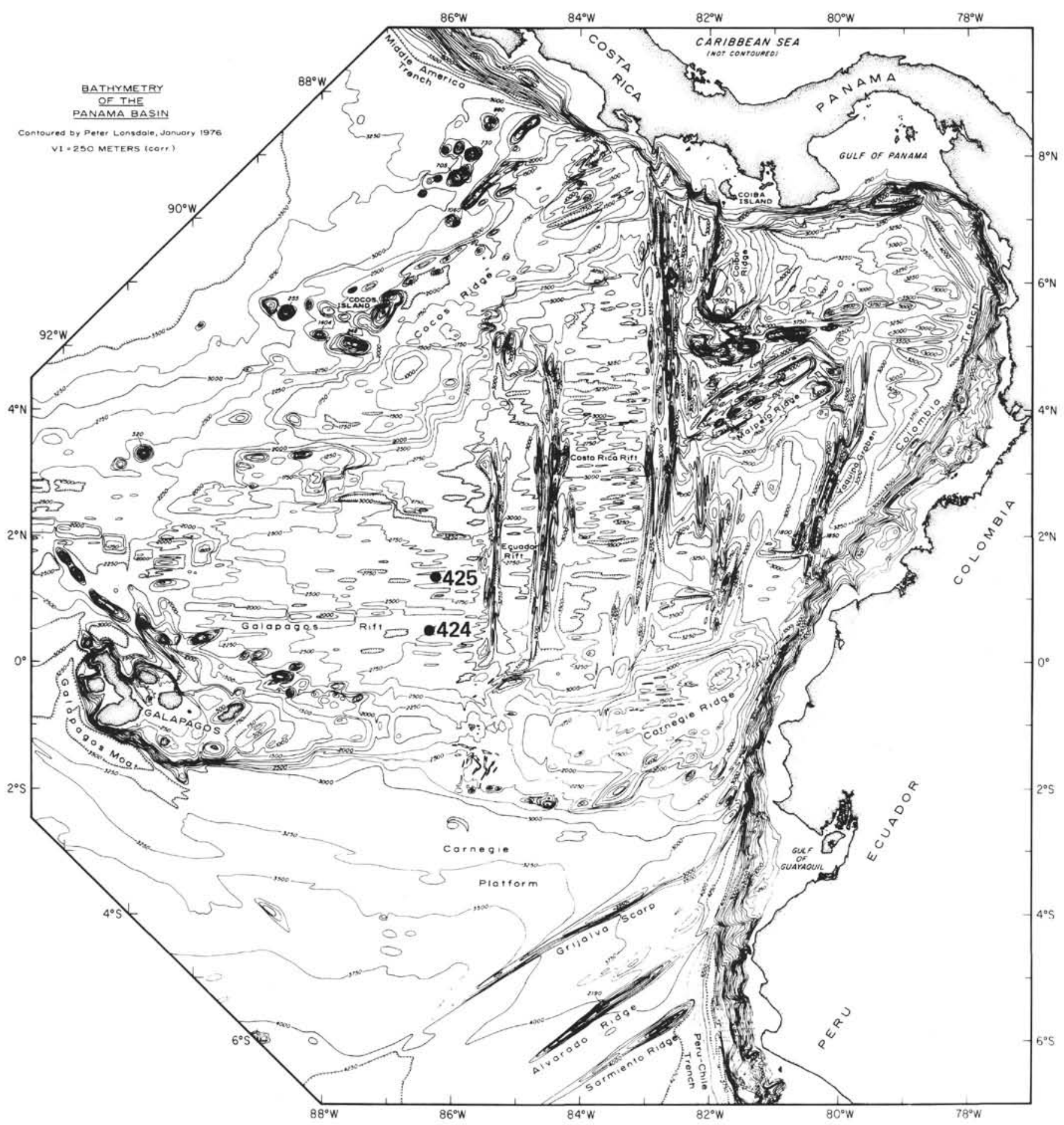

Figure 1. Location of Sites 424 and 425 in the Panama Basin, drilled during Leg 54. Bathymetry from Lonsdale and Klitgord (1978).

to 10 meters high capped with non-hydrogenous Fe-Mn oxides (Lonsdale, 1977; Corliss et al., 1978; Williams et al., 1974); and

2) Investigate an older segment of sea floor, one where heat flow measurements indicated that convective circulation of sea water in the crust had ceased, and conductive temperature gradients prevailed (Sclater and Klitgord, 1973; Williams et al., 1974).
Our own discussion of these objectives evolved considerably as we sailed due south toward the sites. In the five or six days of operations which remained to us at that time (we were later granted an extension), we felt obliged to conserve as much drilling time as possible. Any successful single-bit penetration into basement could take up well over half of the days available, yet at the mounds region in particular it was clear that it 
would be necessary to drill several holes to test the one hypothesis on their origin for which we had any information aboard ship. This was Lonsdale's (1977) interpretation of the mounds as precipitates from hydrothermal solutions vented from basement along small faults over which the mounds were primarily arrayed in rows, strips, and ridges. Our fundamental objective was indelibly clear, based on this hypothesis: to target prominent mounds as squarely as possible and core through them into basement which by every expectation should be hydrothermally altered, at least in narrow zones next to faults.

A secondary objective was to core through the 25 to 30 meters of sediments away from mounds, which deeptow near-bottom bathymetry and gravity cores indicated are primarily siliceous nannofossil ooze (Lonsdale, 1977). Two prominent reflectors in these sediments were thought by Lonsdale to be ash layers. These are arched upward conspicuously next to individual mounds, suggesting that they may somehow have been forced upward as hydrothermally produced sediments are precipitated from upward-venting fluids. The origin of these reflectors and the local pelagic sedimentation history were thus of fundamental importance.

Several factors operated against a full scientific evaluation of the mounds geothermal area by Leg 54 scientists. First, we had no heat flow data aboard to guide us in targeting mounds that might have had an unusually great flux of heated waters, or in targeting contrasting nearby low-heat-flow areas. Secondly, we had no heatflow or temperature-logging equipment aboard. Thirdly, we were only equipped to handle a standard shipboard pore-fluid program. Measurement of ammonia, dissolved silica, and dissolved gases was beyond our capability. We did make use of the Barnes in situ pore fluid sampler, but met with ambiguous results (see subsequent section on pore fluid chemistry in this chapter). By virtue of these limitations, and the scope of our collective expertise, we decided to concentrate our efforts on careful lithologic observations of sediments and basalts and on interpreting the stratigraphic and diagenetic history of the materials recovered.

The decision as to which target or targets we would drill in addition to the mounds became to a large extent dependent on the time spent in the mounds region. After drilling four holes there (Site 424), we had very little time left to steam to any of the alternative targets and scant chance of completing even one single-bit basement penetration to bit destruction. The alternative targets were all six to twelve hours steam to the south or southeast. Selection of any of them would have entailed back-tracking for a similar period on our return trip home. We deemed this too extravagant a use of our dwindling operations time and, instead, elected a target to the north of Site 424 on our route home. This target was selected to be effectively equivalent to the alternative targets in having sediments thicker than the mounds $(\sim 100 \mathrm{~m})$, and sufficient heat flow measurements to indicate that convective circulation of sea water in the crust had given way to a conductive geothermal regime. Thus, a site was targeted where three closely spaced heat flow values (Sclater and Klitgord, 1974) gave uniform results, and where the heat flow predicted theoretically for cooling oceanic lithosphere matched these values. The site selected (Hole 425) is $62 \mathrm{~km}$ north of the Galapagos Rift just to the south of a segment of crust abandoned during the ridge crest jump to the present Galapagos Rift (Sclater et al., 1974; Hey, 1977; Anderson et al., 1976; Lonsdale, 1977). Hole 425 is virtually due north of Site 424 .

\section{SITE 424 OPERATIONS}

After leaving Site 423 in the PT-4 Survey Area, we steamed south for six days to an area about $20 \mathrm{~km}$ south of the Galapagos Rise Crest, arriving in the region at about $1000 \mathrm{~h} 22$ May. Our task was to relocate and drill one or more small bathymetric features, resembling mounds or cones, that were thought to have been formed by localized hydrothermal phenomena. Although these features are well mapped on the basis of two SIO deeptow cruises (Figure 2), the sizes of the mounds or cones made our task a formidable one (Figure 3). Even where elongate, these features often are little longer or wider than the Challenger's dimensions ( $124 \mathrm{~m}$ and $20 \mathrm{~m}$, respectively), and are about equal in elevation to the height of the derrick floor from the sea surface $(10 \mathrm{~m})$.

Our strategy to relocate the mounds entailed firing a 20 -in. ${ }^{3}$ air gun on a two-second repetition rate and displaying the returned signal, filtered at $80-360 \mathrm{~Hz}$, on

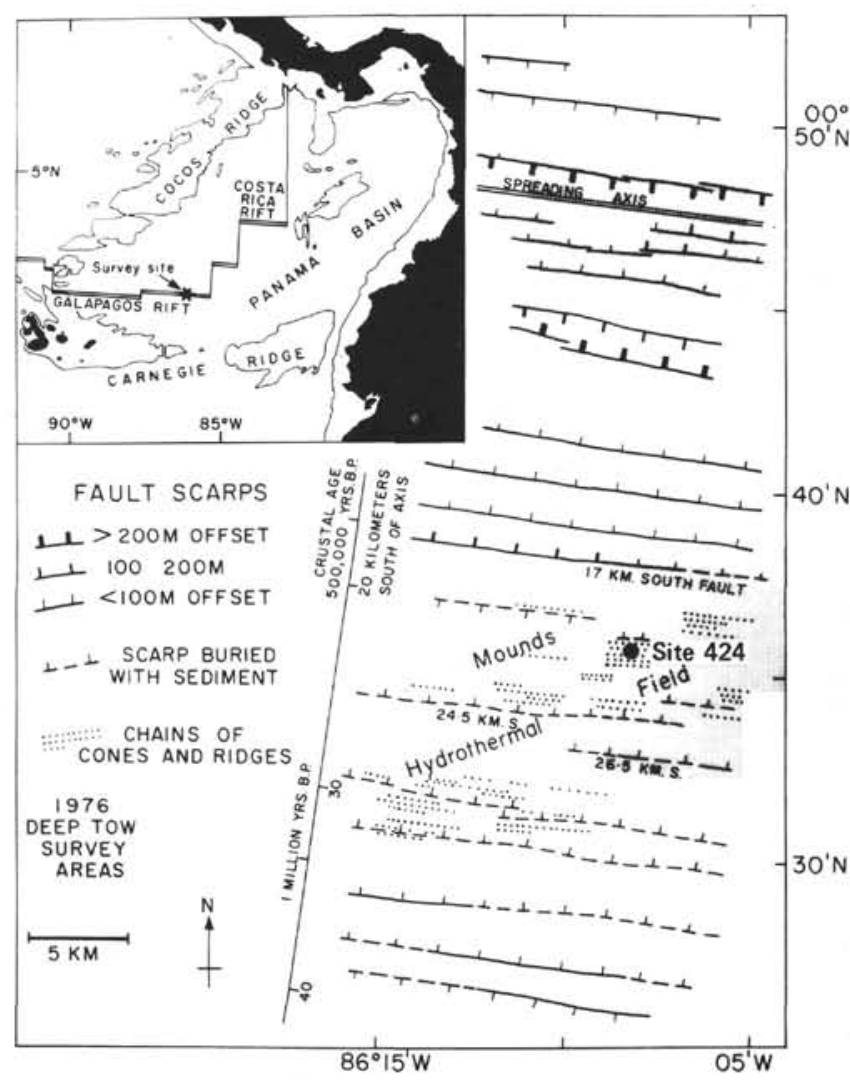

Figure 2. Setting of the Galapagos mounds geothermal field on the south flank of the Galapagos Rift, from Lonsdale (1977) with permission. 

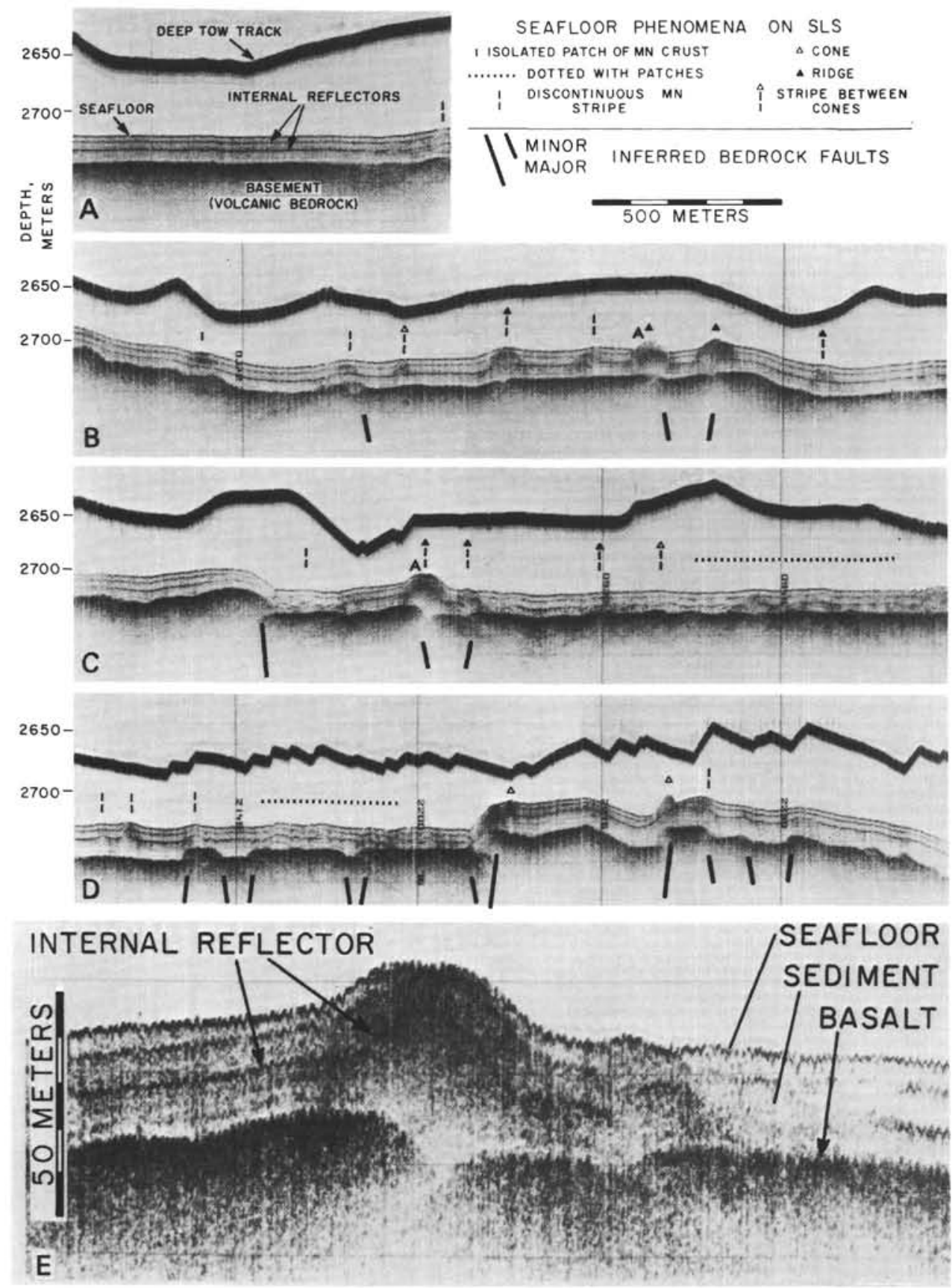

Figure 3. (A-D) Near-bottom, deep-tow 3.5-kHz profiles of the mounds geothermal field; (E) detail of mound from deep-tow $3.5-\mathrm{kHz}$ records; from Lonsdale (1977) with permission. Note upward arching of reflectors toward mound in (B) and continuity of deeper reflector through mound. The reflectors appear locally discontinuous and at different depths on right side of record.

the EDO recorder operating on a two-second sweep. At a reduced profiling speed of 3.5 to 4.5 knots $(\sim 2 \mathrm{~m} / \mathrm{s})$, this would produce an interval of 5 to 15 sweeps upon which vertically incident signals from the mounds could be recorded (assuming a ship track perpendicular to the mounds). Because the mounds were known to be steepsided and encrusted with manganese and tended to lie along semi-continuous chains (Lonsdale, 1977), we reasoned that 5 to 15 sweeps should be adequate to define abrupt lateral changes in the intensity of reflections returned from a section of sea floor bisected by a mound chain, or at least to display an elevated point reflector and its hyperbola originating from a mound chain. Once a mound had been located in this way and a beacon deployed, our plan was to run in drill pipe to a depth of about 10 meters above the sea floor, lower the EDO re-entry sonar scanning tool down the drill string, and begin a sonar search for the mound. Using this 
EDO tool, we would position the ship over the mound in the same way that the ship is moved into position over a re-entry cone. The main uncertainty with this plan was that the re-entry tool had to be removed from the drill string before actual penetration could be attempted, and during this interval $(\sim 90 \mathrm{~min})$ the drill string was subject to random excursions of perhaps 20 feet in spite of the calm seas. In effect, this meant that even though the ship could be centered over a mound the drill string might not have been.

Four holes were drilled at Site 424. Coring summaries are given in Table 1.

\section{Hole 424}

On the first pass through the "Mounds Hydrothermal Field" (Figure 4), we were able to pick up several point reflectors and associated hyperbolae (Figure 5) in the northwest group of mounds. On our second pass through the area we passed slightly to the east of the northwest group of mounds (Figure 4) and in any case would not have been able to distinguish mound reflections because our speed was greatly increased by a 2.5 to 3.0 -knot current from the south-southeast. The realization of this came not from navigation (the satellite coverage was very poor at this time), but by plotting the magnetic total field along this track line and comparing
TABLE 1

Coring Summary, Site 424

\begin{tabular}{|c|c|c|c|c|c|c|c|}
\hline Core & $\begin{array}{c}\text { Date } \\
\text { (May 1977) }\end{array}$ & Time & $\begin{array}{l}\text { Depth From } \\
\text { Drill 1 Hoor } \\
\text { (m) }\end{array}$ & $\begin{array}{l}\text { Depth Below } \\
\text { Sea Floor } \\
\text { (m) }\end{array}$ & $\begin{array}{l}\text { Length } \\
\text { Cored } \\
(\mathrm{m})\end{array}$ & $\begin{array}{l}\text { Length } \\
\text { Recovered } \\
\text { (m) }\end{array}$ & $\begin{array}{c}\text { Recovery } \\
\text { (\%) }\end{array}$ \\
\hline \multicolumn{8}{|c|}{ Hole 424} \\
\hline 1 & 23 & 0540 & $2703.5-2713.0$ & $0.0-9.5$ & 9.5 & 2.16 & 23 \\
\hline 2 & 23 & 0627 & $2713,0-2722.5$ & $9.5-19.0$ & 9.5 & 9.03 & 95 \\
\hline 3 & 23 & 0724 & $2722.5-2732.0$ & $19.0-28.5$ & 9.5 & 9.46 & $99+$ \\
\hline 4 & 23 & 1045 & $2732.0-2741.5$ & $28.5-38.0$ & 9.5 & 8.82 & 93 \\
\hline 5 & 23 & 1355 & $2741.5-2751.0$ & $38.0-47.5$ & 9.5 & 4.01 & 42 \\
\hline 6 & 23 & 1400 & $2751.0-2760.5$ & $47.5-57.0$ & 9.5 & 2.87 & 30 \\
\hline 7 & 23 & 2227 & $2760.5-2770.0$ & $57.0-66.5$ & 9.5 & 0.10 & 1 \\
\hline 8 & 24 & 0201 & $2770.0-2779.5$ & $66.5-76.0$ & 9.5 & 0.00 & 0 \\
\hline Total & & & & & 76.0 & 36.45 & 48 \\
\hline \multicolumn{8}{|c|}{ Hole 424A } \\
\hline 1 & 24 & 1928 & $2708.0-2723.0$ & $0.0-15.0$ & 15.0 & 2.61 & 17 \\
\hline 2 & 24 & 2022 & $2723.0-2732.5$ & $15.0-24.5$ & 9.5 & 5.20 & 55 \\
\hline 3 & 24 & 2229 & $2732.5-2742.0$ & $24.5-34.0$ & 9.5 & 5.32 & 56 \\
\hline $1 x^{3}$ & 24 & & $?-?$ & $?-?$ & - & $(0.51)$ & - \\
\hline Total & & & & & 34.0 & 13.13 & 39 \\
\hline \multicolumn{8}{|c|}{ Hole 424B } \\
\hline 1 & 25 & 0245 & $2710.0-2713.5$ & $0.0-3.5$ & 3.5 & 3.05 & 87 \\
\hline 2 & 25 & 0334 & $2713.5-2723.0$ & $3.5-13.0$ & 9.5 & 8.50 & 89 \\
\hline 3 & 25 & 0425 & $2723.0-2732.5$ & $13.0-22.5$ & 9.5 & 9.40 & 99 \\
\hline 4 & 25 & 0520 & $2732.5-2742.0$ & $22.5-32.0$ & 9.5 & 6.00 & 63 \\
\hline 5 & 25 & 0730 & $2742.0-2751.5$ & $32.0-41.5$ & 9.5 & 1.30 & 14 \\
\hline 6 & 25 & 1020 & $2751.5-2756.5$ & $41.5-46.5$ & 5.0 & 1.05 & 21 \\
\hline Total & & & & & 46.5 & 29.30 & 63 \\
\hline \multicolumn{8}{|c|}{ Hole $424 \mathrm{C}$} \\
\hline 1 & 25 & 1157 & $2710.5-2720.0$ & $0.0-9.5$ & 9.5 & 6.98 & 73 \\
\hline Wash & 25 & & $2720.0-2738.0$ & $9.5-27.5$ & & $=$ & - \\
\hline 2 & 25 & 1328 & $2738.0-2742.0$ & $27.5-31.5$ & 4.0 & 0.35 & 9 \\
\hline 3 & 25 & 1617 & $2742.0-2745.0$ & $31.5-34.5$ & 3.0 & 0.48 & 16 \\
\hline Total & & & & & 16.5 & 7.81 & 47 \\
\hline
\end{tabular}

Unable to go back to bottom. The recovery is probably slumped material. This interval was not coted and the recovery is not included in the total length recovered.

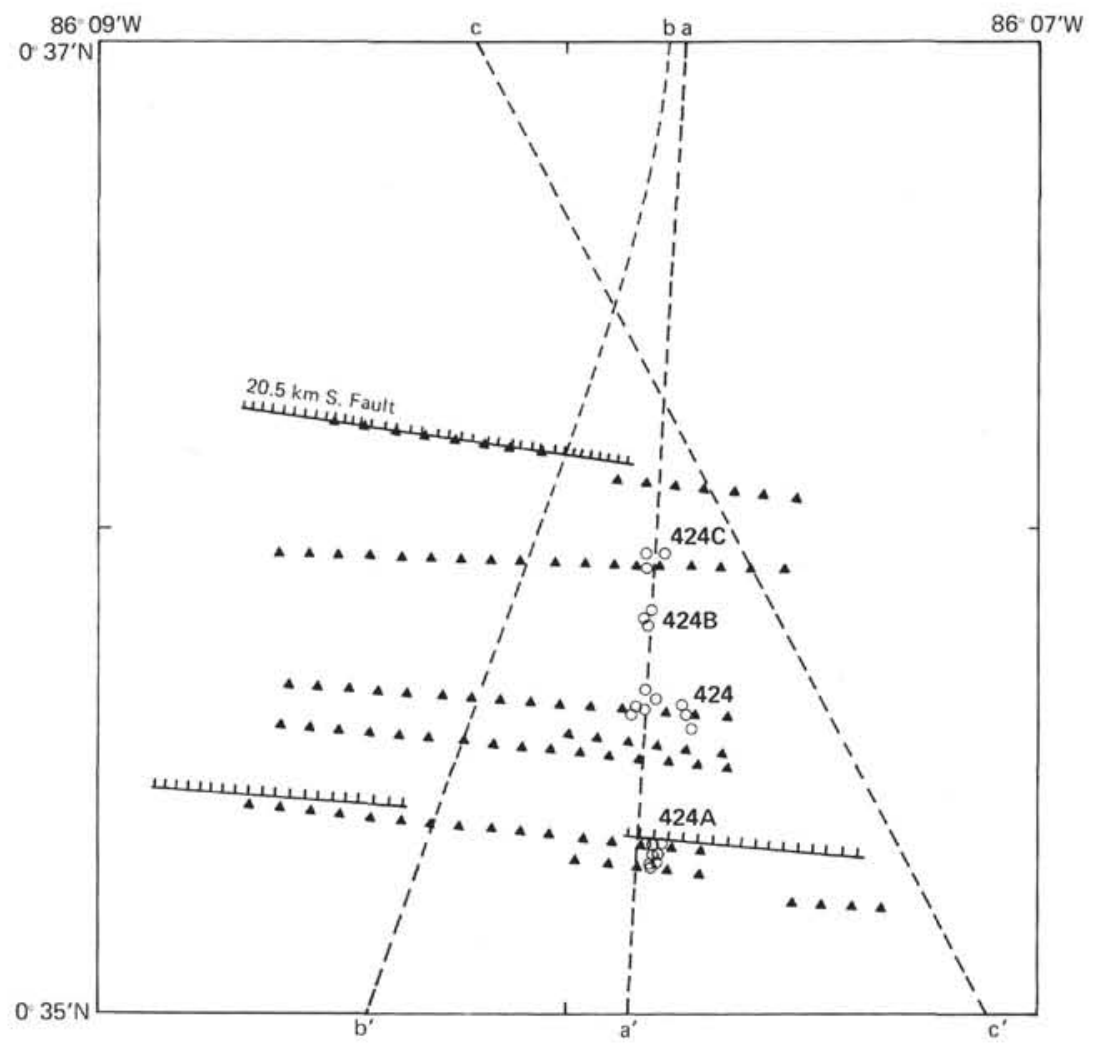

Figure 4. Diagram showing location of mound ridges (triangles), hole locations indicated by satellite fixes (open circles, three or more per hole) and Glomar Challenger and deep-tow profiles (dotted lines) used on other figures. 


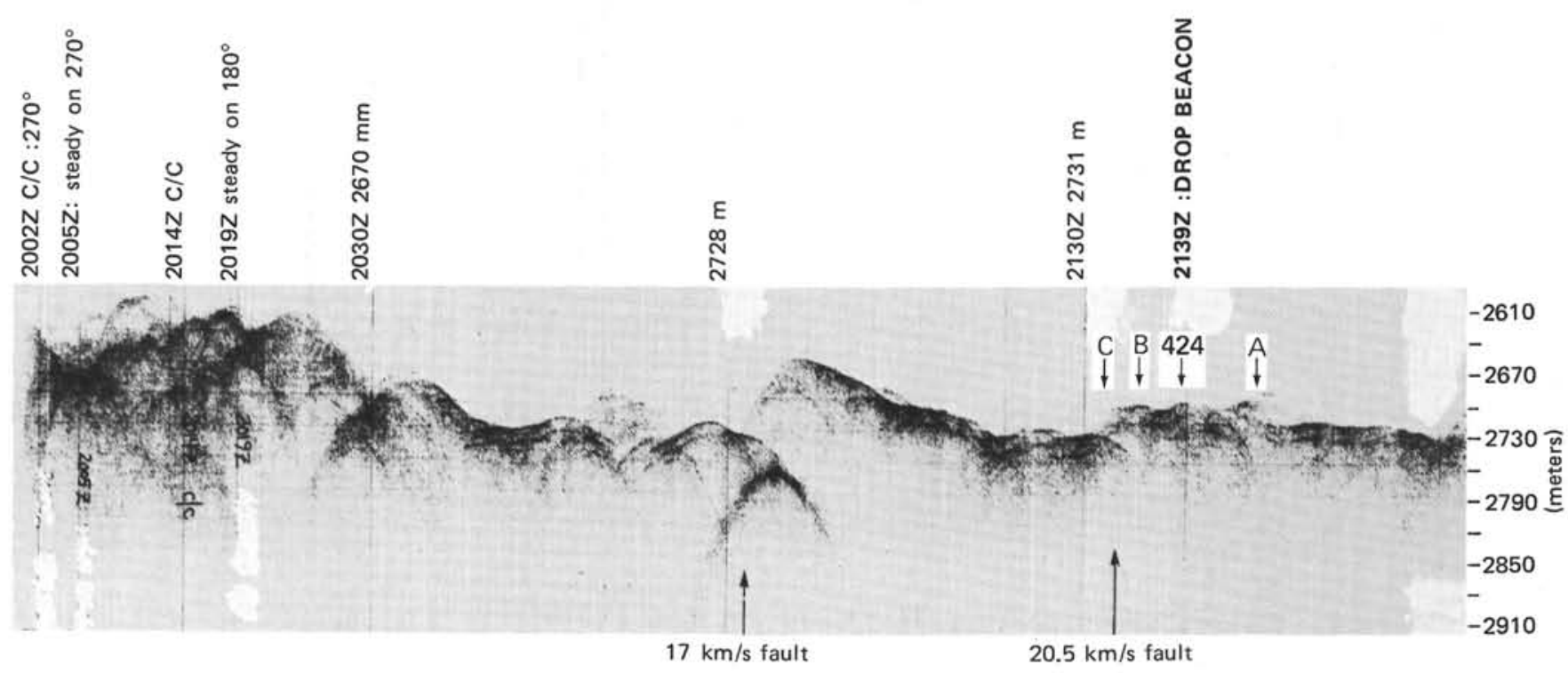

Figure 5. A portion of the Glomar Challenger 12-kHz record showing location of beacon drop, holes at Site 424, and basement faults (compare with Figure 6). Note failure of $12-\mathrm{kHz}$ system to resolve mounds or internal basement stratigraphy. A 3.5-kHz system for the Challenger was installed only after Leg 54.

it to that observed on the first pass through the area. Indeed, it turned out that magnetics provided a remarkably good control on latitude. By combining this control with that obtained by correlating our reflection profiles with those obtained from the deep-tow instrument (Figure 6), we were able to locate reflection discontinuities on our third pass through the northwest mounds field. At 1438 we dropped a beacon over the southern edge of a discontinuity that we thought could be one of the mound chains described by Lonsdale (1977). The drop site turned out to be located on the third mound chain, going north to south, in the northwest group of mounds (Figure 7).

After positioning the ship over the beacon, we began running in pipe at 1718. An F93C three-cone bit was used and the top two bumper subs and three 8-1/4-in. drill collars were removed because the predicted sediment thickness was only 28 meters. At 2130 we reached the 10-meter height above the sea floor, lowered the EDO tool, and at 2347 began scanning. We immediately picked out the beacon on the sea floor and two relatively distinct reflectors within 90 feet of it. By 0308, 23 May, we were positioned directly over one of the targets, which appeared to be elevated about seven meters above the surrounding sea floor. After removing the EDO tool, we spudded in at 0508 . It should be noted that the $12-\mathrm{kHz}$ echo sounder proved to be totally worthless during this and subsequent operations in the mounds area (at the time the ship was not equipped with a $3.5-\mathrm{kHz}$ unit). Only once did it pick up a returned signal that may have represented a mound and this is far from certain.

Hole 424 was cored continuously through 31 meters of sediment and 45 meters of basalt, of which 28.8 meters of sediment and 8.45 meters of basalt were recovered. In spite of the fact that basement drilling conditions at Hole 424 were better than those en- countered at any previous hole during Leg 54 , it became apparent that the basalt was extremely abrasive and wearing out the bit at an alarming rate. Between the first piece of cored basalt recovered and the base of Core 7 (representing about $28 \mathrm{~m}$ of basement penetration), the diameter of the basalt cores decreased from their normal value of $6 \mathrm{~cm}$ to less than $5 \mathrm{~cm}$. Drilling at Hole 424 was terminated at 020124 May, when Core 8 came up empty and we inferred that the bit was worn out. This did, indeed, prove to be the case-after a mere 10.8 hours of rotation.

\section{Hole 424A}

At 070024 May, we began incremental offsets to the south using the echo sounder to locate a small fault scarp, just south of which two mound chains were known to exist (Figure 7). By 0759 the ship was positioned 1750 feet south of the original beacon and about 100 feet south of the fault scarp. After running in pipe to a depth of about 12 meters above the sea floor, the EDO tool was again lowered down the drill string and a sonar search begun at 1429 . Several targets were visible on the 250- and 500-foot scans and we began maneuvering towards the largest. By 1648 the ship was in position over this target, which was 8 to 9 meters high and situated a total of 2030 feet south and 120 feet west of the beacon. The onsite satellite positions, shown in Figure 4, indicate we were probably located on the sixth mound chain (north to south) in the northwest group of mounds. Spud-in occurred at 1850 .

Hole 424A was cored continuously through 33.4 meters of sediment and 5 meters of fractured basalt. Total recovery was 13.03 meters of sediment and 0.10 meter of basalt. A decision was made to terminate the hole at 2330 , when we were unable to get back to the bottom of the hole after attempting this for an hour. We felt that the hole was too unstable and torqueing too high to risk 


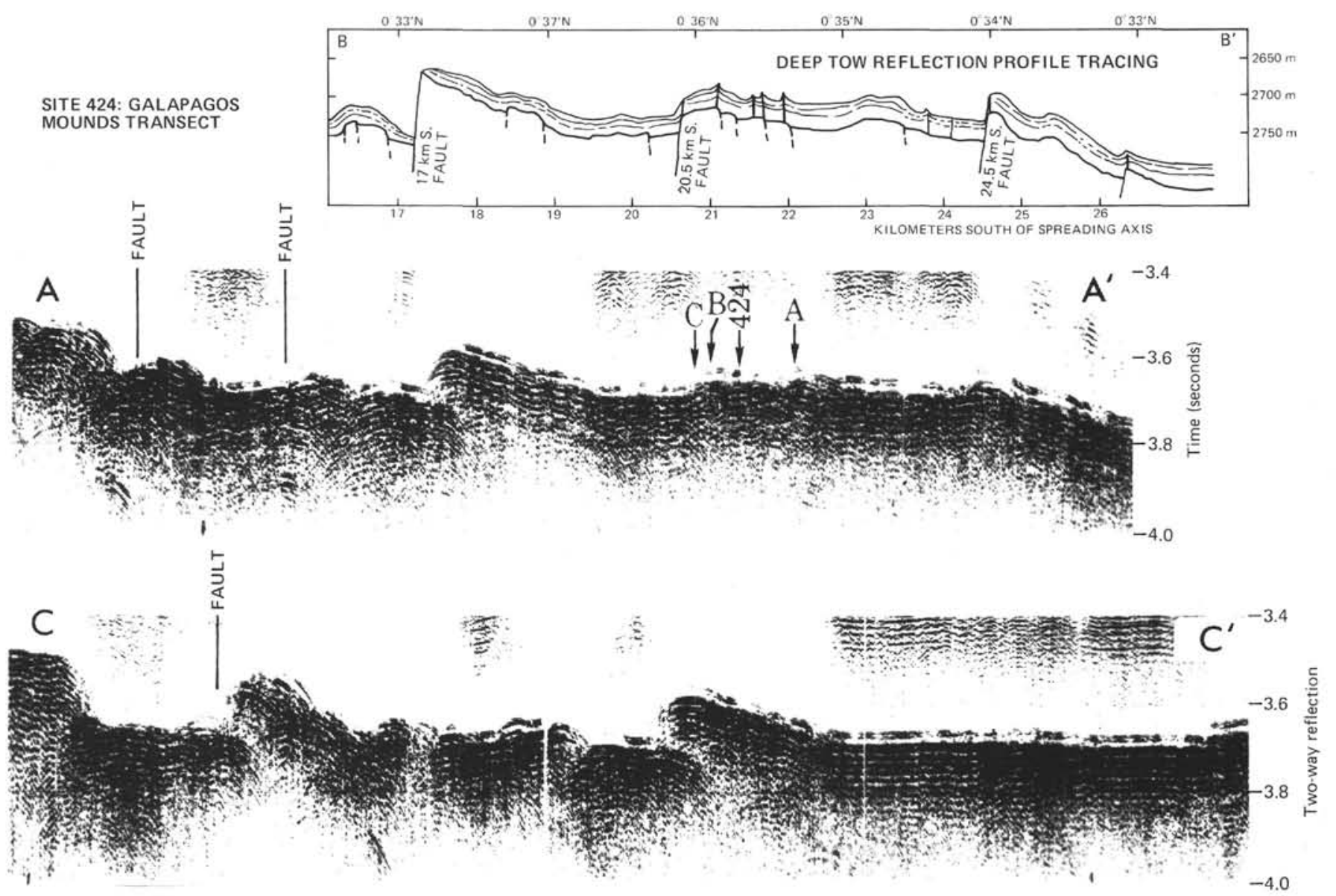

Figure 6. Tracing of deep-tow 3.5-kHz reflection profile (track B-B' of Figure 4) compared with two Glomar Challenger air-gun profiles (tracks $A-A^{\prime}$ and $C-C^{\prime}$ of Figure 4). Small darkened peaks on $B-B^{\prime}$ are mounds. Ship speed and air-gun repetition rate were adjusted to make the profiles as close as possible to the scale of the deep-tow profile. Note discontinuous return from surface of sediments in air-gun profiles, probably caused by scattering from mounds.

loss of the BHA for what appeared to be minimal recovery.

\section{Hole 424B}

After leaving Hole 424A, we moved 1200 feet north of the Site 424 beacon to a location that was clearly away from any known mound chains. The main objective at Hole 424B was to establish an areal reference section against which the mound holes could be compared. Having made this move with the drill string intact but raised 200 meters above the sea floor, we avoided the need for reassembling the string. Drilling commenced at 021525 May. Again, the sedimentary section was cored continuously to basement, which was encountered at a sub-bottom depth of 32 meters. After penetrating 14.5 meters of basalt and recovering 2.35 meters, we encountered the same difficulties as those described previously for Hole 424A in spite of spotting 50 barrels of mud. At 1030, Hole 424B was abandoned.

\section{Hole 424C}

Since the drilling personnel felt that we still had several hours of rotation left in the bit used at Holes
$424 \mathrm{~A}$ and $\mathrm{B}$, we decided to offset another 650 feet north of Hole 424B ( $\sim 600 \mathrm{~m}$ north of the Site 424 beacon) and attempt a final hole in this area. Our objective was to core part of the sedimentary section for reference purposes and obtain a basement sample at a fourth location along the Site 424 drilling transect. Drilling operations began at 1120 hours LCT. After alternately coring and washing through about 31 meters of sediment and coring 3 meters of basalt, recovering 0.48 meter, drilling was terminated at 1630 because of unsafe hole conditions and a nearly worn-out bit.

\section{SITE 425 OPERATIONS}

Leaving Hole $424 \mathrm{C}$, we proceeded due north to Site 425 , located about $62 \mathrm{~km}$ north of the Galapagos Spreading Center. The site is positioned just beyond the Olduvai magnetic event (slightly older than $1.8 \mathrm{~m} . \mathrm{y}$.) in a topographic depression blanketed with about $0.11 \mathrm{sec}-$ ond (two-way reflection time) of sediment. This depression was known to be characterized by high heat flow $(\sim 5$ HFU) from the work of Sclater and Klitgord (1973), and we thought the locality might represent the upwelling limb of a hydrothermal convection cell. In 


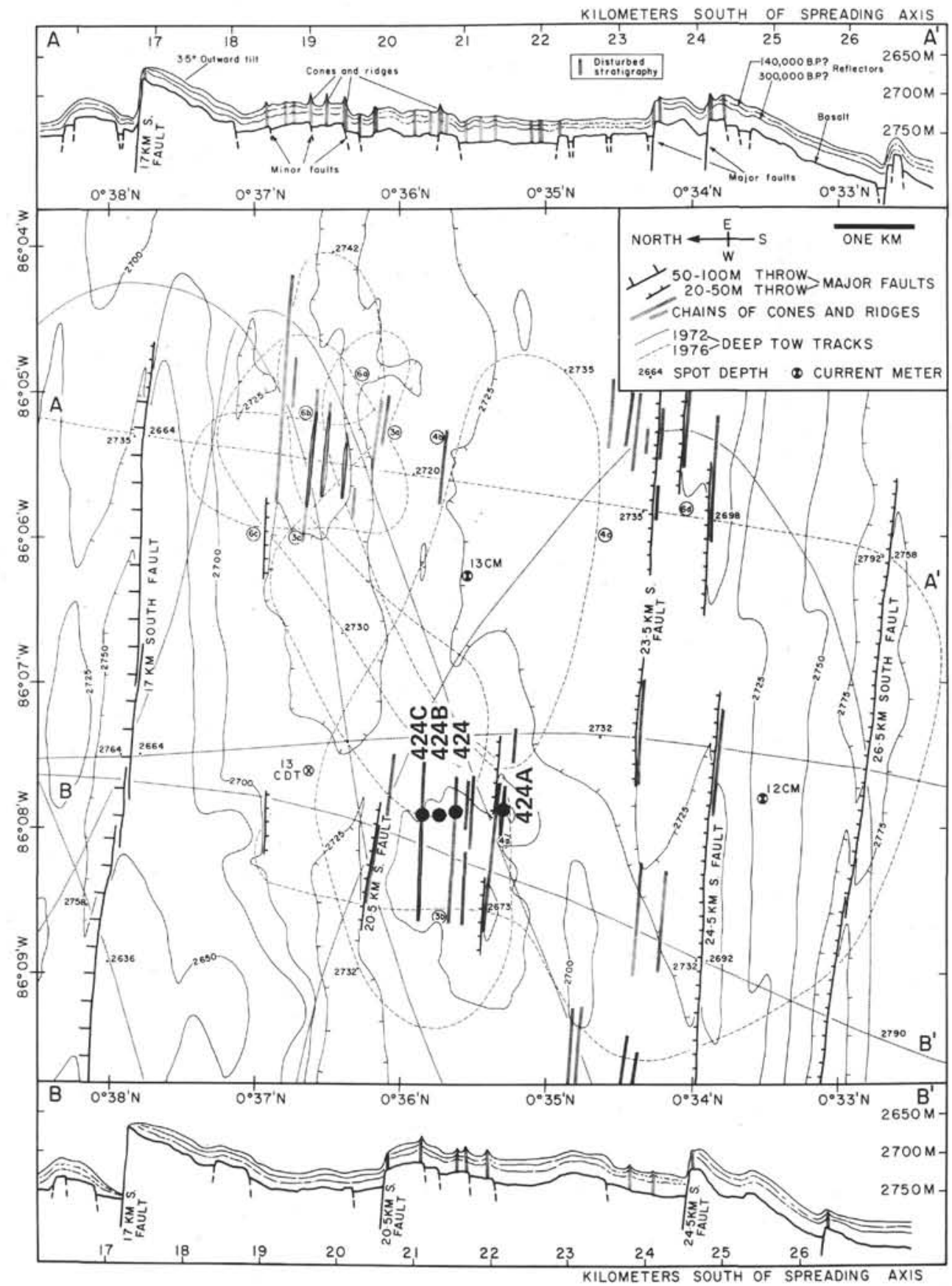

Figure 7. Bathymetry of a portion of the Galapagos mounds geothermal field, based on 1977 and 1976 deep-tow surveys (from Lonsdale, 1977, with permission). Track $A-A^{\prime}$ of Figure 4 is not the same as that shown here, but $B-B^{\prime}$ is.

operational terms this meant that some cementation of the basalts could have occurred, enhancing the probability of successful basement penetration.

At 030826 May, we dropped a beacon on a uniform portion of the local sediment blanket (Figure 8) and started running in pipe at 0430. Again, a shortened BHA was utilized (see Site 424 Operations). After alternately coring and washing through 81.5 meters of sediment, basement drilling began at about 1500 . The first core in the basalt was cut relatively easily in about 74 minutes. The second and third cores were progressively more difficult and each required spotting 25 barrels of mud. While attempting to cut the fourth basalt core, torqueing and sticking became severe and soon the bit became plugged. The hole was abandoned at 0230, 27 May, and after 425,000 pounds of pull were required to unstick the pipe. A coring summary is given in Table 2 .

Total basement penetration at Site 425 was about 30 meters, and 5.66 meters of basalt was recovered. Most of the trouble at this site seemed to originate in a rubbly 


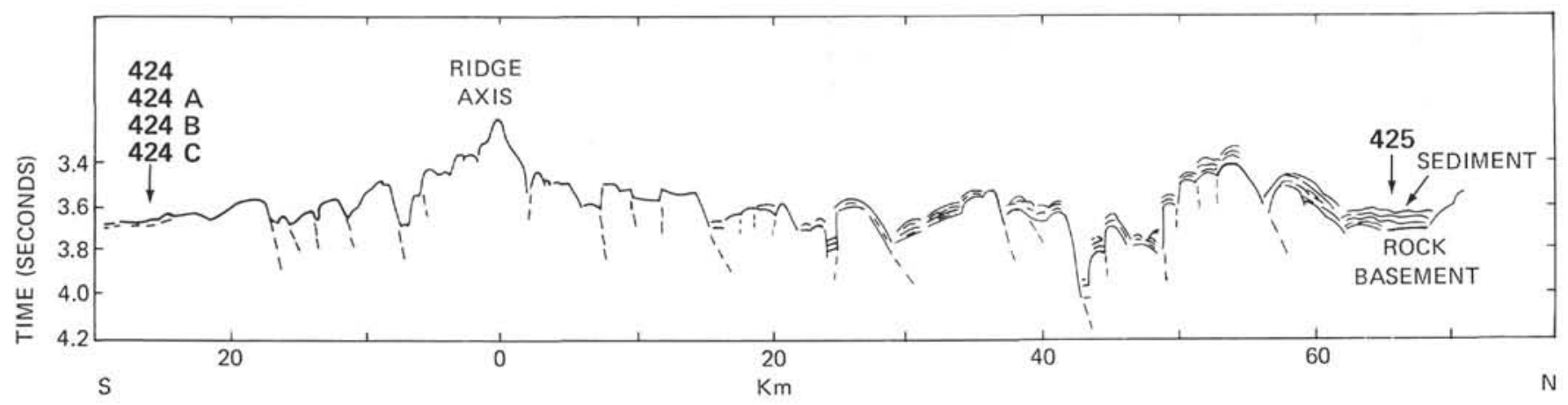

Figure 8. Line drawing of Glomar Challenger air-gun profile between Site 424 and Hole 425, showing fault-block structure and sediment distribution on either side of the Galapagos Rift axis. Dashed lines are extrapolated faults into basement based on surface topography.

TABLE 2

Coring Summary, Hole 425

\begin{tabular}{|c|c|c|c|c|c|c|c|}
\hline Core & $\begin{array}{c}\text { Date } \\
\text { (May 1977) }\end{array}$ & Time & $\begin{array}{l}\text { Depth From } \\
\text { Drill Floot } \\
\text { (m) }\end{array}$ & $\begin{array}{l}\text { Depth Below } \\
\text { Sea Floor } \\
\text { (m) }\end{array}$ & $\begin{array}{l}\text { Length } \\
\text { Cored } \\
\text { (m) }\end{array}$ & $\begin{array}{l}\text { Length } \\
\text { Recovered } \\
\text { (m) }\end{array}$ & $\begin{array}{c}\text { Recovery } \\
(\%)\end{array}$ \\
\hline 1 & 26 & 1044 & $2872.0-2877.5$ & $0.0-5.5$ & 5.5 & 4.81 & $100+$ \\
\hline $2^{2}$ & 26 & 1140 & $2877.5-2887.0$ & $5.5-15.0$ & 9.5 & 8.62 & 91 \\
\hline Washed & & & & & & & \\
\hline $\begin{array}{c}3 \\
\text { Washed }\end{array}$ & 26 & 1242 & $2896.5-2905.0$ & $24.5-34.0$ & 9.5 & 9.49 & $99+$ \\
\hline & 26 & 1335 & $2915.5-2923.0$ & $43.5-53.0$ & 9.5 & 5.51 & 58 \\
\hline 5 & 26 & 1431 & $2934.5-2944.0$ & $62.5-72.0$ & 9.5 & 6.23 & 66 \\
\hline 6 & 26 & 1530 & $2944.0-2953.5$ & $72.0-81.5$ & 9.5 & 3.10 & 33 \\
\hline 7 & 26 & 1750 & $2953.5-2963.0$ & $81.5-91.0$ & 9.5 & 1.89 & 20 \\
\hline 8 & 26 & 2033 & $2963.0-2972.5$ & $91.0-100.5$ & 9.5 & 1.09 & 11 \\
\hline 9 & 27 & 0055 & $2972.5-2982.0$ & $100.5-110.0$ & 9.5 & 2.68 & 28 \\
\hline Total & & & & & 81.5 & 43.42 & 53 \\
\hline
\end{tabular}

or fragmented zone about 15 meters into basement, and there is some speculation that a cementing or gel capability could have increased the drilling time in this hole beyond the 6.7 hours of rotation we achieved. It should be noted that, in fact, some minor cementation was observed in the basalts recovered at Site 425 .

\section{SEDIMENT LITHOLOGY, SITE 424}

The holes drilled south of the Galapagos Spreading Center (Holes 424, 424A, B, and C) constitute a northsouth transect on very young oceanic crust, about 600,000 years old, on the basis of magnetic anomalies. Because they generally have similar lithological characteristics, the sediment descriptions for the various holes are grouped together here. The recovery in each core and the distribution of sediment types in the holes are shown on Figure 9. It should be noted that most of the recovered sediments were moderately to extensively disturbed by the coring process.

Based on visual observations and chemical tests, the various sediments and deposits are classified into four main sediment types: $\mathrm{Fe}-\mathrm{Mn}$ hydroxides; green nontronitic mud; foraminifer-nannofossil ooze; and siliceous nannofossil ooze. There are also minor siliceous ash-rich layers.

The $\mathrm{Fe}-\mathrm{Mn}$ hydroxides and green muds are the principal materials of the mounds (Holes 424 and 424A) and most probably had a hydrothermal origin. These two types of materials occur in three forms: pure green mud; $\mathrm{Fe}-\mathrm{Mn}$ material intermixed with green mud; and $\mathrm{Fe}-\mathrm{Mn}$ concretions.

\section{Pure Green Mud}

This type of deposit occurs mainly in Hole 424B, where it attains a thickness of up to 20 meters and is capped with siliceous nannofossil ooze. It also occurs in Hole 424A, but as thin layers about $5 \mathrm{~cm}$ thick (Figure 9) interlayered with foraminifer-nannofossil ooze. The colors of these types of deposits are as follows: dusky brown $(5 \mathrm{YR} 2 / 2)$, grayish olive $(5 \mathrm{GY} 3 / 2)$, moderate olive-brown (5Y4/4), greenish black $(5 \mathrm{G} 2 / 1)$, and dark yellowish green (10GY4/4).

The green hydrothermal mud is made up of irregular platy, friable grains, varying in size from about 0.1 to $0.5 \mathrm{~cm}$ in diameter. Microscopically these materials are anisotropic and slightly birefringent. X-ray diffraction data (Hoffert et al., this volume; Schrader et al., this volume; Donnelly, this volume; Dymond et al., this volume; Rateev et al., this volume) indicate that these are primarily nontronitic. These authors also list chemical analyses showing these clays to be $\mathrm{K}, \mathrm{Fe}$-smectites with very low $\mathrm{Al}_{2} \mathrm{O}_{3}(<1 \%)$ content. In these respects, they seem to compare with types of hydrothermal deposits encountered elsewhere (e.g., Hoffert et al., 1978; Hekinian et al., this volume).

Debris of an organic nature in these muds is rare. The presence of a few coccoliths and other fragments of siliceous organisms may be due to contamination during coring. Oxides and hydroxides of manganese also seem to be rare in this type of deposit.

\section{Fe-Mn Material Intermixed With Green Hydrothermal Mud}

This type of deposit is easily distinguishable in the cores of Hole 424, where it is abundantly represented. It is less abundant at Hole 424B and is missing at the other holes. The colors of this type of deposit are as follows: dark gray $(\mathrm{N} 3)$, grayish black $(\mathrm{N} 2)$, greenish black $(5 \mathrm{GY} 2 / 1)$, olive-black $(5 \mathrm{Y} 2 / 1)$, and dark yellowish green $(10 \mathrm{GY} 4 / 4)$.

These deposits are similar in composition to those of the green hydrothermal mud, but in addition contain many fragments and concretions of $\mathrm{Fe}-\mathrm{Mn}$ material, the size of which varies from $1 \mathrm{~mm}$ to $2 \mathrm{~cm}$. The smaller $\mathrm{Fe}-\mathrm{Mn}$ concretions seem to be rounded with botryoidal shapes. Much of the mixing appears to have been mechanical (induced by coring), but in some cases dark 

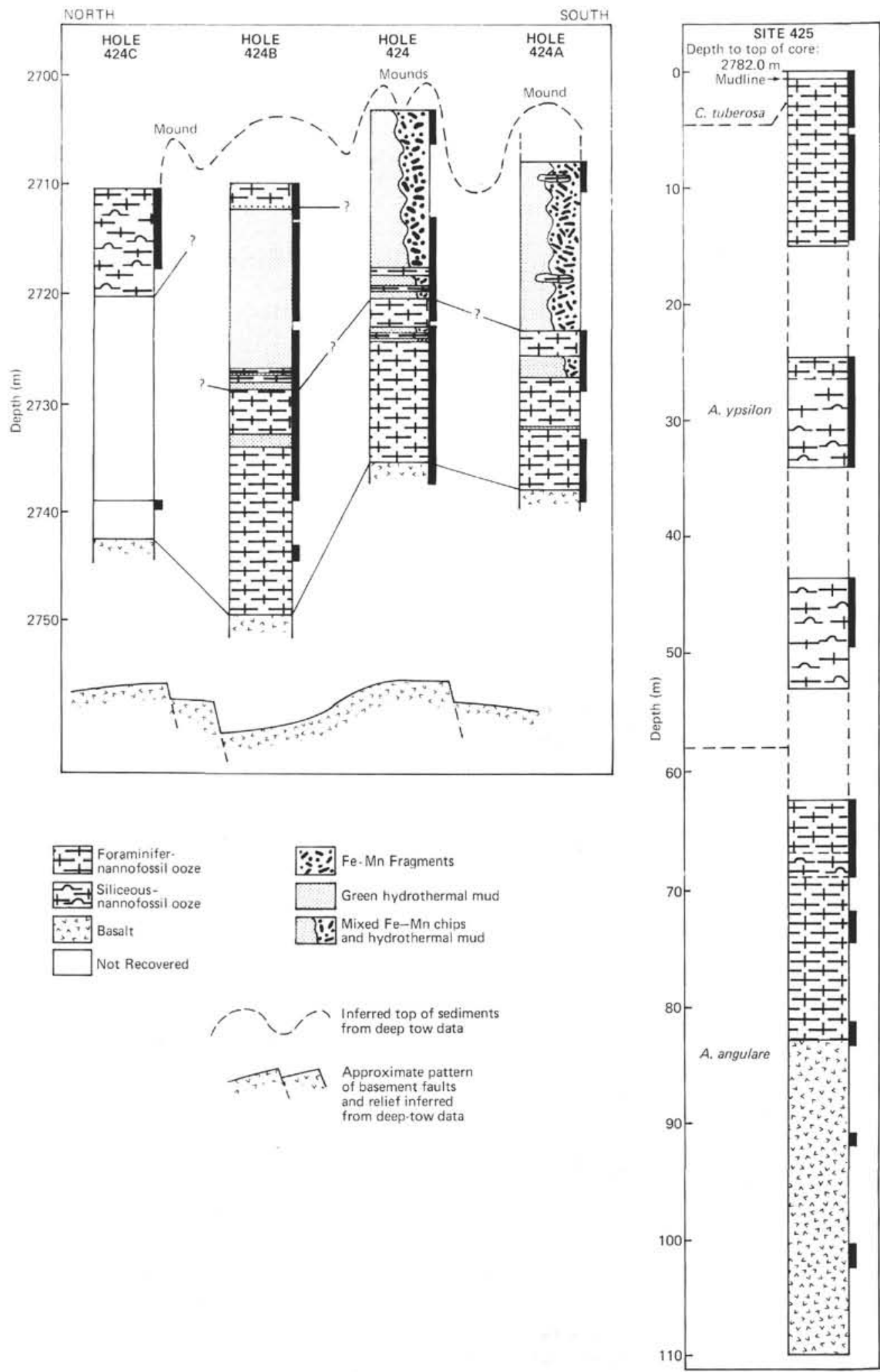

Figure 9. Lithologic columns for sediments of Site 424 and Hole 425. Holes 424, $424 A, B$, and $C$ were drilled approximately 300 meters from each other on a northsouth line. Core recovery is indicated by black bars to right of columns (top of each bar is top of a core). Lines between columns indicate possible biostratigraphic correlations. Dashed line at top indicates inferred sediment surface based on Figure 8 and mudline core of Hole 424C. Stippled schematic basement profile below Site 424 columns is shown to indicate placement of basement faults. 
gray earth chips of material which have not been disturbed by drilling consist of the same two end members (Schrader et al., this volume).

\section{Fe-Mn Concretions}

The name concretions is given here to angular, irregular, oval, and elongate, black and dark greenish gray $\mathrm{Fe}-\mathrm{Mn}$ material of about 3 to $4 \mathrm{~cm}$ diameter (Figures 10 through 16) with a botryoidal surface texture. These concretions are divided into two groups according to their shapes:

1) Angular and often elongate pieces that are fragmented, black, and have a platy surface. These occur throughout the sediment columns (Figure 9) of Holes 424 (Sample 1,CC; Section 3-3) and 424A (Sample $1, \mathrm{CC})$, but especially at the core catcher levels.

2) Irregularly shaped concretions similar in appearance to those found in the FAMOUS hydrothermal deposits. They are greenish in color with dark gray zones that are probably rich in manganese. These types of concretions occur in Hole 424 (Section 2-4, $10 \mathrm{~cm}$ and $30 \mathrm{~cm}$; Section 3-7, $10 \mathrm{~cm}$; and Section 3-1, $110 \mathrm{~cm}$ ), both in the foraminifer-nannofossil ooze and in the green hydrothermal deposits (Figure 9).

$\mathrm{X}$-ray diffraction data (e.g., Hoffert et al., this volume; Schrader et al., this volume) show that these concretions consist mainly of todorokite, with some birnessite.

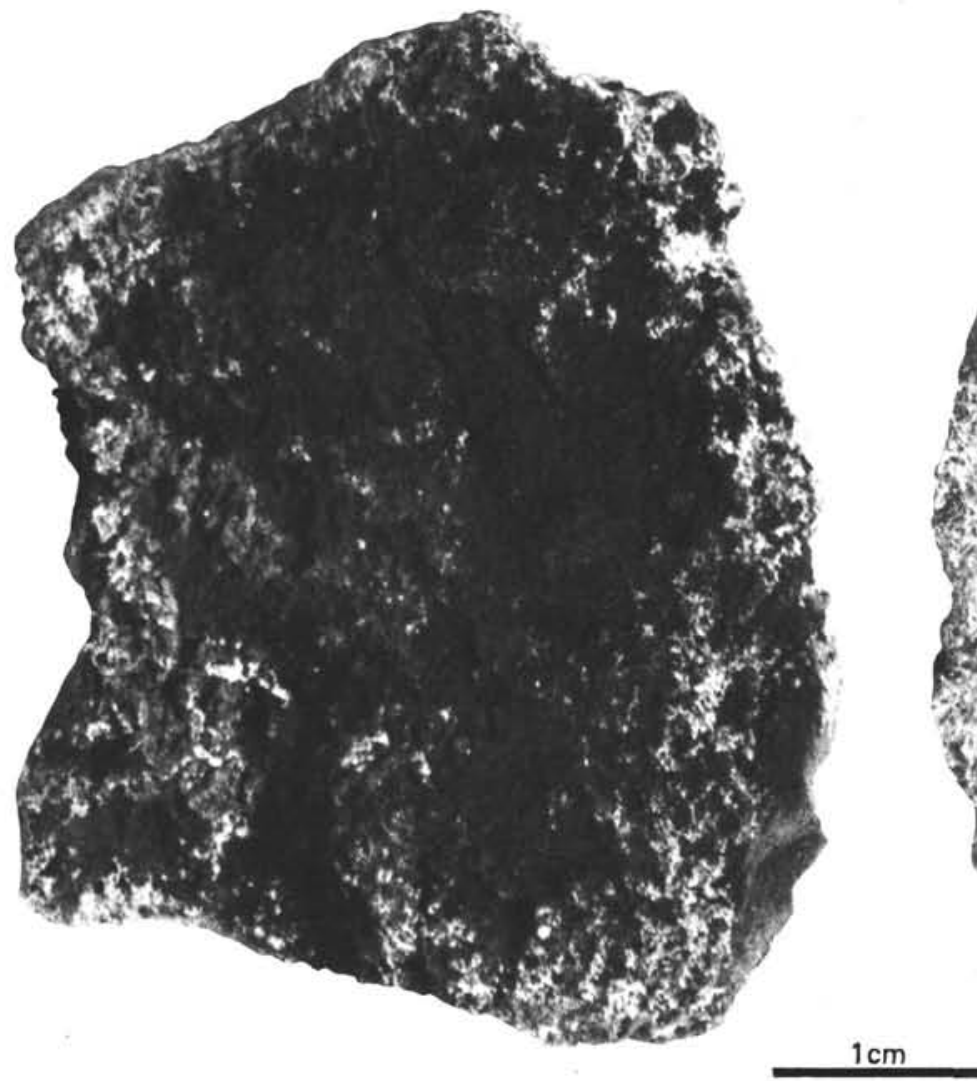

\section{Foraminifer-Nannofossil Ooze}

With the exception of the hydrothermal deposits, this is the most abundant type of sediment encountered in Holes 424, 424A, and B, and in the single core taken at the top of Hole $424 \mathrm{C}$. The colors of this sediment are as follows: grayish yellow-green (5GY7/2), dusky yellowgreen $(5 \mathrm{GY} 5 / 2)$, grayish green $(10 \mathrm{GY} 5 / 2)$, light greenish gray $(5 G Y 8 / 1)$, greenish gray $(5 G 6 / 1)$, yellowish gray $(5 Y 7 / 2)$, and moderate olive-brown (5Y4/4).

The various constituents of this type of sediment are: foraminifers (15-20\%), nannofossils $(55-70 \%)$, and clays $(15-20 \%)$. Siliceous organisms are scarce and consist of radiolarians (traces up to $5 \%$ ), diatoms, and sponge spicules. Traces of volcanic glass also were seen. The absence of foraminifer-nannofossil ooze in the uppermost cores of Holes 424 and 424A results from the placement of these holes on mounds of hydrothermal deposits. Hole 424B, however, was targeted between mounds and, as nearly as we can tell, represents the average sediment blanket for the area.

\section{Siliceous Nannofossil Ooze}

This type of sediment is found only near the top of Hole 424C (Figure 9). The different colors of Unit 3 sediments are: pale olive $(10 Y 6 / 2)$, grayish green (10GY5/2), moderate olive-brown (5Y4/4), and dusky yellow-green $(5 G Y 5 / 2)$. The major and minor consti-

Figure 10. Top and bottom views of Fe-Mn oxide chip, Sample 424-3-5, 125-130 cm. 


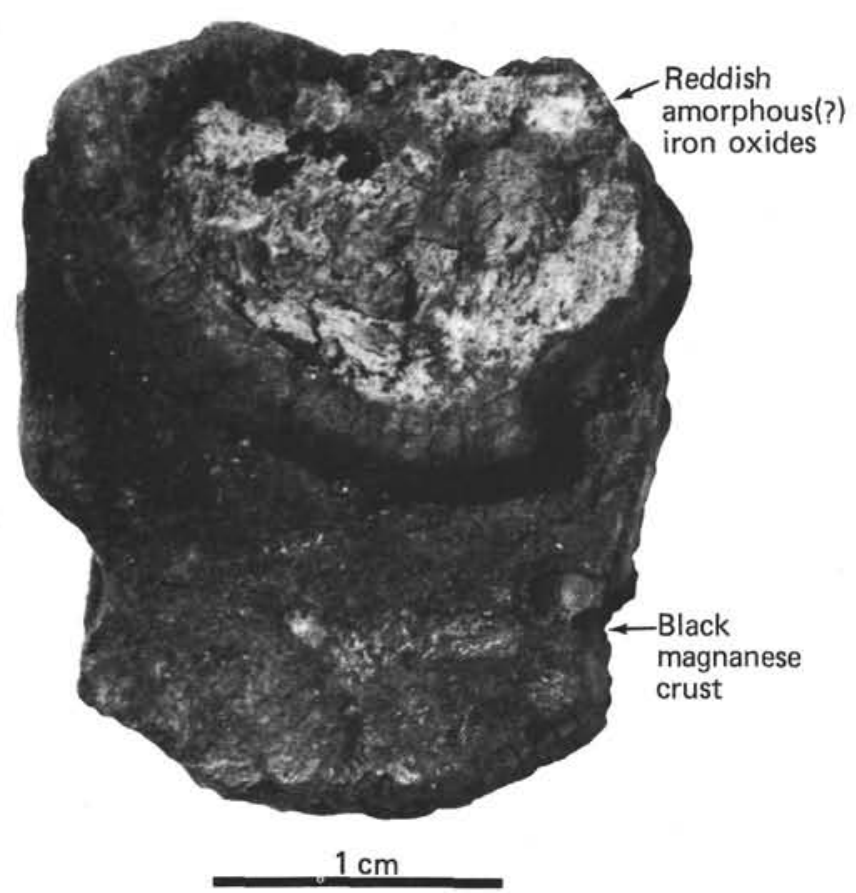

Figure 11. Fe-Mn oxide fragment Section 424-1-1, showing tubular structure with reddish amorphous (?) iron oxides encased in Mn oxides.

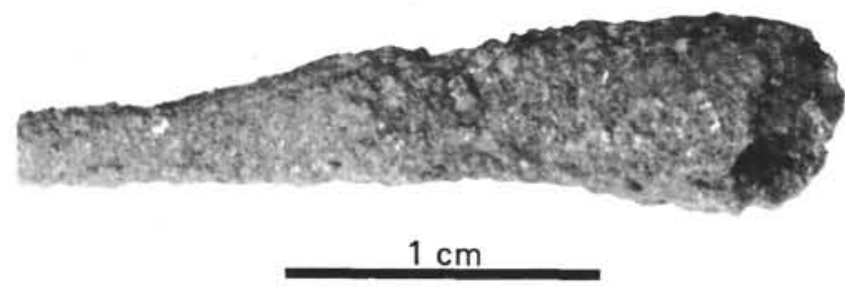

Figure 12. Tube of organism or burrow replaced by $\mathrm{Mn}$ oxides Section 424-1-1.

tuents of this unit are: nannofossils (50-65\%), foraminifers $(10-15 \%)$, clay $(10 \%)$, radiolarians $(5 \%)$, diatoms $(5-20 \%)$, and sponge spicules $(5 \%)$. The upper 10 $\mathrm{cm}$ of Section 1-1, dusky yellow-brown (10YR2/2), represents the uppermost oxidized surface sediments. Since this was only recovered at Hole $424 \mathrm{C}$, it is possible that the top few meters of siliceous nannofossil ooze was not recovered at Hole 424B, our one continuously cored hole in the typical sediment blanket in the area.

\section{Siliceous Ash-Rich Layer}

Siliceous ash was found only in Hole 424B (Section $1-2,60 \mathrm{~cm}$ ) and consists of clear volcanic shards. The index of refraction of the glass is $n=1.50$. Significant concentrations of ash were found in smear slides from samples in Hole 424, Section 4-6, 19-21 cm and Hole $424 \mathrm{~B}$, Section 4-3, 20-22 cm.

\section{Chemistry of Hydrothermal Sediment}

Chemical analyses of a green, clay-like material located in Hole 424 at Section 1-1, $90 \mathrm{~cm}$ were made us- ing the shipboard XRF. This type of green sediment is mixed with tiny granules of Mn-Fe oxide.

In order to get the cleanest possible representative samples from the green clay-like material, the following successive steps were taken:

a) Hand-picking and sorting the particles under a binocular microscope.

b) Washing the green particles with distilled water.

c) Elimination of the calcareous tests of organisms by $\mathrm{HCl}$ solution.

d) Detachment of any argillaceous material of detrital origin by the use of the ultrasonic mixer.

The result of chemical analyses shows that this material is enriched in $\mathrm{SiO}_{2}(49.6 \%)$, in $\mathrm{Fe}_{2} \mathrm{O}_{3}(24.5 \%$; total $\mathrm{Fe}$ as $\mathrm{Fe}_{2} \mathrm{O}_{3}$ ), and in $\mathrm{H}_{2} \mathrm{O}^{-}(13.9 \%)$. It is, however, depleted in $\mathrm{Al}_{2} \mathrm{O}_{3}(0.34 \%)$; the $\mathrm{Si} / \mathrm{Al}(128.5)$ and $\mathrm{Fe} / \mathrm{Mn}$ (148.1) ratios are relatively high (Table 3 ).

Similar types of deposits are described from other localities around the world. The green clay-like deposit from Site 424 is comparable to that which Bonatti et al. (1972) attributed to hydrothermal origin. The compilation of chemical data from other metalliferous deposits found in Bauer Deep (Dymond et al., 1976; DSDP Sites 319,320 , and 321) and from the FAMOUS area (Hoffert et al., 1978) is plotted in a triangular $\mathrm{Al}-\mathrm{Fe}-\mathrm{Si}$ diagram (Figure 17). This figure shows that the green clay-like deposit from Site 424 falls in the iron-enriched corner of the triangular diagram near the hydrothermal deposits from the FAMOUS area and those from the Mediterranean regions (Bonatti, et al., 1972).

For comparison, a chemical analysis of a pelagic detrital argillaceous material (Cronan, 1975) is shown in Table 4. The hydrothermal green type of clay differs from the forementioned pelagic sediment by its lower alumina content and its higher iron content (17.2\%).

\section{INTERSTITIAL WATER CHEMISTRY AND IN}

\section{SITU PORE WATER SAMPLING AT SITE 424}

At Hole 424 the in situ pore-water sampler was lowered to a sub-bottom depth of 28.5 meters. The time of sampling was 5 minutes, and upon retrieval of the sampler we found that the overflow cut-off switch had tripped as the overflow chamber was full. Further drilling revealed that the sample had, in fact, been taken no more that 2 meters above basement.

This was supplemented by two squeezed pore water samples, one of which was taken from the last $6 \mathrm{~cm}$ of sediment immediately before lowering the sampler. This permitted a direct comparison of chemical data obtained by both techniques. In addition, one squeezed sample was taken from Hole 424A and one from Hole $424 \mathrm{~B}$, both of which had sediment thicknesses similar to that of Hole 424.

The chemical analyses are presented in Table 5, and the data from all three holes are plotted against depth on Figure 18. As observed at all previous sites, very little downhole chemical gradient was observed in these sediments. The correlation between data obtained by in situ sampling and squeezing is good for $\mathrm{Ca}^{+2}, \mathrm{Mg}^{+2}$, and $\mathrm{Cl}^{-}$. However, the alkalinity values obtained from the pore waters are lower than for the in situ sample, 


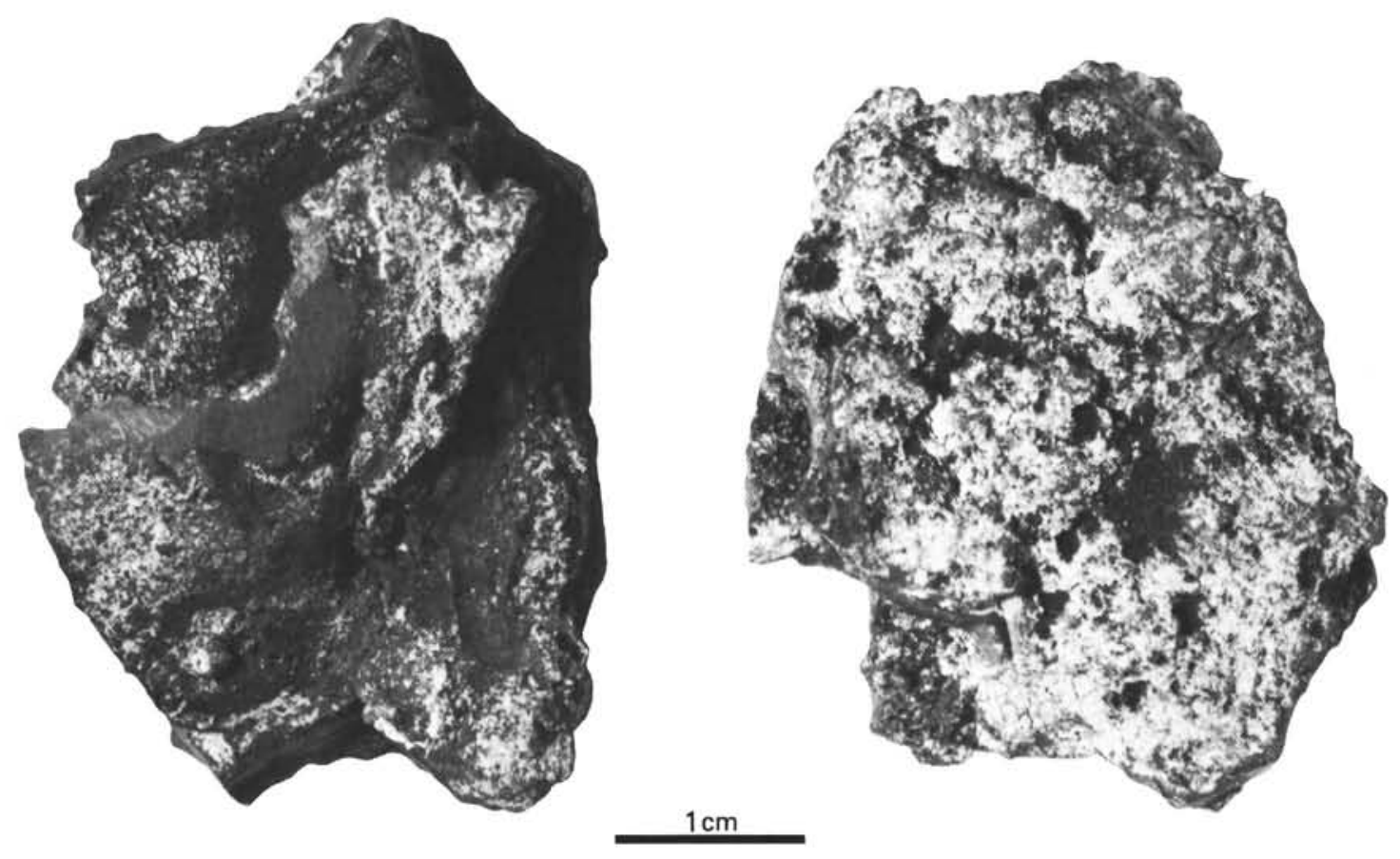

Figure 13. Top and bottom view of Fe-Mn oxide chips, Sample 424-3-5, 35-40 cm. Piece is partly coated with siliceous nannofossil ooze.

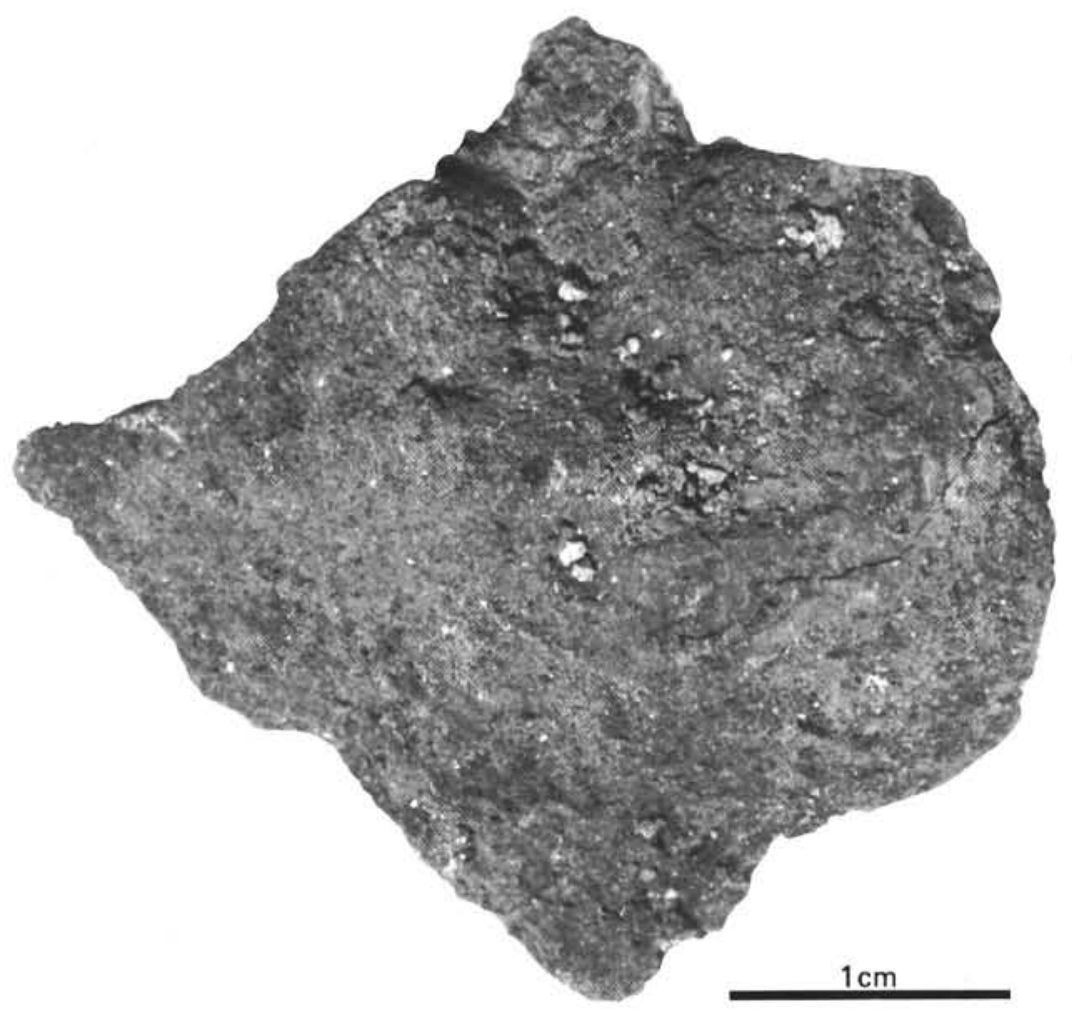

Figure 14. Mn oxide chips, Section 424-1-1. 


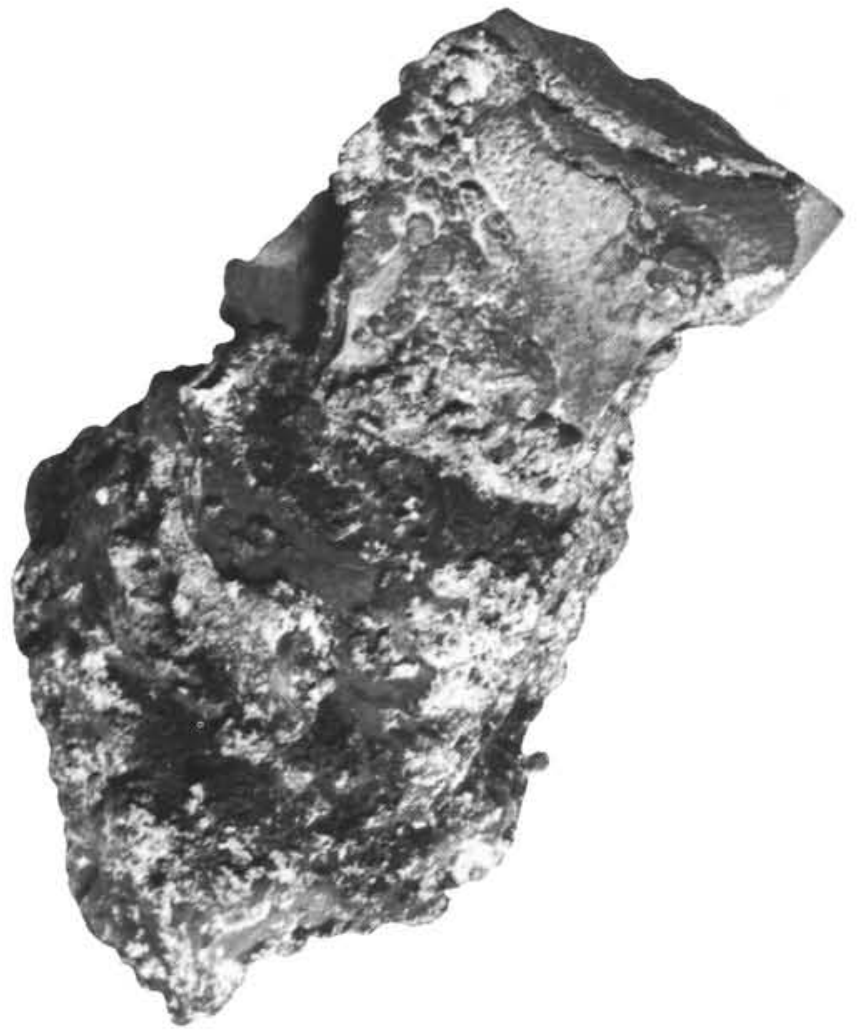

Figure 15. Mn oxide chips, Sample 424-3-4, 120-122 $\mathrm{cm}$. Knobby material is Mn oxides. Smooth material is rich in clays. Piece is $4.2 \mathrm{~cm}$ long.

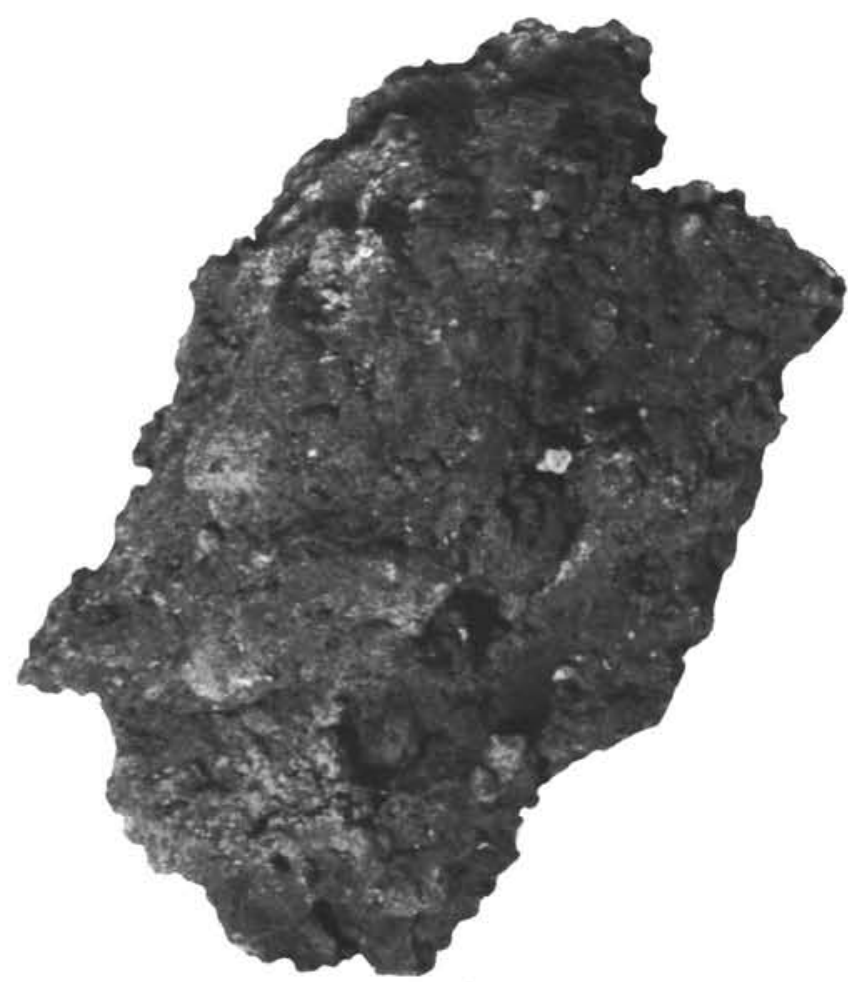

Figure 16. Earthy $\mathrm{Fe}-\mathrm{Mn}$ oxide fragment rich in clays, Sample 424-2-4, 30-33 cm. Piece is $3.6 \mathrm{~cm}$ long.
TABLE 3

XRF Analyses of Green Mud Cored at Site 424 and from Fracture Zone "A" in the FAMOUS Area ${ }^{a}$

\begin{tabular}{lcccc}
\hline & & \multicolumn{3}{c}{ FAMOUS } \\
\cline { 3 - 5 } & $\begin{array}{c}\text { DSDP } \\
\text { Site 424 }\end{array}$ & Cyp 74-26-15 & Cyp 74-26-15A & Cyp 74-26-15B \\
\hline $\mathrm{SiO}_{2}$ & 49.55 & 45.5 & 40.2 & 41.9 \\
$\mathrm{Al}_{2} \mathrm{O}_{3}$ & 0.34 & 0.2 & 0.2 & 0.2 \\
$\mathrm{Fe}_{2} \mathrm{O}_{3}$ & 24.54 & 37.9 & 32.3 & 35.1 \\
$\mathrm{MnO}$ & $\approx 0.15$ & 0.33 & 2.07 & 1.45 \\
$\mathrm{MgO}$ & 1.52 & 2.91 & 2.77 & 2.72 \\
$\mathrm{CaO}$ & 0.01 & 0.6 & 2.9 & 1.2 \\
$\mathrm{~K}_{2} \mathrm{O}$ & 2.18 & 3.23 & 3.00 & 2.80 \\
$\mathrm{TiO}_{2}$ & 0.06 & 0.02 & 0.02 & 0.02 \\
$\mathrm{H}_{2} \mathrm{O}^{-}$ & 13.9 & 6.22 & 9.13 & 7.94 \\
$\mathrm{Na}_{2} \mathrm{O}$ & $?$ & 3.23 & 3.00 & 2.80 \\
$\mathrm{Total}_{0}$ & 92.10 & 99.14 & 98.81 & 98.46 \\
$\mathrm{Si} / \mathrm{Al}$ & 128.44 & 152.79 & 134.93 & 140.64 \\
$\mathrm{Fe} / \mathrm{Mn}$ & 148.10 & 106.12 & 14.13 & 21.9 \\
\hline
\end{tabular}

${ }^{\mathrm{a}}$ Data from Hoffert et al., 1978.

which has an alkalinity close to the surface sea water. The anomalously low pore-water alkalinities, particularly for Holes 424A and B, are probably an artifact of squeezing. Hence, it appears that no diagenetic effects are occurring within these sediments or that neither type of sampling method is valid for in situ pore water.

\section{SEDIMENT LITHOLOGY, HOLE 425}

The sediment thickness at Hole 425 is about 81.5 meters (Figure 9). The sediment column was spot-cored and the uncored intervals are located at 15.0-24.5 meters, 34.0-43.5 meters, and 53.0-62.5 meters. From visual core descriptions and smear slide observations, the sediment column consists of two major sediment types: foraminifer-nannofossil ooze and siliceous nannofossil ooze. Siliceous ash was found in a sample from Core 2, Section 5, 19-21 cm.

\section{Foraminifer-Nannofossil Ooze}

This type of sediment occurs in Cores 1, 2, 3, and 5, and the lowest portion of Core 6 , closest to the basaltic basement. Colors vary as follows: greenish gray (5GY6/ $1)$, grayish green $(10 \mathrm{GY} 5 / 2)$, dusky yellow-green (5GY5/ $2)$, and pale olive $(10 \mathrm{Y} 6 / 2)$. The main constituents are: nannofossils $(45-65 \%)$, foraminifers $(10-25 \%)$, clay $(10-30 \%)$, radiolarians (trace to $5 \%$ ), sponge spicules (trace to $5 \%$ ), diatoms (trace to $10 \%$ ), and brown volcanic glass (trace). Streaks, lamellae, and patches of pyritic material also are scattered throughout the unit. The sediments are moderately to intensely disturbed.

\section{Siliceous Nannofossil Ooze}

This type of sediment is found in the middle section of the sediment column (Core 3, Sections 3 through 6; Core 4, Sections 1 through 4). Colors are greenish gray $(5 G Y 6 / 1)$ and grayish yellow-green $(5 G Y 7 / 2)$. The major constituents are: nannofossils $(40-50 \%)$, foraminifers $(15-20 \%)$, clay $(10 \%)$, radiolarians $(10 \%)$, diatoms $(10-15 \%)$, sponge spicules $(5-10 \%)$, brown glass (trace), and pyritic material (trace). 

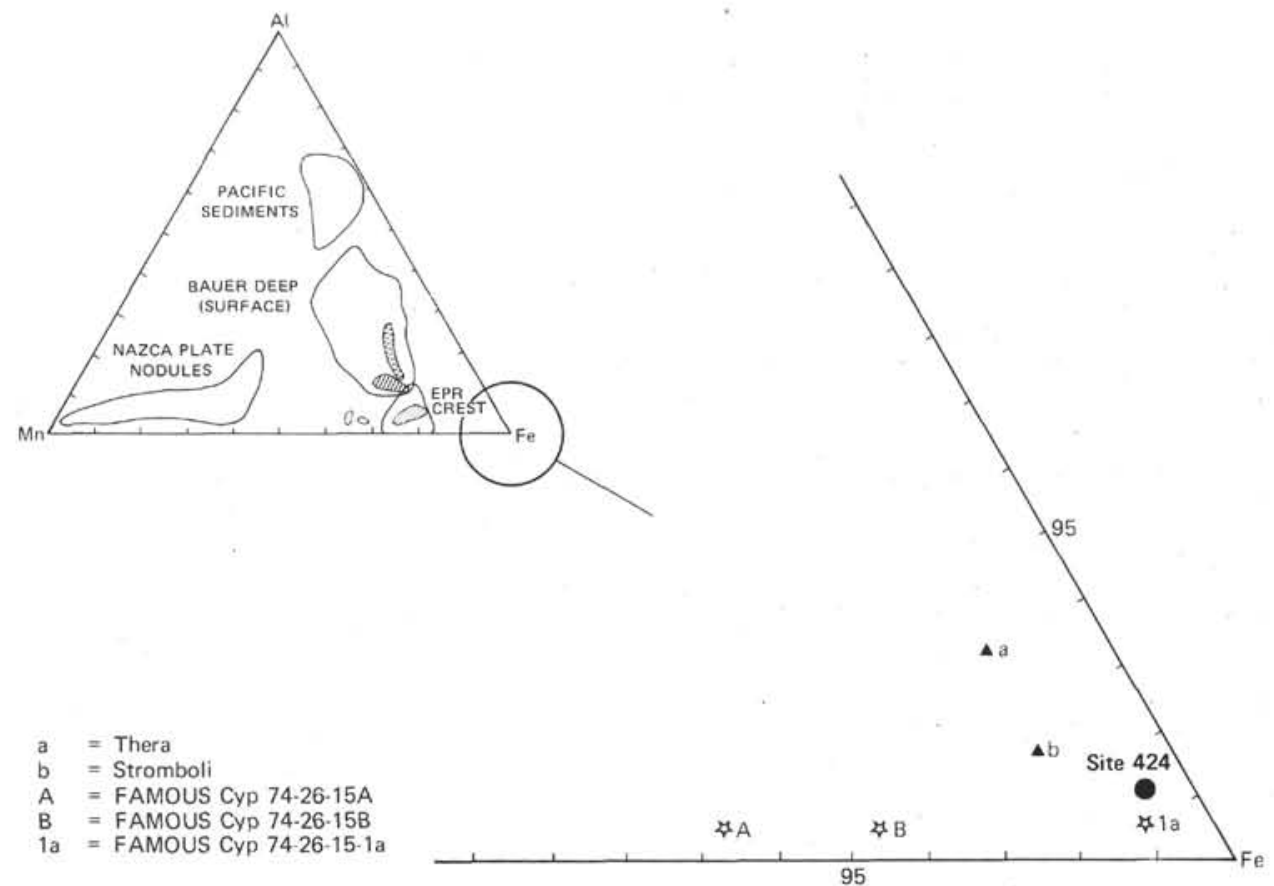

Figure 17. Ternary plot of Fe, Mn, and Al showing location of Site 424 hydrothermal green mud (large filled circle) in comparison with fields for Pacific pelagic clay, Bauer deep-surface sediments, and Nazca Plate Mn nodules from Dymond et al. (1976). Metalliferous deposits from Thera (a) and Stromboli (b) are from. Bonatti et al. (1972), FAMOUS area deposits (A, B, la) are from Hoffert et al. (1978).

TABLE 4

Abundances of Elements in Hydrothermal Deposits and Average Pelagic Clay

\begin{tabular}{lccccc}
\hline & Site 424 & A & B & C & D \\
\hline $\mathrm{Si}$ & 23.2 & 11.6 & 7.9 & 5.8 & 25.0 \\
$\mathrm{Al}$ & 0.18 & 1.2 & 0.4 & $<0.5$ & 9.34 \\
$\mathrm{Fe}$ & 17.18 & 35.0 & 28.0 & 31.1 & 5.06 \\
$\mathrm{Mn}$ & $\approx 0.116$ & 0.6 & 9.2 & 0.58 & 0.478 \\
$\mathrm{Si} / \mathrm{Al}$ & 128.44 & 9.6 & 19.75 & 11.6 & 2.67 \\
$\mathrm{Fe} / \mathrm{Mn}$ & 148.10 & 58.33 & 3.04 & 53.62 & 10.5 \\
\hline
\end{tabular}

Note: $A=$ Thera (Bonatti et al., 1972). $B=$ Stromboli (Bonatti et al., 1972). C = Seamount Amph P2 on the East Pacific Rise (Bonatti and Joensuu, 1966). $\mathrm{D}=$ Average pelagic clay (Cronan, 1975).

TABLE 5

Chemical Data for Pore Waters, Site 424

\begin{tabular}{|c|c|c|c|c|c|c|c|}
\hline Sample & $\begin{array}{l}\text { Sub-Bottom } \\
\text { Depth } \\
\text { (m) }\end{array}$ & $p \mathrm{H}$ & $\begin{array}{l}\text { Alkalinity } \\
\text { (meq } / \mathrm{kg} \text { ) }\end{array}$ & $\begin{array}{c}\text { Salinity } \\
\left(\% \%_{0}\right)\end{array}$ & $\underset{(m i n o l e s / 1)}{\mathrm{Ca}^{+2}}$ & $\underset{\text { (mmoles } / 1)}{\mathrm{Mg}^{+2}}$ & $\underset{(\%)}{\mathrm{Cl}^{-}}$ \\
\hline $\begin{array}{l}\text { IAPSO Std. } \\
\text { seawater }\end{array}$ & - & 7.855 & 2.387 & 36.0 & 10.550 & $\$ 3.990$ & 19.375 \\
\hline $\begin{array}{l}\text { Surface } \\
\text { seawater }\end{array}$ & - & 7.848 & 2.309 & 36.3 & 10.529 & 54.011 & 19.409 \\
\hline $\begin{array}{l}\text { Hole } 424 \\
\text { Section } 3-6 \\
\text { In situ sample } \\
\text { Section 4-4 }\end{array}$ & $\begin{array}{l}28.45 \\
28.5 \\
34.5\end{array}$ & $\begin{array}{l}7.758 \\
7.847 \\
7.586\end{array}$ & $\begin{array}{l}1.998 \\
2.418 \\
2.113\end{array}$ & $\begin{array}{l}36.0 \\
35.2 \\
35.2\end{array}$ & $\begin{array}{l}11.532 \\
12.280 \\
11.895\end{array}$ & $\begin{array}{l}50.530 \\
50.785 \\
51.465\end{array}$ & $\begin{array}{l}19.341 \\
18.937 \\
19.274\end{array}$ \\
\hline $\begin{array}{l}\text { Hole 424A } \\
\text { Section } 2-2\end{array}$ & 17.95 & 7.688 & 1.797 & 35.8 & 11.490 & $\$ 1.457$ & 19.274 \\
\hline $\begin{array}{l}\text { Hole 424B } \\
\text { Section 3-4 }\end{array}$ & 19.0 & 8.074 & 1.080 & 35.8 & 10.849 & 50.918 & 19.207 \\
\hline
\end{tabular}

\section{SQUEEZED PORE WATER CHEMISTRY, HOLE 425}

Two squeezed pore-water samples, from sub-bottom depths of 26.5 and 64.5 meters, plus a surface sea-water sample were taken from Hole 425 . The sediments at this site were soupy and deformed, and consisted of layers containing hydrotroilite. This suggested that some reactions due to reducing conditions were occurring in these sediments. There was also siliceous ash at Section 425-2-4 (19-21 cm).

Table 6 shows the results of chemical analyses of the pore waters and surface sea water. There is some question as to the accuracy of the salinity data, because the IAPSO standard sea water should have a value of $35.2 \%$ and not $36.0 \%$. This indicates that either the refractometer was out of adjustment, in which case the sample values are incorrect, or the standard was contaminated or had evaporated slightly.

On the basis of two analyses, it was not possible to determine the reactions that had taken place in these sediments. However, there were chemical variations in the fluid. The $\mathrm{Ca}^{+2}$ content increases, while the concentration of $\mathrm{Mg}^{+2}$ and the alkalinity decrease. The changes in the $\mathrm{Mg}$ and $\mathrm{Ca}$ contents do not comprise the 1:1 molar exchange that would be expected from ion exchange in carbonates, the change in $\mathrm{Ca}^{+2}$ content being larger than that in $\mathrm{Mg}^{+2}$. The reason for this is not known, but the alteration of trace amounts of volcanic 


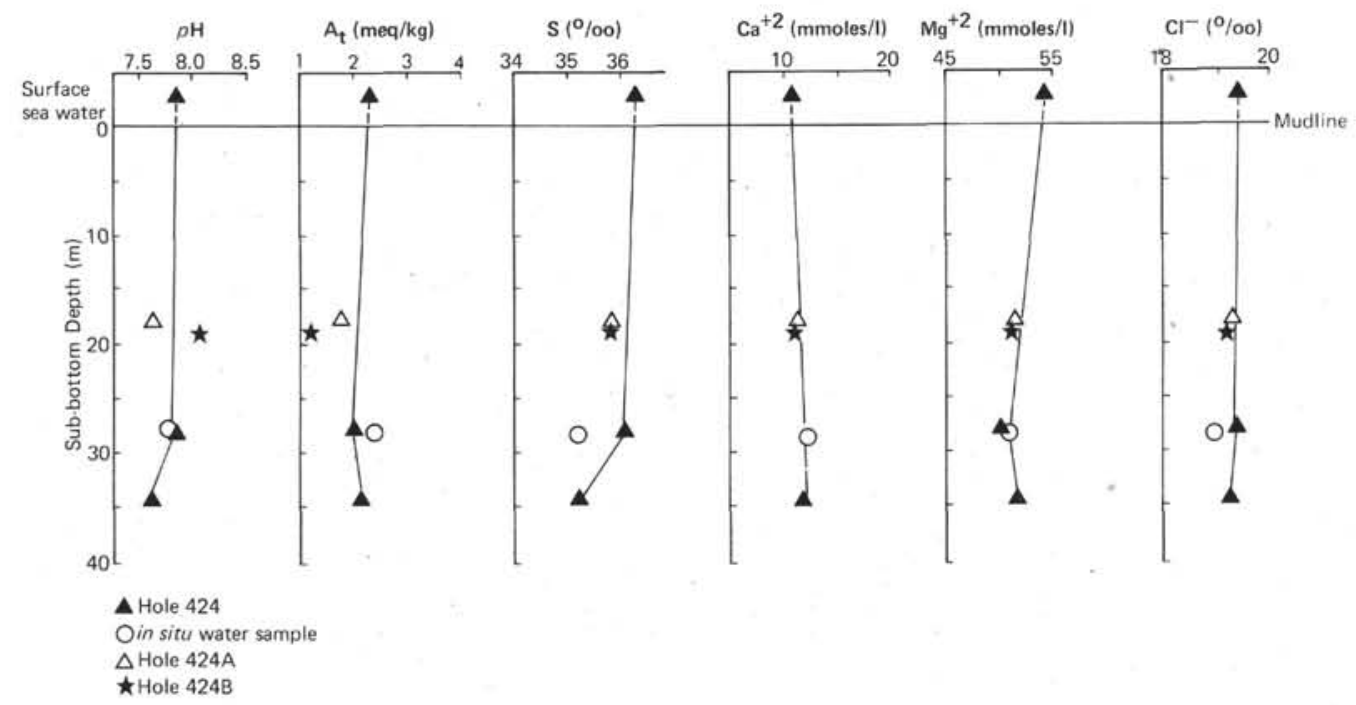

Figure 18. Chemistry of interstitial waters versus depth, Site 424.

TABLE 6

Chemical Data for Pore Waters, Hole 425

\begin{tabular}{lccccccc}
\hline \multicolumn{1}{c}{ Sample } & $\begin{array}{c}\text { Sub-Bottom } \\
\text { Depth } \\
(\mathrm{m})\end{array}$ & $\mathrm{pH}$ & $\begin{array}{c}\text { Alkalinity } \\
\text { (meq/kg) }\end{array}$ & $\begin{array}{c}\text { Salinity } \\
(\% / \%)\end{array}$ & $\begin{array}{c}\mathrm{Ca}^{+2} \\
(\text { mmoles/1) }\end{array}$ & $\begin{array}{c}\mathrm{Mg}^{+2} \\
(\mathrm{mmmoles} / 1)\end{array}$ & $\begin{array}{c}\mathrm{Cr}^{-} \\
(\%)\end{array}$ \\
\hline $\begin{array}{l}\text { IAPSO Standard } \\
\text { Seawater }\end{array}$ & - & 7.886 & 2.380 & 36.0 & 10.550 & 53.990 & 19.375 \\
Surface seawater & - & 8.113 & 2.199 & 34.1 & 9.888 & 51.113 & 18.302 \\
Section 3-2 & 26.5 & 7.602 & 2.843 & 36.0 & 11.233 & 50.948 & 19.241 \\
Section 5-2 & 64.5 & 7.465 & 2.031 & 36.8 & 15.355 & 48.891 & 19.643 \\
\hline
\end{tabular}

glass in these sediments could provide additional fluxes of both ions. The slight increase in $\mathrm{Cl}^{-}$and the decrease in alkalinity are also consistent with the contention that reactions were occurring within the sediment at the time it was cored, particularly as volcanic material was present.

\section{MICROPALEONTOLOGY OF GALAPAGOS SITES}

Galapagos Sites 424 and 425 contain Quaternary assemblages that are micropaleontologically distinct from the Siqueiros sites. Planktonic foraminifers, coccoliths, diatoms, and radiolarians, are all more diverse and better preserved at the Galapagos sites. Only opal phytoliths are poorer, owing to unfavorable wind and current directions relative to the nearest land. The imprint of the Peru Current is evident at Site $\mathbf{4 2 5}$ in the great abundances of silicoflagellates and elongate diatoms which require waters substantially enriched through upwelling. As a result, Site 425 is a useful reference for regional correlation. Only the skip-coring program in the upper 80 meters prevented Site 425 from being the best reference section in the area. Correlation of zonal schemes for the various microfossil groups are shown on Figures 19 through 23 .

\section{Planktonic Foraminifers}

Tropical foraminifer assemblages at the Galapagos sites are not affected by selective dissolution. The presence of Globorotalia inflata and Globigerina bulloides in some samples from Core 3 , Hole 425 , indicates an interval of lowered temperatures in surface waters (Krasheninnikov, planktonic foraminifer chapter, this volume).

\section{Coccoliths}

Coccoliths are well preserved and diverse in the Quaternary sediment of Sites 424 and 425 . Reduced abundances of Coccolithus pelagicus upward from Core 6 to 5 at Hole 425 indicate an early Quaternary warming trend that is also shown by the coincident reduction of the cool-water silicoflagellate Distephanus speculum speculum. Higher in the section another warming trend is suggested by an increase in the numbers of Gephyrocapsa oceanica and $G$. omega having low-angle bars in Core 3, Hole 425, (Bukry, coccolith chapter, this volume). This coccolith evidence is contrary to the cooling trend interpreted from the foraminifers of Hole 425 .

\section{Radiolarians}

Radiolarians are abundant and well preserved in Cores 1 through 5 at Hole 425 but are poorly preserved in Core 6, except for the core catcher sample. Collosphaera invaginata occurs in the uppermost sediments only at Holes 424 and $424 \mathrm{C}$, but this may be a regional phenomenon as this species was not observed by Dinkelman (1973) in other eastern equatorial Pacific DSDP sites. The radiolarian age of the basal sediments (Plagiacantha hofferti Zone, 1.3-1.6 Ma) is somewhat younger than the age based on other microfossils (1.6-1.8 Ma).

Radiolarians are preserved only sporadically in the recovery at Site 424 . The occurrence of Collosphaera tuberosa in the uppermost sediments of Holes 424, $424 \mathrm{~B}$, and $\mathrm{C}$ indicates that normal pelagic sedimentation recommenced within the past 200,000 years. The sea floor at Hole $424 \mathrm{~A}$ is covered with a manganese crust and appears to be a nondepositional locality. The absence of $C$. tuberosa in the uppermost sediments at Hole 424A may be a dissolution effect. Basal sediments in Holes 424 and 424B belong to the Pseudocubus war- 


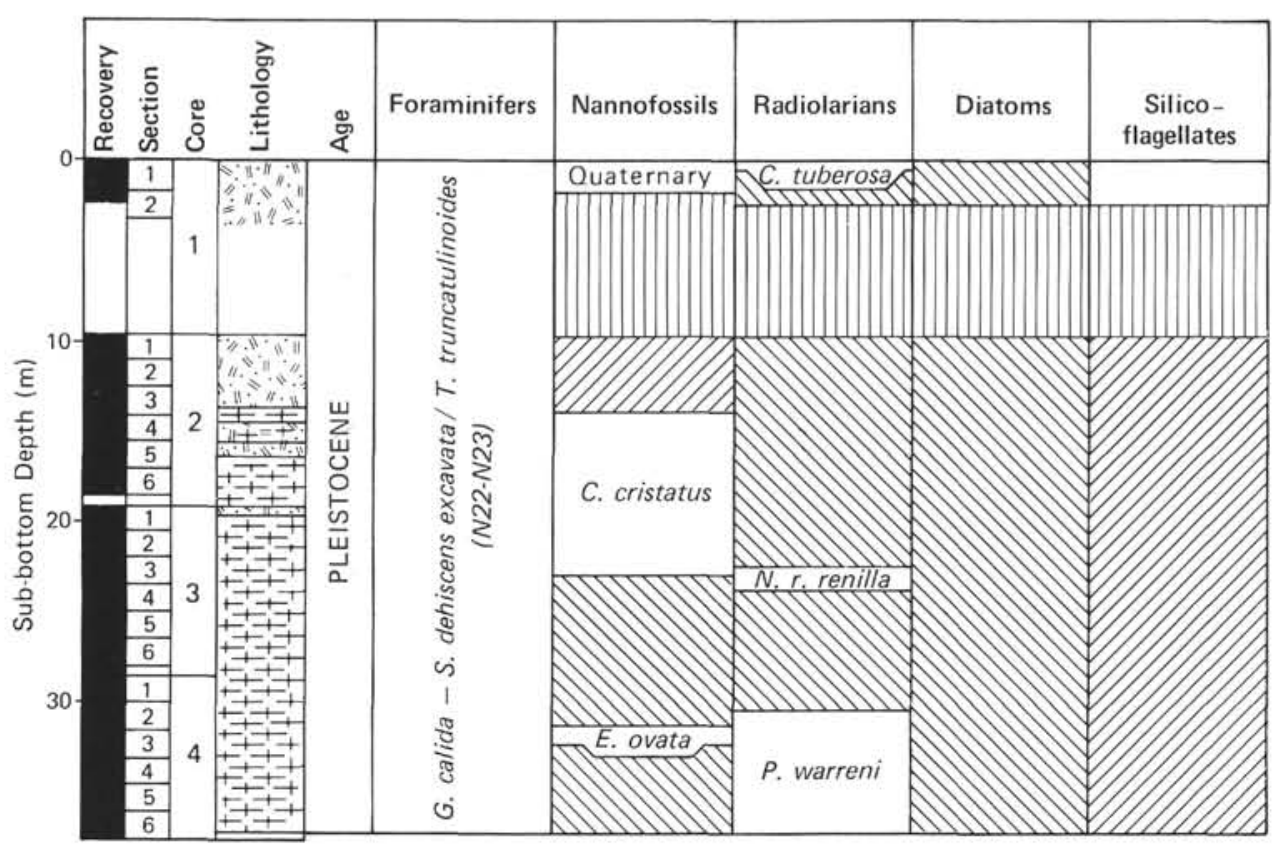

Figure 19. Microfossil zonal correlations, Hole 424 (symbols as in Chapter 9, Figure 21).

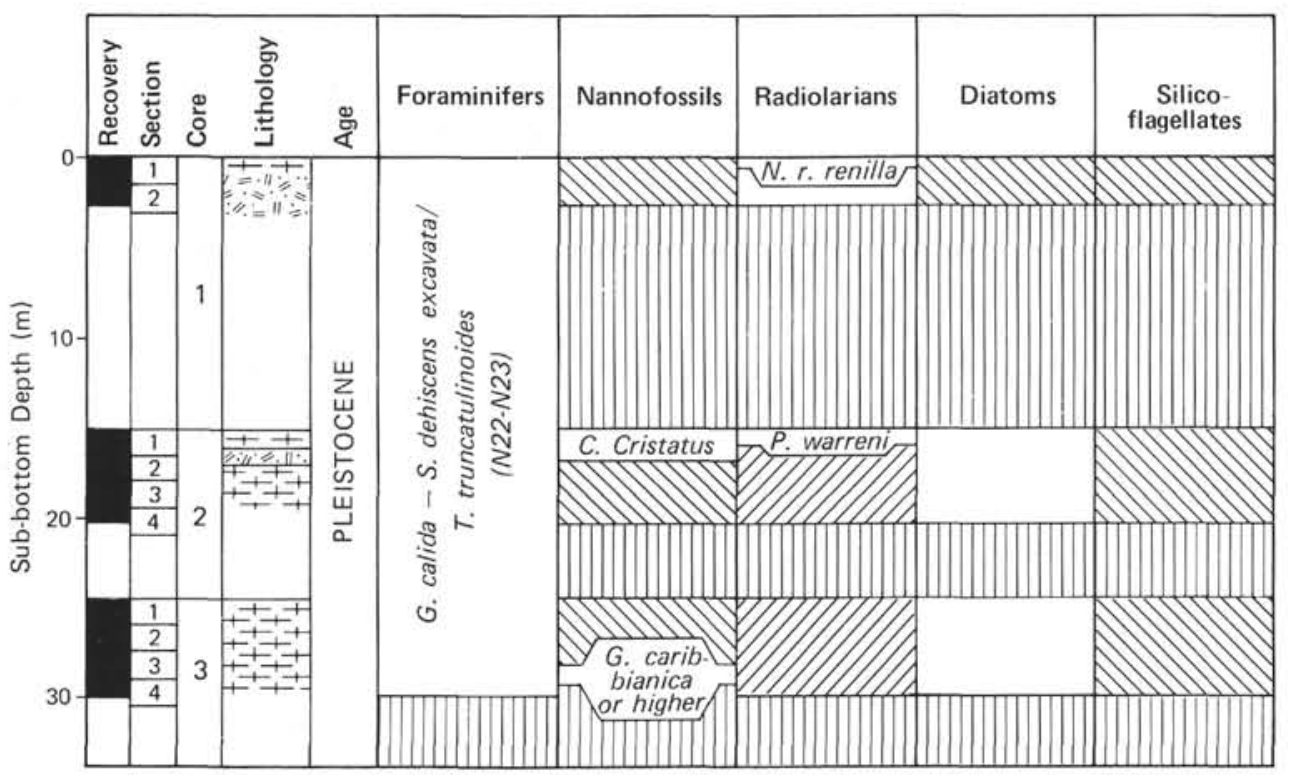

Figure 20. Microfossil zonal correlations, Hole 424A (symbols as in Chapter 9, Figure 21).

reni Zone, which provides a maximum age of 0.65 m.y. for these sediments. Radiolarian ages for the initiation of hydrothermal deposition in Holes 424 and $424 \mathrm{~A}$ are not consistent. A single occurrence of well-preserved radiolarians in the top of Core 2 of Hole $424 \mathrm{~A}$ indicates that hydrothermal deposition began after $0.4 \mathrm{Ma}$, but the radiolarian age of Section 424-3-3 indicates that hydrothermal activity began before this data. This disparity may be the result of mechanical drilling disturbances, however.

\section{Diatoms}

Tropical diatom assemblages in sediments at Site 424 and Hole 425 are all Quaternary. Diatoms are more abundant and preservation is best at Hole 425, where a nearly complete Quaternary section is present. Common Thalassiothrix longissima in the assemblages probably reflects upwelling associated with the distal end of the Peru Current. Reworked upper Miocene diatoms, including Thalassiosira miocenica, $T$. convexa var. aspinosa, and Nitzschia miocenica, occur in the lower parts of the section at Site 424 and Hole 425 (Barron, diatom chapter, this volume).

\section{Silicoflagellates}

Silicoflagellates are diverse and abundant at Hole 425 , showing affinity with the Peru Current assemblages of DSDP Legs 16 and 34 to the south. The deep- 


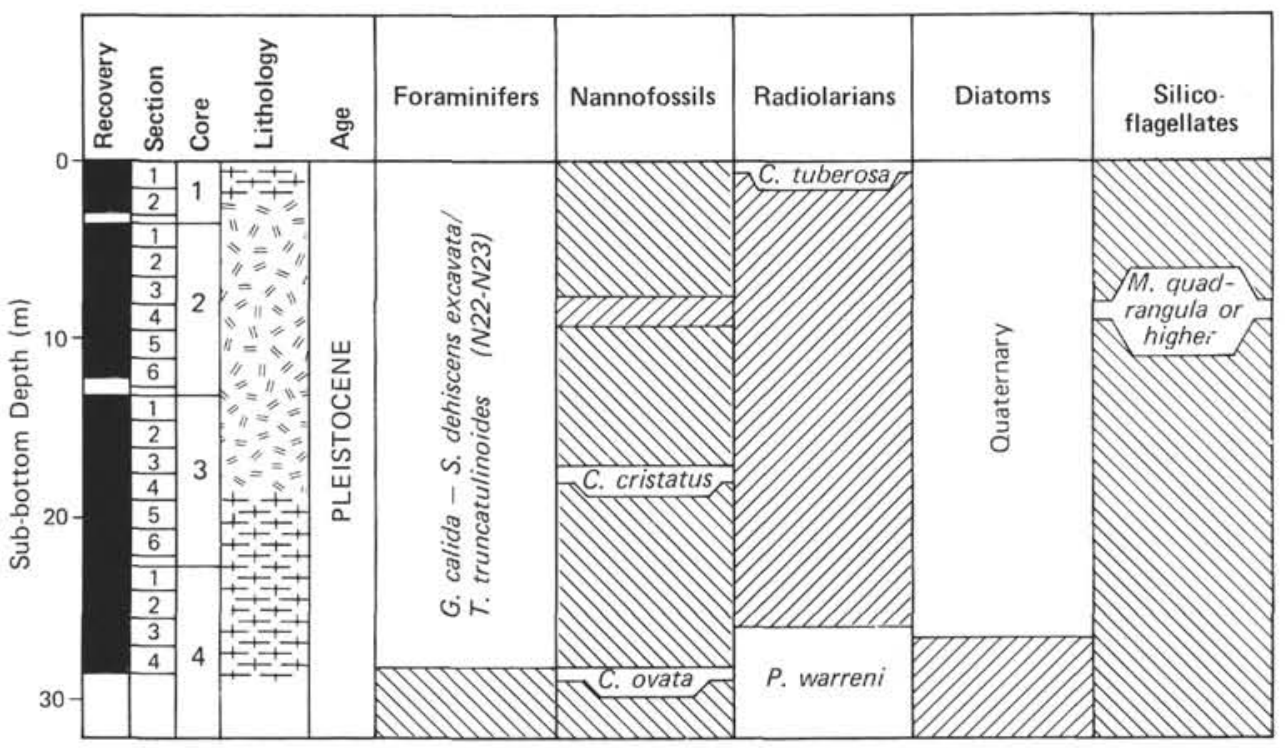

Figure 21. Microfossil zonal correlations, Hole 424B (symbols as in Chapter 9, Figure 21).

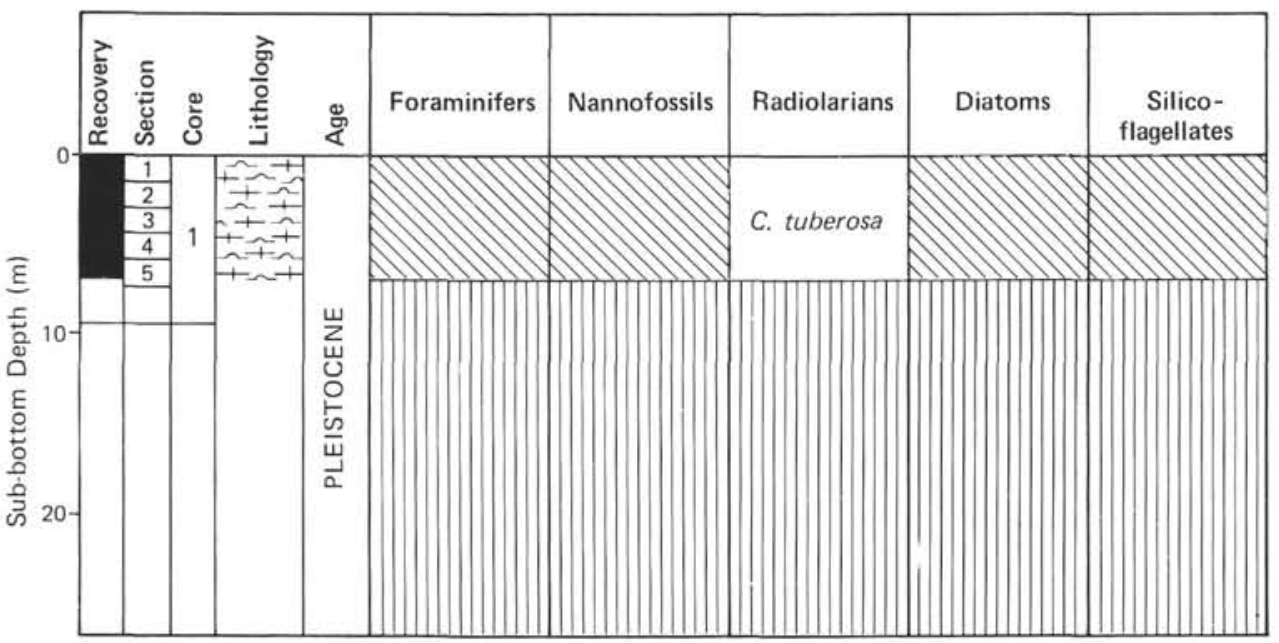

Figure 22. Microfossil zonal correlations, Hole 424C (symbols as in Chapter 9, Figure 21).

est sediment from Hole 425 contain Dictyocha perlaevis flexatella and $D$. perlaevis ornata, which are guide species for the Pliocene/Pleistocene boundary interval in the Atlantic Ocean (Bukry, silicoflagellate chapter, this volume). Silicoflagellates are sparse or absent at Site 424 .

\section{Opal Phytoliths}

Opal phytoliths are extremely sparse at Site 424 and Hole 425 and show no significant variations (Bukry, opal phytolith chapter, this volume).

\section{BASAL SEDIMENT AGES AND RATES OF SEDIMENT ACCUMULATION FOR THE GALAPAGOS SITES}

As was the case for the Siqueiros sites, we have used the revised zonal boundary ages, based on the recovery from Site 420, for our determinations of basal sediment ages and rates of sediment accumulation for the Galapagos sites.

\section{Holes 424, 424A, B and C}

Rates of sediment accumulation for these holes have not been plotted because of inadequate control. Radiolarians preserved in the basal sediments of Holes 424 and 424B belong to the Pseudocubus warreni Zone $(0.38-0.68 \mathrm{Ma})$, which is in approximate agreement with the basalt age estimate (Table 7). Average rates of sediment accumulation based on these fossil ages range from 47.0 to 98.7 meters $/ 10^{6}$ years.

\section{Hole 425}

Time versus depth sub-bottom at Hole 425 has been plotted in Figure 24. The available data indicate that the accumulation rate during the most recent 0.4 m.y. ( $86 \mathrm{~m}$ /m.y.) has been higher than that of the lower portion of the section $(39 \mathrm{~m} / \mathrm{m} . \mathrm{y}$.$) . There is considerable scat-$ ter in the microfossil data for the lower 15 meters at Hole 425 , and this section may contain a diastem of as much as 0.7 m.y. Because of this lack of agreement in 


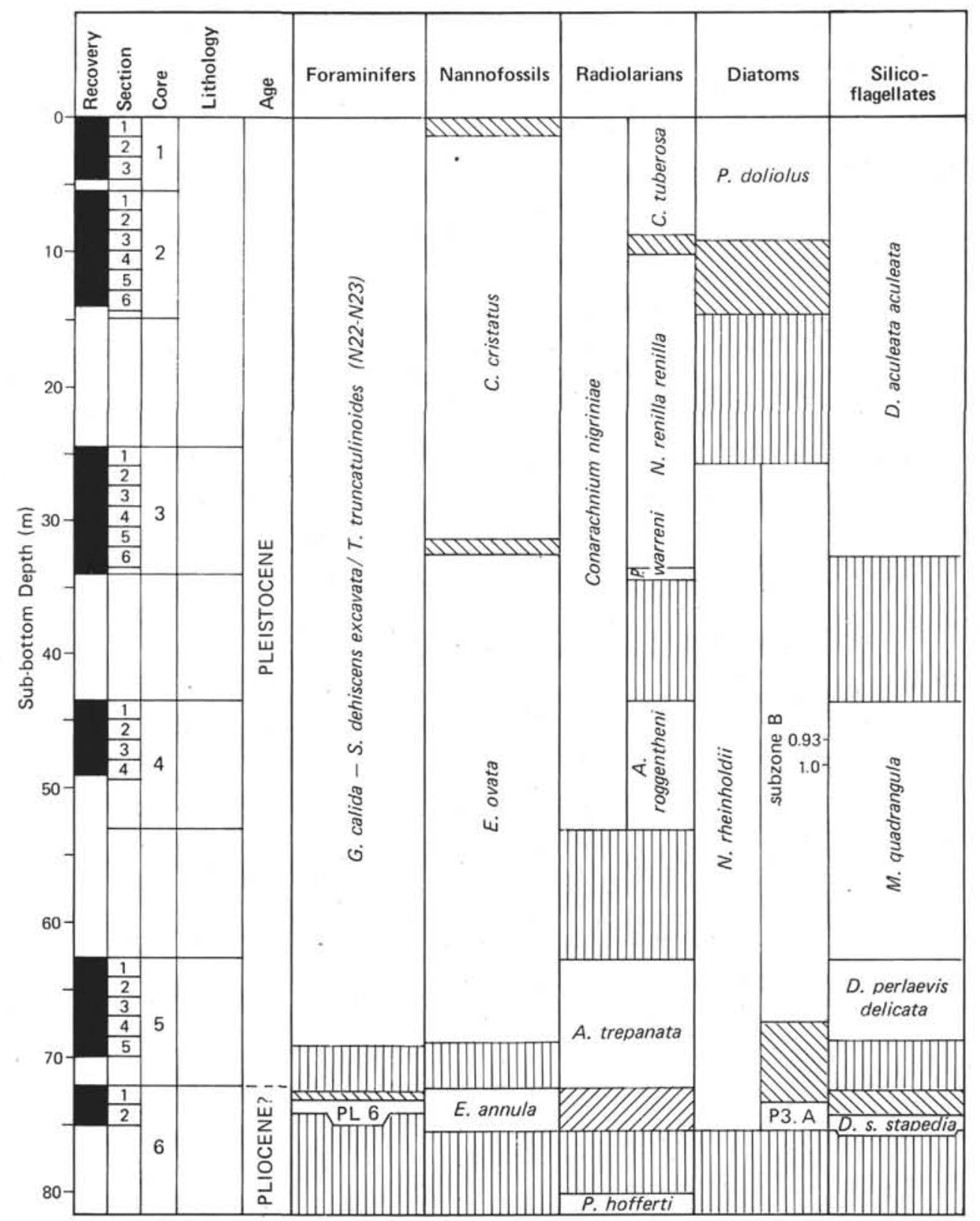

Figure 23. Microfossil zonal correlations, Hole 425 (symbols as in Chapter 9, Figure 21).

TABLE 7

Micropaleontologic Age Estimates for Basalt Fossil Assemblages or Extrapolated Micropaleontologic Age Based on Sedimentation Curves for the Galapagos Sites Compared with Magnetic Age Estimates for Basement

\begin{tabular}{|c|c|c|c|c|c|c|}
\hline Hole & $\begin{array}{l}\text { Depth Sub- } \\
\text { Bottom to } \\
\text { Basement } \\
\text { (m) }\end{array}$ & $\begin{array}{l}\text { Basal } \\
\text { Sediments } \\
\text { Sampled }\end{array}$ & $\begin{array}{l}\text { Basal Sediment Age } \\
\text { Determined by Micro- } \\
\text { fossils or Extrapolation }\end{array}$ & $\begin{array}{l}\text { Fossil Age } \\
\text { Estimate } \\
\left(\times 10^{6} \mathrm{y} .\right)\end{array}$ & $\begin{array}{c}\text { Magnetic Age } \\
\text { Estimate of } \\
\text { Basalt } \\
\left(\times 10^{6} \mathrm{y} .\right)\end{array}$ & $\begin{array}{l}\text { Average Rate of } \\
\text { Sediment } \\
\text { Accumulation } \\
\left(\mathrm{m} / 10^{6} \mathrm{y} .\right)\end{array}$ \\
\hline 424 & 38.5 & yes & Coccoliths + Radiolarians & $0.38-0.68$ & $0.60-0.62$ & $55.1-98.7$ \\
\hline $424 \mathrm{~A}$ & 33.9 & yes & Indeterminate & - & $0.60-0.62$ & $49.8-89.2$ \\
\hline $424 B$ & 32 & yes & Coccoliths + Radiolarians & $0.38-0.68$ & $0.60-0.62$ & $47.0-84.2$ \\
\hline $424 \mathrm{C}$ & 26.7 & no & Indeterminate & - & $0.60-0.62$ & - \\
\hline 425 & 81.5 & yes & Extrapolation & 1.74 & 1.85 & 46.8 \\
\hline
\end{tabular}




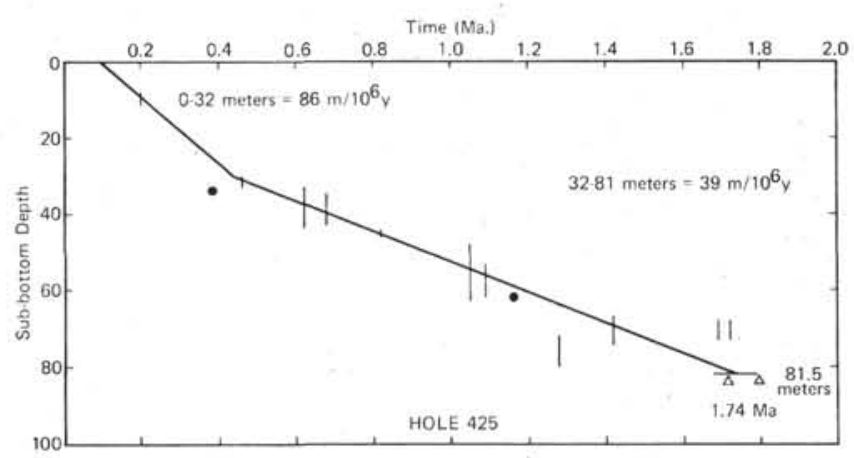

Figure 24. Microfossil age versus depth, Hole 425. Slope of segments of line gives sedimentation rates as indicated on the figure.

the paleontological indices, the basal sediment age estimate has been extrapolated from the rate curve to be 1.74 $\mathrm{Ma}$, which is in reasonable agreement with the basalt age estimate (Table 7). The average rate of sediment accumulation $(46.8 \mathrm{~m} / \mathrm{m} . \mathrm{y}$.$) , is in close agree-$ ment with these values at Site 424 . The sediment accumulation rates at both Site 424 and Hole 425 are approximately three times greater than the rate at DSDP Site 158 (located $4^{\circ}$ to the north) and must reflect the greater fertility and elevated lysocline of the overlying water column.

\section{IGNEOUS BASEMENT LITHOLOGY, SITE 424}

The basalt recovered in Hole 424 is massive, contains few glassy margins, and is texturally aphyric to sparsely phyric; plagioclase is the dominant phenocryst observed. Basalts in the other holes are fine-grained, contain more glass selvages, and appear to be portions of pillows or sheet flows. Vesicles occupy about 1 to 2 volume per cent of the rocks, most of which are lined with clays that are pale green or amber clay in color. Alteration is minor, confined to dark gray oxidative alteration rinds on some pieces, and, rarely, infilling of vesicles with green clays and traces of pyrite. Recovery data for basement in all four holes are given in Table 8 .

\section{Hole 424}

Examination of 17 thin sections revealed large ranges in crystal size, crystal morphologies, and in the degree of crystallinity (Table 9). Despite these textural variations, shipboard analyses showed chemical compositions similar throughout to those of ferrobasalt (see

TABLE 8

Basement Penetration and Recovery Data, Site 424

\begin{tabular}{lrrrr}
\hline \multicolumn{1}{c}{ Hole: } & \multicolumn{1}{c}{424} & 424A & 424B & \multicolumn{1}{c}{ 424C } \\
\hline $\begin{array}{l}\text { Depth to basement (m) } \\
\text { Total penetration (m) }\end{array}$ & 2740.5 & 2742.0 & 2742.0 & 2738.0 \\
Total basalt core re- & 45.0 & 5.0 & 14.5 & 3.0 \\
$\begin{array}{l}\text { covered (measured in } \\
\text { spaced core liner) (m) }\end{array}$ & 8.45 & $0.10^{\mathrm{a}}$ & 3.75 & 1.35 \\
\hline
\end{tabular}

additional slumped material of $0.51 \mathrm{~cm}$ also recovered, but not cored.
TABLE 9

Modal Analyses of Basalts, Site 424 (1000 counts)

\begin{tabular}{|c|c|c|c|c|c|c|c|}
\hline $\begin{array}{c}\text { Sumple } \\
\text { (Interval in cm) }\end{array}$ & Olivine & Clinopyrosene & Plagioclase & Opsiques & Glass & Vesicles & $\begin{array}{l}\text { Alteration } \\
\text { Minerals }\end{array}$ \\
\hline \multicolumn{8}{|l|}{ Hole 424} \\
\hline 4-6. $112-116$ & 0.0 & 25.5 & 40.7 & 11.9 & 22.2 & 0.2 & 0.5 \\
\hline $5-1.131-134$ & 0.3 & 42.4 & 30.3 & 9.0 & 14.5 & 0.8 & 3.6 \\
\hline $5-2.90-93$ & 0.0 & 38.0 & 40.6 & 6.4 & 13.0 & 2.8 & 0.0 \\
\hline $6-1.29-32$ & 0.0 & 31.6 & 40.7 & 10.2 & 17.7 & 0.0 & 0.0 \\
\hline $6-1.138-140$ & 0.0 & 34.3 & 39.1 & 6.9 & 18.5 & 0.7 & 0.1 \\
\hline $6 \cdot 2,107-109$ & 0.0 & 35.5 & 44.8 & 8.5 & 10.0 & 0.8 & 0.4 \\
\hline $6 \cdot 3.21-24$ & 0.3 & 28.4 & 47.2 & 10.2 & 13.5 & 0.6 & 0.0 \\
\hline \multicolumn{8}{|l|}{ Hole 424B } \\
\hline $5 \cdot 1,51-54$ & trace & 15.4 & 43.0 & 8.0 & 33.0 & 1.0 & 0.0 \\
\hline $5-2.52-56$ & 0.0 & 31.7 & 32.0 & 35 & & 0.1 & 0.7 \\
\hline $6-1.55-63$ & 0.0 & 20.5 & 36.1 & 41 & & 2.1 & 0.0 \\
\hline $6-1.95-101$ & 0.0 & 24.8 & 32.0 & 38 & & 3.0 & 1.5 \\
\hline
\end{tabular}

Joron et al., Srivastava, et al., Fodor et al., in this volume).

The top of the basement (Cores 4 through 6 at 95-130 $\mathrm{cm}$ ), in contact with the sediments, consists of an aphanitic plagioclase-pyroxene basalt grading to coarser grained vesiculated plagioclase-pyroxene basalt (Section 4-6, 130-150 cm). This coarser zone was disrupted by the corer. The next zone consists of an aphyric, finegrained basalt with glassy margins showing spherulitic textural features. This aphyric zone occurs in Section $5-1$ at a depth of $1=100 \mathrm{~cm}$. The plagioclase occurs as skeletal, "belt-buckle" forms, and as laths with feathery or spiky terminations. Between 100 and $125 \mathrm{~cm}$ depth (Section 5-1), this aphyric zone grades into a coarse-grained plagioclase-pyroxene basalt, which occurs in Section 5-1, at about $125 \mathrm{~cm}$, to Sections 5-2 and $3(0 \simeq 32 \mathrm{~cm})$. The upper part of this coarser grained zone is relatively more vesicular than the other recovered rocks. Below about $35 \mathrm{~cm}$ in Core 5 (Section 3 ), and throughout Core 6 and Core 7 (Section 1), alternating zones (less than $1 \mathrm{~m}$ thick) of coarse- and very coarse grained plagioclase-pyroxene basalt occur (Table 9).

The coarser grained samples are never completely crystalline but contain glassy segregations which may be seen in hand specimens as dark blotches (mesostasis). In thin section, these basalts have both ophitic holocrystalline and glassy variolitic or intersertal areas in close proximity. The glassy areas commonly contain needlelike opaques, dendritic clinopyroxene, and euhedral microphenocrysts of plagioclase. The crystalline areas contain large subhedral crystals of plagioclase and twinned clinopyroxene, almost a gabbroic texture.

The finer grained basalts do not show local contrasts in textures. Still, the more crystalline samples commonly display intergranular textures, whereas those that are more quenched are intersertal or variolitic.

The overall paucity of phenocrysts in all of these samples (never exceeding 1-2\%) makes it difficult to define basaltic types on the basis of phenocryst assemblages. All samples are sparsely plagioclase phyric, and broad petrographic divisions could be made according to the additional rare appearance of olivine and/or clinopyroxene as phenocrysts phase. In many cases, only one such phenocryst may be seen in a thin section, and it seems reasonable at this stage to conclude that all the basalts from this hole are.similar and display only textural differences depending on their cooling histories. Although rather limited, the chemical data on basalts 
from this hole also show very little variation, supporting this conclusion (see following section on geochemistry).

The plagioclase phenocrysts in Hole 424 are usually euhedral, subequant, multiply twinned crystals showing very complex zoning and overgrowths, especially near the top of the section. These crystals are up to $2 \mathrm{~mm}$ in size and are approximately $\mathrm{An}_{60-70}$ in composition. Rare, strongly zoned microphenocrysts also occur in some samples, sometimes as glomerocrysts with clinopyroxene.

Clinopyroxene phenocrysts are euhedral, show slight zonation, and are up to $1 \mathrm{~mm}$ in size. A few examples of simply twinned pyroxenes are found in the coarser rocks.

Two samples contain very rare, large $(0.75 \mathrm{~mm})$ irregular olivine phenocrysts which are anhedral and fractured. In one of these specimens [Sample 424-5-2 (Piece $2 \mathrm{~B})$ ], no olivine was identified in the groundmass, and there is some question as to the origin of these phenocrysts.

The matrix of the basalts consists of plagioclase, clinopyroxene, olivine, titanomagnetite, and glass, with a small amount of alteration and secondary minerals. The morphology of these phases varies according to degree of crystallinity. Glassier samples contain skeletal plagioclase in the matrix. Clinopyroxene may be either anhedral or euhedral, and occurs along with plagioclase as microlites or small glomerocrysts; it tends to be pale brown in color. Sheaf-like clinopyroxene also occurs in the glassy basalts. More crystalline and coarser grained samples, however, contain twinned groundmass clinopyroxene with an unusual feathery lath-like appearance that is distinct from the more common platy ophitic form. The small amounts of olivine tend to be euhedral, have higher relief, are not tinted brown or pink, and sometimes have associated clays around the edges. Titanomagnetite is usually skeletohedral, especially in the coarser grained samples.

Sulfides of magmatic origin occur as spheres in finer grained samples and fill spaces between plagioclase and clinopyroxene in coarser grained samples.

\section{Holes 424A, B, and C}

Basalt recovered from these holes is similar, megascopically and microscopically, to the basalt from Hole 424. Unfortunately, the rocks recovered from Holes 424A and C consist mostly of small, uncut fragments that cannot be oriented. Hence, correlation of cooling units from hole to hole is not possible.

Eight small pieces of glassy, slightly plagioclase-phyric basalt were recovered from Hole 424A. In thin section, these rocks resemble those recovered from Hole 424 , and also have filled vesicles and alteration of a groundmass phase. In addition, a fragment of lithified carbonate ooze was retrieved from the middle of the core. This ooze fragment contains two pieces of fresh, very glassy basalt with microlites of plagioclase and clinopyroxene and a row of brown plagioclase spherulites.

At Hole 424B, five cooling units can be distinguished on the basis of grain size and the degree of crystallinity, but mineralogically the units are similar. Thin section studies and modal analyses (Table 9) again indicate that these rocks are petrographically indistinguishable from those at Hole 424. Phenocrysts of plagioclase are subhedral and subequant, and sometimes show zoning. Pyroxene phenocrysts are generally subhedral, although lath-like, twinned forms also occur. Rare olivine phenocrysts are present in some samples.

In the groundmass, the plagioclase is skeletal, often with feathery terminations. The clinopyroxene is dominantly sheaf-like, but small subhedral to anhedral crystals occur. It is possible that extremely small olivine crystals also may occur in the groundmass, but these were definitively identified in only a few samples. The glass ranges in abundance from about 20 to 90 per cent, increasing toward the margins of each cooling unit.

Many of the samples show signs of alteration. Vesicles are often lined with a green clay mineral (smectite?), or filled with a yellowish brown amorphous material. The same green clay mineral also occurs in patches in the groundmass. However, in some samples it appears to form pseudomorphs after a groundmass phase, probably olivine.

The basalts recovered from Hole $424 \mathrm{C}$ differ mineralogically only slightly from those recovered at Holes $424 \mathrm{~A}, \mathrm{~B}$, and C. However, these rocks show more pervasive alteration of the glass and groundmass phases to green clay minerals and brown oxides.

\section{IGNEOUS ROCK CHEMISTRY, SITE 424}

Shipboard XRF whole-rock analyses were obtained for six samples from Hole 424 (Table 10). Shipboard data were not obtained from Holes 424A, B, and C but analyses in other reports of this volume (Fodor et al., Joron et al., Srivastava, et al.) show that the basalts in these holes are virtually identical to those of Hole 424 . They probably represent the same eruptive event. The following discussion, based on Hole 424 samples only, therefore applies to the basalts from all four holes.

Hole 424 basalts are enriched in $\mathrm{Fe}_{2} \mathrm{O}_{3}$ and $\mathrm{SiO}_{2}$, and depleted in $\mathrm{MgO}$ and $\mathrm{K}_{2} \mathrm{O}$, and can be classified as tholeiitic ferrobasalts. Dredge hauls from the area have previously revealed the presence of such ferrobasalts (Schilling et al., 1976). Two of the dredges, Southtow 7D-17 and Cocotow 6D-2, together with Site 424, form a north-south transect across the Galapagos Spreading Center.

Figure 25a shows a plot of the $\mathrm{FeO}^{*} /\left(\mathrm{FeO}^{*}+\mathrm{MgO}\right)$ ratio versus $\mathrm{TiO}_{2}$ content for our data and all the analyses presented in the forementioned paper (Schilling et al., 1976). No definite relationship is observed for the $\mathrm{Fe}$ and $\mathrm{Ti}$ contents and the distance from the Galapagos Islands. Figure 25a indicates that the basalts drilled from the southern flank of the Galapagos Spreading Center form a distinctive group in which a different relationship exists between $\mathrm{FeO}^{*} /\left(\mathrm{FeO}^{*}+\mathrm{MgO}\right)$ and $\mathrm{TiO}_{2}$ content than in the dredged samples. Comparison with the two dredge hauls indicates that, although the $\mathrm{TiO}_{2}$ content remains constant, the Site 424 samples have higher $\mathrm{FeO}^{*} /\left(\mathrm{FeO}^{*}+\mathrm{MgO}\right)$ ratios, suggesting a possible change in magma composition with time. 
TABLE 10

Shipboard XRF Major Oxide Analyses of Basalts, Hole 424

\begin{tabular}{lccccccccc}
\hline $\begin{array}{c}\text { Sample } \\
\text { (Interval in cm) }\end{array}$ & $\mathrm{SiO}_{2}$ & $\mathrm{Al}_{2} \mathrm{O}_{3}$ & $\mathrm{Fe}_{2} \mathrm{O}_{3}$ & $\mathrm{MgO}$ & $\mathrm{CaO}$ & $\mathrm{K}_{2} \mathrm{O}$ & $\mathrm{TiO}_{2}$ & $\begin{array}{c}\text { Loss on } \\
\text { Ignition }\end{array}$ & Total \\
\hline 5-1, 9-14 (Piece 2) & 50.37 & 13.51 & 14.27 & 4.35 & 10.42 & 0.09 & 1.86 & 0.62 & 95.49 \\
5-1, 35-40 (Piece 5) & 48.60 & 13.47 & 14.32 & 4.89 & 10.41 & 0.08 & 1.85 & 1.14 & 94.77 \\
5-1,131-136 (Piece 13) & 50.14 & 13.57 & 14.26 & 4.81 & 10.25 & 0.05 & 1.84 & 1.10 & 96.01 \\
5-2, 56-61 (Piece 2B) & 52.42 & 13.88 & 14.65 & 5.28 & 10.40 & 0.06 & 1.92 & -0.38 & 97.22 \\
5-3, 20-23 (Piece 2) & 50.53 & 13.87 & 14.27 & 4.52 & 10.41 & 0.04 & 1.85 & 0.05 & 95.55 \\
7-1, 0-10 (Piece 1) & 50.08 & 13.75 & 14.44 & 4.51 & 10.77 & 0.15 & 1.85 & 0.43 & 95.99 \\
\hline
\end{tabular}
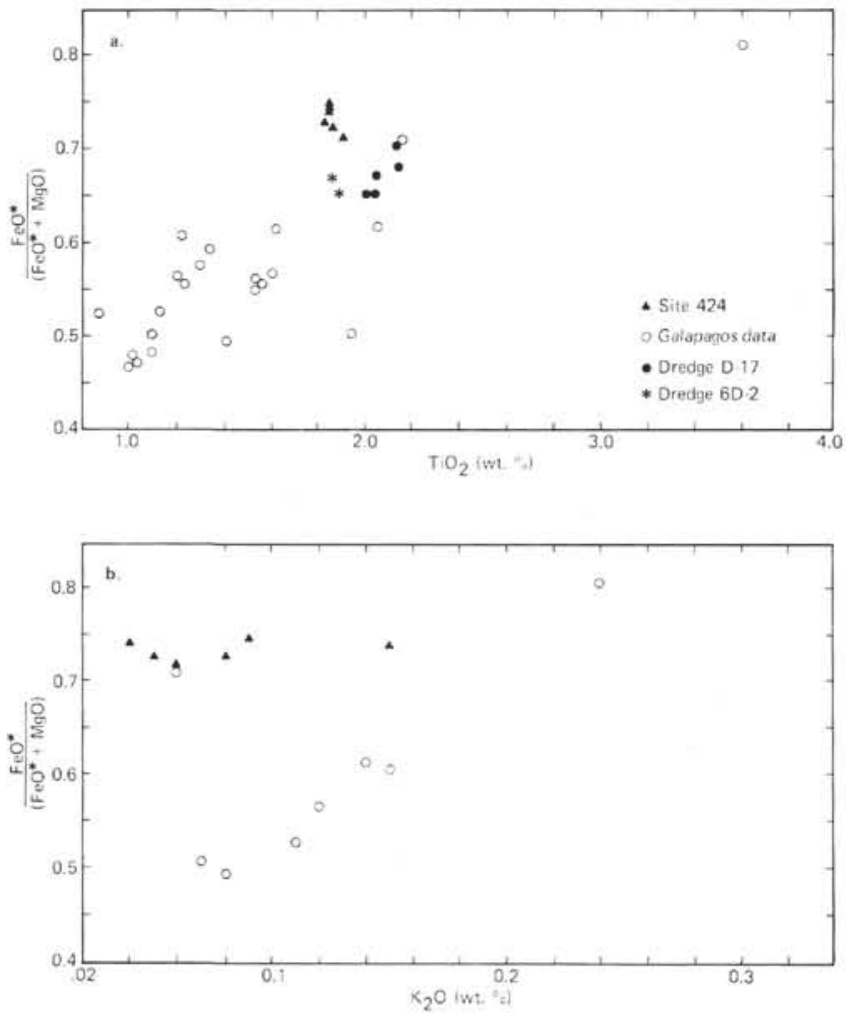

Figure 25. Variation diagrams for basalts of Hole 424 and nearby dredges (a) $\mathrm{FeO}^{*} /(\mathrm{FeO} *+\mathrm{MgO})$ versus $\mathrm{Ti}_{2} \mathrm{O}$ (wt.\%), (b) $\mathrm{FeO} * /(\mathrm{FeO} *+\mathrm{MgO})$ versus $\mathrm{KO}_{2}$ (wt.\%) (Hole 424, Galapagos Rift dredge data (Schilling et al., 1976); dredge D-17 and dredge 6D-2 (Anderson et al., 1975).

This separation is also seen in a graph of the $\mathrm{FeO}^{*} /\left(\mathrm{FeO}^{*}+\mathrm{MgO}\right)$ ratio versus $\mathrm{K}_{2} \mathrm{O}$ content (Figure $25 \mathrm{~b}$ ); however, no data for $\mathrm{K}_{2} \mathrm{O}$ concentrations were reported for the two dredge hauls that make up the north-south transect. The Site 424 basalts appear to have extremely low $\mathrm{K}_{2} \mathrm{O}$ values for such evolved basalts, and again form a distinct group.

Since detailed descriptions are not available for the dredged samples, mineralogical differences are difficult to evaluate. The samples were reported as ranging from "aphyric to plagioclase-phyric, or, more rarely, olivine, porphyritic basalts.' In general, the Site 424 samples are sparsely plagioclase-phyric, with occasional phenocrysts of clinopyroxene, and rarely olivine.

\section{IGNEOUS BASEMENT LITHOLOGY, SITE 425}

Eight meters of basalt was recovered from the 30 meters of basement penetrated at Hole 425. Although very few glassy chilled contacts are found, variations in texture and magnetic properties make it possible to recognize 12 separate cooling units. The thickness of these units (expanded proportionally to fill the drilled interval) varies from 0.5 to 5.9 meters, averaging 2.4 meters. There is no firm evidence that any of the cooling units are either extrusive or intrusive; the possibility remains that the more holocrystalline coarser grained units (e.g., Units 2, 3, 4, and 8) may have been intruded as sills.

The bulk of basalt recovered contains sufficient phenocrysts to allow the distinction of eight lithological units. These will be described in downhole stratigraphic sequence. Representative modal analyses are given in Table 11.

\section{Unit 1: Plagioclase Sparsely Phyric Basalt (5.1 m)}

This unit is composed of three cooling units of, respectively, $0.7,2.8$, and 1.6 meters thickness. The basalt is very fine grained and contains 2 to 3 per cent of plagioclase phenocrysts which are up to $0.5 \mathrm{~mm}$ in size. Core compositions vary from $\mathrm{An}_{75}$ to $\mathrm{An}_{80}$, and these phenocrysts are only slightly zoned. The groundmass consists mainly of clinopyroxene and plagioclase with subordinate titanomagnetite and interstitial glass, forming an intergranular or intersertal texture. Concentrations of glass in areas up to $1 \mathrm{~mm}$ in size cause some samples to appear patchy. The groundmass plagioclase ranges from $A n_{60}$ to $A n_{70}$ in composition and forms laths up to $3 \mathrm{~mm}$ long. Clinopyroxene crystals are smaller, usually granular or anhedral, with grains rarely exceeding $0.1 \mathrm{~mm}$ in diameter. Vesicles are concentrated in the middle of the unit, locally forming up to 15 per cent by volume of the rock.

\section{Unit 2: Plagioclase-Clinopyroxene Sparsely} Phyric Basalt (10.7 m)

Two cooling bodies comprise this unit and are 5.9 and 4.8 meters thick, respectively. The basalt contains 3 to 5 per cent of plagioclase phenocrysts up to $1.2 \mathrm{~mm}$ long. These are similar in composition to those in Unit 1 but are strongly zoned and contain glass inclusions. Scattered phenocrysts of clinopyroxene up to $0.8 \mathrm{~mm}$ in size are less abundant than those of plagioclase and are generally euhedral. The groundmass is composed of pla- 
TABLE 11

Modal Analyses (vol. \%) of Basalts, Hole 425 (1000 counts)

\begin{tabular}{|c|c|c|c|c|c|c|c|c|c|}
\hline 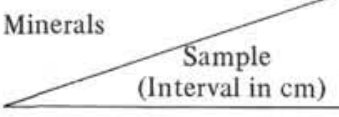 & $\begin{array}{c}7-1 \\
43-57 \\
\end{array}$ & $\begin{array}{c}7-1, \\
129-131 \\
\end{array}$ & $\begin{array}{c}7-2, \\
115-118 \\
\end{array}$ & $\begin{array}{c}8-1, \\
130-134\end{array}$ & $\begin{array}{c}8-1, \\
145-148 \\
\end{array}$ & $\begin{array}{c}9-1, \\
106-110\end{array}$ & $\begin{array}{c}9-2, \\
107-110\end{array}$ & $\begin{array}{c}9-2, \\
145-147 \\
\end{array}$ & $\begin{array}{c}9-3, \\
62-65 \\
\end{array}$ \\
\hline Bulk plagioclase & 44.2 & 41.7 & 42.5 & & 41.6 & 17.7 & & 40.0 & 50.0 \\
\hline Plagioclase phenocryst & & & & 14.5 & & & 1.2 & & \\
\hline Plagioclase matrix & & & & 46.0 & & & 41.6 & & \\
\hline Olivine phenocryst & & & & & 0.3 & & trace & & \\
\hline Olivine matrix & & & & & & 0.9 & & & \\
\hline Clinopyroxene & 38.7 & 37.6 & 46.4 & 36.0 & 46.3 & 3.1 & 40.6 & 49.8 & 49.0 \\
\hline Opaque & 7.4 & 4.6 & & trace & & 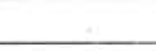 & trace & 7.9 & 1.0 \\
\hline Glass & 8.7 & 14.7 & & 3.5 & & & 16.3 & & \\
\hline Mesostasis & & & 5.5 & & 6.2 & 78.3 & & 2.3 & \\
\hline Phyllosilicate & & & 5.5 & & 5.6 & & & & \\
\hline Vesicle & 1.0 & 1.4 & & & & & 0.3 & & \\
\hline Lithological Unit & 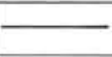 & $1 \longrightarrow$ & 2 & 3 & 4 & $(5)^{\mathrm{a}} \quad 6$ & 7 & $\longrightarrow$ & 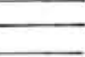 \\
\hline
\end{tabular}

${ }^{\mathrm{a}}$ No data for Unit 5 .

gioclase laths $\left(\mathrm{An}_{55-70}\right)$, granular clinopyroxene, and subordinate titanomagnetite. Rare pseudomorphs of smectite after olivine are found in the groundmass. Patches of glass, sometimes up to $1 \mathrm{~mm}$ across, contain microlites of plagioclase and clinopyroxene in the form of radial clusters or as overgrowths on plagioclase microphenocrysts. Larger crystals from the coarser grained lower cooling unit are commonly strained and microfractured. Vesicles range from 0.3 to $0.5 \mathrm{~mm}$ in diameter and constitute up to 5 per cent of the rock by volume. These are usually filled with carbonate, smectite, or a meniscus of altered glassy material.

\section{Unit 3: Plagioclase Phyric Basalt (3.4 m)}

This unit contains from 15 to 20 per cent phenocrysts of dominantly plagioclase, with minor olivine and clinopyroxene. Plagioclase forms both equant single crystals and glomerocrysts from 1 to $5 \mathrm{~mm}$ in size and is significantly more calcic than that from other units. Core compositions average $\mathrm{An}_{90}$ and the crystals are zoned to approximately $\mathrm{An}_{80}$ near the rims. Phenocrysts of olivine $\left(\mathrm{Fo}_{85}\right)$ are relatively fresh and usually glomerophyric with plagioclase. The groundmass is coarser grained and almost holocrystalline, the average grain size being close to $1 \mathrm{~mm}$. The dominant groundmass phase is again plagioclase $\left(\mathrm{An}_{60-75}\right)$ and clinopyroxene, with minor titanomagnetite forming a typically intergranular texture. Interstitial areas contain graphic intergrowths of plagioclase and clinopyroxene. Vesicles are rare in this unit.

\section{Unit 4: Plagioclase-Clinopyroxene-Olivine Sparsely Phyric Basalt $(0.9 \mathrm{~m})$}

This single cooling unit is similar to Unit 2, except that rare olivine phenocrysts (approximate composition $\mathrm{Fo}_{80}$ ) as large as $1.5 \mathrm{~mm}$ are found in addition to those of plagioclase and clinopyroxene. The groundmass is fine-grained, containing plagioclase laths 0.2 to $0.5 \mathrm{~mm}$ in length, granular pyroxene, and subordinate titanomagnetite. The rock is approximately 80 per cent crystalline with an intersertal texture. The upper contact of this unit is not well defined and may be a lower, less porphyritic, part of Unit 3 forming a single eruptive or intrusive body.

\section{Unit 5: Plagioclase-Pyroxene Sparsely Phyric Basalt (1.2 m)}

The two cooling units comprising Unit 5 are relatively rich in glass and contain sparse microphenocrysts of skeletal plagioclase $\left(\mathrm{An}_{75}\right)$ and clinopyroxene in a pilotaxitic groundmass. The rock is usually slightly vesicular (up to $1 \%$ by volume).

\section{Unit 6: Plagioclase Sparsely Phyric Basalt $(1.5 \mathrm{~m})$}

Microphenocrysts and microglomerocrysts of plagioclase $0.5 \mathrm{~mm}$ in diameter are contained in a pilotaxitic groundmass. Quenched skeletal plagioclase laths up to $0.7 \mathrm{~mm}$ in length form nucleation centers for granular or fibrous clinopyroxene. Near the base of this unit rare anhedral olivine microphenocrysts are found, usually as glomerophyric clots with plagioclase.

\section{Unit 7: Plagioclase-Olivine Sparsely Phyric Basalt (2.8 m)}

This unit contains glomerophyric aggregates of slightly zoned plagioclase $\left(\mathrm{An}_{80} 0.8 \mathrm{~mm}\right.$ in length) and subhedral to rounded olivine $\left(\mathrm{FO}_{75}, 0.4 \mathrm{~mm}\right.$ in diameter). The groundmass is composed of plagioclase microlites (up to $0.04 \mathrm{~mm}$ in length), granules, and incipient crystals of clinopyroxene (up to $0.05 \mathrm{~mm}$ ), skeletal opaque minerals, and cryptocrystalline aggregates of all three phases in a glassy hyalopilitic mesostasis.

\section{Unit 8: Plagioclase Sparsely Phyric Basalt (3.2 m)}

This unit is relatively coarse grained and contains the most completely crystalline basalts found at this site. Euhedral plagioclase phenocrysts up to $0.8 \mathrm{~mm}$ in length and average composition $\mathrm{An}_{85}$ are set in an inter- 
granular groundmass with a grain size close to $0.5 \mathrm{~mm}$. The groundmass is composed of dominantly plagioclase laths $\left(\mathrm{An}_{60-75}\right)$ and clinopyroxene, with minor titanomagnetite.

\section{Alteration in Hole 425 Basalts}

A large number of basalt fragments recovered from this hole tend to be equidimensional with many surfaces showing evidence of weathering. Freshly drilled surfaces are relatively rare, except on the more massive doleritic rocks from the centers of some cooling units. The weathered surfaces are coated with a thin irregular crust of brown amorphous oxides, carbonate, and pale blue or green smectite. Up to $1 \mathrm{~cm}$ of basalt adjacent to these weathered surfaces is yellowish or sometimes darker than the fresh basalt interior, forming a prominent weathering rind visible on cut surfaces.

Vesicles, when present, are nearly always lined or filled with smectites, amorphous oxides, and, occasionally, carbonate or zeolite. Small veins of these minerals, sometimes with pyrite and chalcopyrite, are common, especially in basalts from the deeper parts of the hole. In general, the abundance of these secondary hydrothermal minerals increases with depth.

Completely fresh glass is very rare in the basalts from this hole, and the glassy mesostasis is usually altered to smectites and other clay minerals. Olivine, on the other hand, remains relatively fresh and although many samples contain crystals veined with reddish oxides, complete replacement is rare. Other pyrogenic phases such as plagioclase and clinopyroxene remain in their pristine state.

The ore minerals found at this site are of two origins-pyrogenic and hydrothermal. Titanomagnetite and sulfide spheres occur as primary phases, whereas pyrite and chalcopyrite are found as precipitates in veins and fracture fillings. These secondary sulfides fill voids and directly replace the primary magmatic constituents.

Surprisingly, the degree of hydrothermal alteration is greater at this site than that in the basalts from the Mounds Hydrothermal Field (Site 424).

\section{IGNEOUS ROCK CHEMISTRY, HOLE 425}

X-ray fluorescence analyses for major oxides and trace elements are presented in Table 12 for 10 samples (data from Joron et al., this volume). These samples were chosen from the freshest material and are representative of the eight lithological units from this hole.

All the basalts from this hole are mildly oversaturated in silica and contain between 7.0 and 7.7 per cent $\mathrm{MgO}$. These rocks are characterized by a relatively high content of $\mathrm{CaO}(11.2-12.0 \%)$ and low abundances of both the alkalies $\left(1.8-2.2 \% \quad \mathrm{Na}_{2} \mathrm{O}\right.$ and less than $0.08 \%$ $\mathrm{K}_{2} \mathrm{O}$ ) and the incompatible minor oxides and trace elements (e.g., 1.0-1.4\% $\mathrm{TiO}_{2} ; 50-70 \mathrm{ppm} \mathrm{Zr}$ ). In these respects, they resemble normal Mid-Oceanic Ridge $\mathrm{Ba}$ salts (MORB). However, these basalts are more "fractionated" than normal MORBs, and the relative enrichment in iron $\left(10.7-12.9 \%\right.$ as total $\left.\mathrm{Fe}_{2} \mathrm{O}_{3}\right)$ is an established feature of basalts which have been erupted at "fast"'-spreading ridges (Kay et al., 1970; Clague and Bunch, 1976). They are only moderately fractionated, however, in comparison with many others that have been recovered from fast-spreading ridges in which $\mathrm{Fe}_{2} \mathrm{O}_{3}$ contents as high as 20 per cent have been recorded in basalts dredged from the Galapagos Rift (Schilling et al., 1976). Basalts similar to those from this hole are described from elsewhere along the Galapagos Rift (Site 424, this volume; Anderson et al., 1975; Schillling et al., 1976); from the East Pacific Rise (Sites 420-423, $427-429$, this volume), as well as from the Nazca Plate (DSDP Leg 34, Bunch and LaBorde, 1976; Kempe, 1976) and the Juan de Fuca Ridge (Detrick and Lynn, 1975).

Magnesium variation diagrams (versus $\mathrm{Al}, \mathrm{Fe}$, and $\mathrm{Ca}$, Figure 26) and binary trace element plots (e.g., $\mathrm{Zr}$ versus $\mathrm{Ti}$ and $\mathrm{Ni}$; respectively, Figures 27 and 28) show that the narrow range of chemical compositions of these basalts is systematic. For the aphyric and sparsely phyric samples, $\mathrm{MgO}$ correlates positively with $\mathrm{Al}, \mathrm{Ca}$, $\mathrm{Ni}$, and $\mathrm{Cr}$ and negatively with $\mathrm{Fe}, \mathrm{Mn}, \mathrm{Na}, \mathrm{Ti}$, and $\mathrm{Zr}$. A good straight-line correlation is observed between stable, incompatible elements such as $\mathrm{Ti}$ and $\mathrm{Zr}$ (Figure 27), whereas compatible trace elements such as $\mathrm{Ni}$ (Figure 28) and $\mathrm{Cr}$ become strongly depleted in the more evolved samples. Abundances of $\mathrm{Sr}$ and $\mathrm{Rb}$ are low and remain unchanged.

It is clear from an inspection of Table 12 that several adjacent lithological groups are similar in composition, and, broadly speaking, the aphyric or sparsely phyric analyses fall into three groups.

Units 5, 6, 7, and 8 contain the least evolved rocks from this hole, having an $\mathrm{F} /(\mathrm{F}+\mathrm{M})[\mathrm{FeO} /(\mathrm{FeO}+$ $\mathrm{MgO}$ ), total $\mathrm{Fe}$ as $\mathrm{FeO}]$ ratio of 0.57 and an average titania content of 1 per cent. Units 2 and 4 are slightly more fractionated $\left.[\mathrm{F} / \mathrm{F}+\mathrm{M}) \sim 0.59, \mathrm{TiO}_{2} \sim 1.2 \%\right]$, and the uppermost Unit 1 is composed of basalt with $\mathrm{F} /(\mathrm{F}+\mathrm{M}) \sim 0.62$ and $\mathrm{TiO}_{2} \sim 1.4$ per cent. The degree of fractionation, therefore, increases with stratigraphic height, with the youngest lithological unit showing the greatest enrichment in iron.

Strongly porphyritic rocks are found only in Unit 3 and locally in Unit 8. Analyses of these samples (Analyses 3 and 10, Table 12) show a relative enrichment in $\mathrm{CaO}$ and $\mathrm{Al}_{2} \mathrm{O}_{3}$ and depletion of $\mathrm{Fe}_{2} \mathrm{O}_{3}$ and the incompatible elements, which is in accordance with the high modal abundance of plagioclase (up to $20 \%$ ).

The relationships between the cooling, lithological, magnetic, and chemical units are summarized in Figure 29 , and despite poor recovery of material from this hole the various stratigraphies correlate well.

\section{PALEOMAGNETISM OF IGNEOUS ROCKS, SITE 424}

\section{Magnetic Location and Age}

The variations of the total magnetic field were recorded along a north-south profile across the Galapagos Spreading Center. From the anomaly pattern, Site 
TABLE 12

XRF Major Oxide and Trace Element Analyses, and CIPW Norms of Basalts from Hole 425

\begin{tabular}{|c|c|c|c|c|c|c|c|c|c|c|}
\hline Analysis & 1 & 2 & 3 & 4 & 5 & 6 & 7 & 8 & 9 & 10 \\
\hline Core-Section & $7-1$ & $7-2$ & $7-3$ & $8-1$ & $9-1$ & $9-1$ & $9-1$ & $9-2$ & $9-3$ & $9-3$ \\
\hline Interval $(\mathrm{cm})$ & $44-47$ & $52-54$ & $55-59$ & $90-95$ & $105-110$ & $26-28$ & $59-66$ & $105-110$ & $68-73$ & - \\
\hline Lithological Unit & 1 & 2 & 2 & 3 & 4 & 5 & 6 & 7 & 8 & 8 \\
\hline \multicolumn{11}{|c|}{ Major Elements (wt. \%) } \\
\hline $\mathrm{SiO}_{2}$ & 50.44 & 50.58 & 50.56 & 50.17 & 50.61 & 50.32 & 50.14 & 50.44 & 50.49 & 51.48 \\
\hline $\mathrm{TiO}_{2}^{2}$ & 1.42 & 1.19 & 1.17 & 0.98 & 1.18 & 0.99 & 0.98 & 0.97 & 0.99 & 0.99 \\
\hline $\mathrm{Al}_{2} \mathrm{O}_{3}$ & 13.55 & 14.05 & 13.71 & 15.13 & 13.77 & 13.95 & 13.99 & 13.72 & 13.88 & 14.33 \\
\hline$\Sigma \mathrm{Fe}_{2} \mathrm{O}_{3}{ }^{\mathrm{a}}$ & 12.92 & 11.63 & 11.95 & 10.65 & 11.99 & 11.57 & 11.53 & 11.58 & 11.53 & 10.78 \\
\hline $\mathrm{MnO}^{2}$ & 0.18 & 0.17 & 0.18 & 0.15 & 0.17 & 0.19 & 0.18 & 0.17 & 0.17 & 0.17 \\
\hline $\mathrm{MgO}$ & 7.03 & 7.58 & 7.48 & 7.20 & 7.51 & 7.59 & 7.33 & 7.65 & 7.31 & 7.28 \\
\hline $\mathrm{CaO}$ & 11.28 & 11.94 & 11.88 & 12.77 & 11.69 & 12.30 & 12.32 & 12.05 & 11.94 & 12.47 \\
\hline $\mathrm{Na}_{2} \mathrm{O}$ & 2.18 & 2.08 & 2.09 & 1.88 & 2.05 & 2.08 & 1.96 & 1.98 & 1.83 & 2.04 \\
\hline $\mathrm{K}_{2} \mathrm{O}$ & 0.02 & 0.01 & 0.02 & 0.01 & 0.03 & 0.08 & 0.08 & 0.03 & 0.05 & 0.01 \\
\hline $\mathrm{P}_{2} \mathrm{O}_{5}$ & 0.09 & 0.07 & 0.10 & 0.05 & 0.08 & 0.08 & 0.06 & 0.09 & 0.06 & 0.08 \\
\hline $\mathrm{H}_{2} \mathrm{O}$ & 0.10 & 0.01 & 0.33 & - & 0.24 & 0.43 & 0.75 & 0.62 & 0.33 & - \\
\hline Total & 99.20 & 99.32 & 99.43 & 99.01 & 99.31 & 99.57 & 99.32 & 99.30 & 98.98 & 99.58 \\
\hline \multicolumn{11}{|c|}{ Trace Elements (ppm) } \\
\hline $\mathrm{Zr}$ & 68 & 67 & 65 & nd & 62 & 50 & 51 & 55 & 53 & 47 \\
\hline $\mathrm{Rb}$ & 0.1 & 0.1 & 0.1 & 0.1 & 0.1 & 0.4 & 0.1 & 0.5 & 0.1 & - \\
\hline $\mathrm{Sr}$ & 56 & 57 & 56 & 54 & 53 & 49 & 47 & 48 & - & 50 \\
\hline Co & 107 & 141 & 133 & 90 & 101 & 115 & 90 & 120 & 135 & 99 \\
\hline $\mathrm{Ni}$ & 48 & 64 & 60 & 59 & 64 & 78 & 66 & 65 & 72 & 71 \\
\hline $\mathrm{Cr}$ & 141 & 215 & 227 & 311 & 241 & 263 & 300 & 264 & 244 & 294 \\
\hline V & 375 & 383 & 331 & 286 & 327 & 319 & 317 & 475 & 309 & 318 \\
\hline \multicolumn{11}{|c|}{ C.I.P.W. Norms (mol. \%) ${ }^{\mathrm{b}}$} \\
\hline Qtz & 2.32 & 1.74 & 2.00 & 1.78 & 2.18 & 0.82 & 1.57 & 1.90 & 2.55 & 2.94 \\
\hline Or & 0.12 & 0.05 & 0.12 & 0.06 & 0.18 & 0.47 & 0.47 & 0.18 & 0.29 & 0.06 \\
\hline $\mathrm{Ab}$ & 18.45 & 17.60 & 17.51 & 15.90 & 17.34 & 17.60 & 16.58 & 16.75 & 15.48 & 17.26 \\
\hline An & 27.12 & 29.00 & 28.06 & 32.81 & 28.28 & 28.49 & 29.14 & 28.46 & 29.51 & 29.91 \\
\hline Di & 23.28 & 24.40 & 24.80 & 24.74 & 23.95 & 26.24 & 25.93 & 25.19 & 24.05 & 25.74 \\
\hline $\mathrm{Hy}$ & 21.54 & 21.04 & 21.02 & 18.93 & 21.58 & 20.44 & 19.88 & 21.12 & 21.75 & 18.84 \\
\hline Mgt & 2.23 & 2.00 & 2.13 & 1.84 & 2.07 & 2.00 & 1.99 & 2.00 & 1.99 & 1.85 \\
\hline II & 2.70 & 2.26 & 2.22 & 1.86 & 2.24 & 1.98 & 1.86 & 1.84 & 1.88 & 1.88 \\
\hline Ap & 0.21 & 0.16 & 0.23 & 0.11 & 0.19 & 0.19 & 0.14 & 0.21 & 0.14 & 0.18 \\
\hline $\mathrm{F} /(\mathrm{F}+\mathrm{M})$ & 0.62 & 0.58 & 0.59 & 0.57 & 0.59 & 0.58 & 0.59 & 0.58 & 0.57 & 0.57 \\
\hline $\mathrm{Ti} / \mathrm{Zr}$ & 125 & 106 & 108 & - & 114 & 119 & 115 & 106 & 112 & 126 \\
\hline
\end{tabular}

${ }^{\mathrm{a}}$ Total $\mathrm{Fe}$ expressed as $\mathrm{Fe}_{2} \mathrm{O}_{3}$.

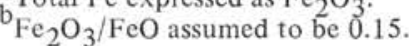

424 was identified as lying within the present Brunhes normal polarity epoch, but very close to the Matuyama boundary. This yields a basement age of slightly less than 0.69 m.y. (see Figure 30).

\section{Rock Magnetic Measurements}

The results of the rock magnetic measurements are listed in Table 13. As the investigated segment of the Galapagos Spreading Center lies very close to the Equator $\left(0^{\circ} 49.40^{\prime} \mathrm{N}\right)$, the rock magnetic inclination must be due to secular variation of the Earth's magnetic field, tilting of the oceanic crust, or orientation errors during sampling. For Holes 424 and $424 \mathrm{~A}$ the inclinations are closely grouped around $0^{\circ}$. The samples from Holes $424 \mathrm{~B}$ and $\mathrm{C}$ show greater differences. If we assume that the nearly identical compositions of basalts in all four holes (e.g., Joron et al., this volume) signify that they were part of the same eruptive event, then these differences were caused by fault-block rotation.

\section{PALEOMAGNETISM OF IGNEOUS ROCKS, HOLE 425}

\section{Magnetic Location and Age}

From the magnetic anomaly pattern, Hole 425 was identified as being within the Matuyama reversed polarity epoch, just beyond the Olduvai normal event. According to the Heirtzler scale, the age of this site therefore should be slightly older than 1.8 m.y. (see Figure $30)$.

\section{Rock Magnetic Measurements}

The results of the rock magnetic measurements are shown in Table 14 and Figure 31. The deviations from zero inclination are considerable for this hole and cannot be explained by orientation errors. There seems to be a gradual and systematic change from about $+30^{\circ}$ inclination for the upper part of the hole to about $-15^{\circ}$ for the lower part. The reason for this phenomenon 


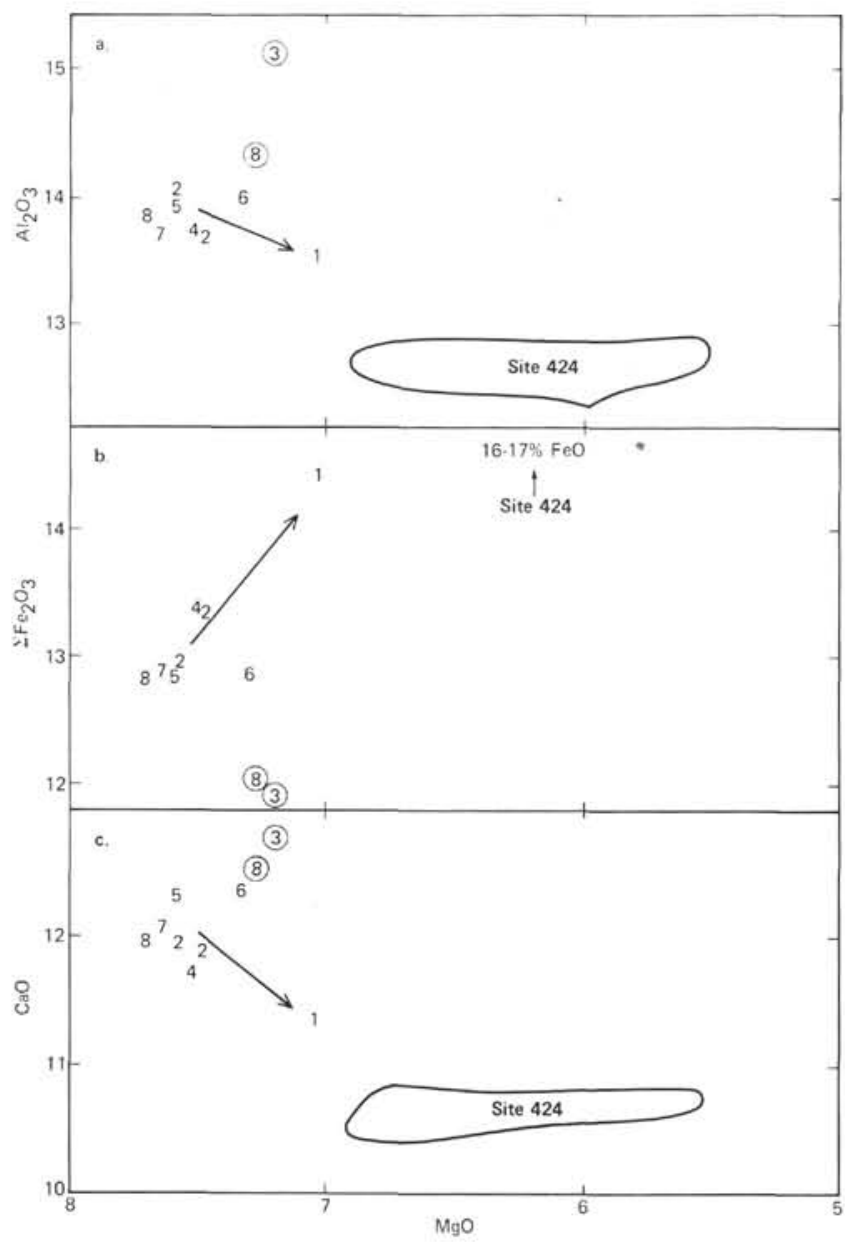

Figure 26. $\mathrm{MgO}$ variation diagram for (a) $\mathrm{Al}_{2} \mathrm{O}_{3}$, (b) $\Sigma \mathrm{Fe}_{2} \mathrm{O}_{3}$, and (c) $\mathrm{CaO}$ for sparsely porphyritic $(<5 \%$ phenocrysts) Hole 425 basalts. Number symbols correspond to lithologic units. Circled units are those with up to 20 per cent phenocrysts.

could be both secular variation of the Earth's magnetic field and/or tilting of the crust. However, the large amount of inclination variation (about $45^{\circ}$ ) seems excessive to have been the result of secular variation. Hence, we suggest that the observed pattern of magnetic inclination can be explained by some variation of the tilting models shown in Figures 32a and b. These diagrams illustrate hypothetical tilting sequences to explain the observation that the upper portion of Hole 425 has positive inclinations and the lower portion negative inclinations. Assuming that only one polarity is present, then a two-stage tilting model is necessary. If, however, opposite polarities are present, only one direction of tilting is necessary to account for the measured inclinations. Some support for the latter is lent by the fact that Hole 425, while ostensibly in the reversed Matuyama epoch, is very close to the boundary of the normal Olduvai event; therefore, it may be reasonable for this particular site to have conflicting polarities.

There is a distinct variation of the intensity of remanent magnetization within Hole 425. This variation is particularly evident for the remanence intensity after

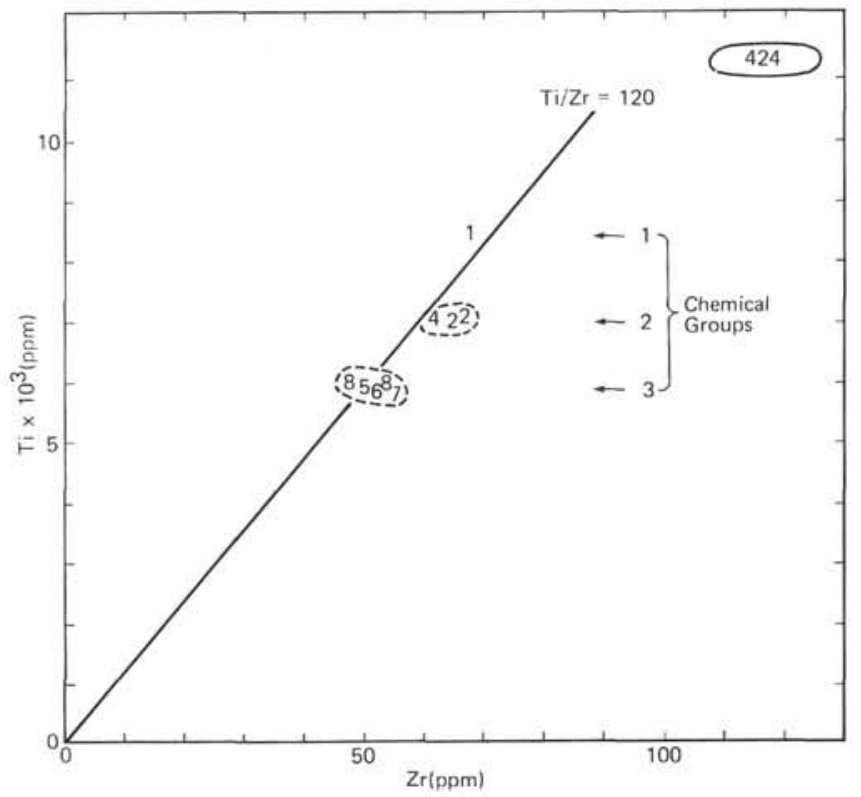

Figure 27. Plot of Ti versus $\mathrm{Zr}$ for Hole 425 basalts. The number symbol corresponds to lithologic units. Basalts from Site 424 plot in the field indicated.

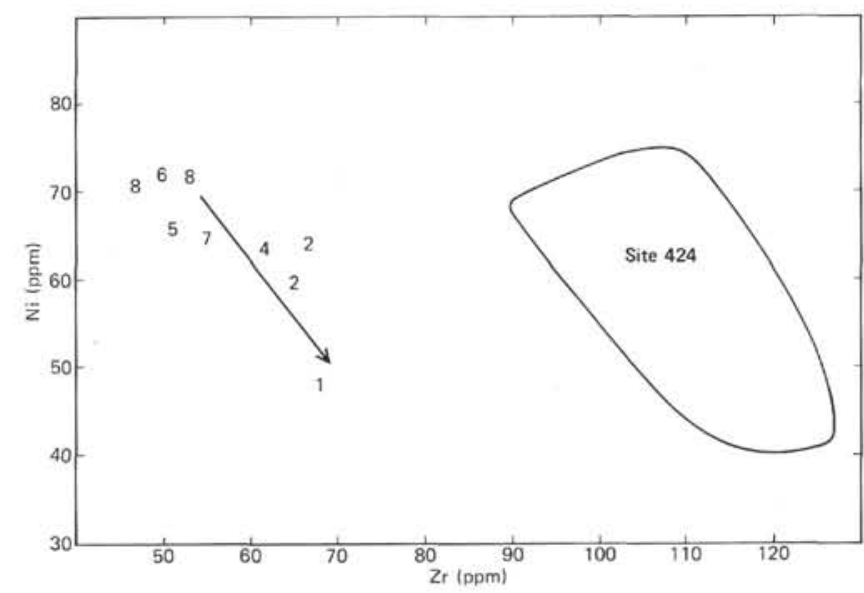

Figure 28. Ni versus $\mathrm{Zr}$ for Hole 425 basalts. Symbols as in Figure 27.

partial alternating field demagnetization in 150 Oe. We interpret the observed remanence variations (see Figure 31 ) to be due to different cooling units with high intensity values at the chilled margins and low values in the central parts. In this fashion, we magnetically define four different cooling units, the boundaries of which coincide with the independently determined lithological units. However, within these magnetically determined units there seem to exist still smaller units. In Figure 31 magnetic and lithological units are juxtaposed.

\section{PHYSICAL PROPERTIES, SITE 424}

\section{Sediments}

At Site 424 the sediments contain foraminifer-nannofossil ooze, green "hydrothermal" mud, and manga- 


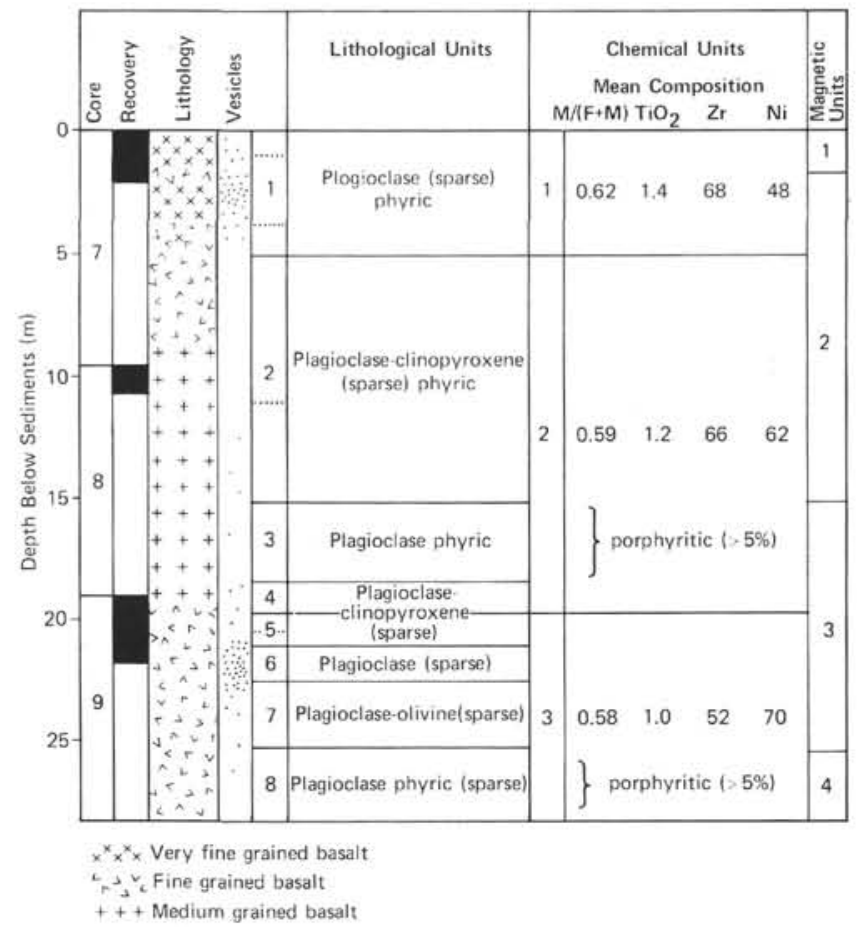

Figure 29. Summary of basement lithology, chemistry, and magnetics, showing correlation between the variously defined units.

nese fragments. The manganese-rich zones were greatly fragmented by drilling, and the ooze layers were visually very similar to those of the PT- 4 area. However, in a very general sense all the sediments at Site 424 showed higher average velocities (Table 15) and wet-bulk densities (Table 16), and lower water contents (Table 16) than the East Pacific Rise sediments. In addition, the depth gradients of these properties were large. For example, at Hole 424 , wet densities at the top of Core 2 are about $1.25 \mathrm{~g} / \mathrm{cm}^{3}$, with water contents of 65 to 75 per cent, only slightly higher and lower, respectively, from values at PT-4. At the bottom of Core 4, just above basement, densities are as high as 1.45 to 1.5 $\mathrm{g} / \mathrm{cm}^{3}$ and water contents are as low as 54 per cent.

Velocities range from near $1.5 \mathrm{~km} / \mathrm{s}$ for the oozes and highly disturbed material to over $1.8 \mathrm{~km} / \mathrm{s}$ in a zone containing manganese fragments and hydrothermal mud mixed with the oozes. It is estimated that in situ velocities of undisturbed hydrothermal mud layers are over $2 \mathrm{~km} / \mathrm{s}$. The general correlation of physical properties with depth and versus lithology is shown on the barrel sheets appended to the end of this chapter. A few vane shear measurements are given in Table 17.

\section{Igneous Rocks}

Igneous rocks from Site 424 are distinguishable from those in the PT- 4 area by having lower mean velocities (Table 18) at high densities (Warren and Rosendahl, this volume). Samples measured from Hole 424, in particular, show a significantly tight cluster with none out of 10 samples ranging in velocity from about 5.5 to $5.8 \mathrm{~km} / \mathrm{s}$, and eight out of 10 samples ranging from about 2.905 to $2.955 \mathrm{~g} / \mathrm{cm}^{3}$. Two minicores were chipped to such an extent that measurements of densities from weight and length could not be made. The mean density of these rocks is slightly greater $\left(0.02 \mathrm{~g} / \mathrm{cm}^{3}\right)$.

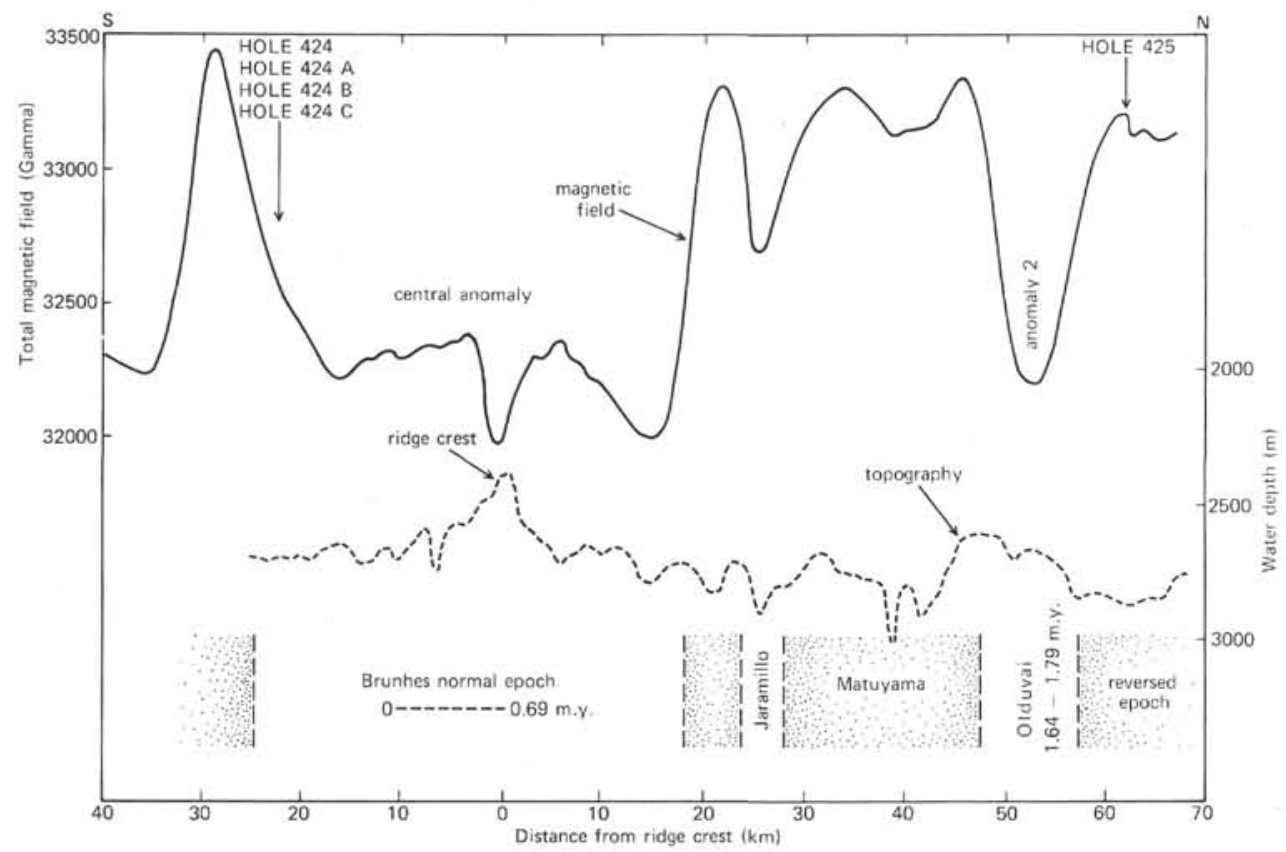

Figure 30. Location of Site 424 and Hole 425 with respect to the Galapagos Rift axis, basement topography, and the total magnetic field measured by the Glomar Challenger between the two sites in May, 1977. 
TABLE 13

Magnetic Properties of Basalts, Site 424

\begin{tabular}{|c|c|c|c|c|c|c|c|c|}
\hline \multirow[b]{2}{*}{$\begin{array}{c}\text { Sample } \\
\text { (Interval in } \mathrm{cm} \text { ) }\end{array}$} & \multicolumn{2}{|c|}{ NRM } & \multirow[b]{2}{*}{$\begin{array}{c}\text { Stable } \\
\text { Inclination } \\
\left({ }^{\circ}\right)\end{array}$} & \multirow[b]{2}{*}{$\begin{array}{l}\mathrm{MDF} \\
(\mathrm{Oe})\end{array}$} & \multirow[b]{2}{*}{$\begin{array}{l}\text { Susceptibility } \\
\left(\mathrm{emu} / \mathrm{cm}^{3}\right. \\
\left.\times 10^{-3}\right)\end{array}$} & \multirow[b]{2}{*}{$\begin{array}{c}Q \\
\text { Factor }\end{array}$} & \multirow[b]{2}{*}{$\begin{array}{l}\text { Rock Type } \\
\text { Basalts }\end{array}$} & \multirow[b]{2}{*}{ Orientation } \\
\hline & $\begin{array}{l}\text { Intensity } \\
\left(\underset{\mathrm{emu} / \mathrm{cm}^{3}}{ }{ }^{-}\right) \\
\times 10^{-3}\end{array}$ & $\begin{array}{l}\text { Inclination } \\
\left.{ }^{\circ}{ }^{\circ}\right)\end{array}$ & & & & & & \\
\hline \multicolumn{9}{|l|}{ Hole 424} \\
\hline 4-6, 113-116 (Piece 3) & 6.623 & -54.2 & +2 & 42 & 3.9 & 5 & $\begin{array}{l}\text { Fine-grained; sparse } \\
\text { vesicles }\end{array}$ & Good \\
\hline $5-1,31-34$ (Piece 5) & 12.969 & -43.9 & +4 & 82 & 2.6 & 14 & $\begin{array}{l}\text { Fine-grained; very } \\
\text { small vesicles }\end{array}$ & Good \\
\hline $5-1,126-129$ (Piece 13) & 5.586 & -42.5 & -10 & 41 & 2.7 & 6 & $\begin{array}{l}\text { Fine-grained; medium } \\
\text { size vesicles }\end{array}$ & Good \\
\hline $5-3,22-25$ (Piece 2 ) & 10.332 & -62.3 & +2 & 45 & 4.0 & 7 & $\begin{array}{l}\text { Fine-grained; tiny, } \\
\text { sparse vesicles }\end{array}$ & Good \\
\hline $5-4,10-13$ (Piece 1$)$ & 6.776 & -63.0 & $-20 ?$ & 40 & 4.7 & 4 & $\begin{array}{l}\text { Fine-grained; rare } \\
\text { pinpoint vesicles }\end{array}$ & Good \\
\hline $6-1,29-32$ (Piece 5) & 3.666 & -36.7 & +14 & 90 & 4.2 & 2 & $\begin{array}{l}\text { Fine-grained; rare, } \\
\text { small vesicles }\end{array}$ & Good \\
\hline $6-1,107-110$ (Piece 10c) & 11.414 & -58.4 & +5 & 40 & 3.4 & 9 & $\begin{array}{l}\text { Fine-grained; large } \\
\text { vesicles }\end{array}$ & Good \\
\hline $6-2,32-35$ (Piece 2a) & 6.541 & -77.8 & $-5 ?$ & 33 & 4.4 & 4 & $\begin{array}{l}\text { Fine-grained; very } \\
\text { small vesicles }\end{array}$ & Good \\
\hline $6-3,21-24$ (Piece 1d) & 6.787 & -58.3 & +5 & 50 & 3.1 & 6 & $\begin{array}{l}\text { Fine-grained; small } \\
\text { number of small } \\
\text { vesicles }\end{array}$ & Good \\
\hline \multicolumn{9}{|l|}{ Hole 424A } \\
\hline $3, \mathrm{CC}, 10-13$ (Piece 1) & 10.369 & - & - & 120 & 1.3 & 22 & $\begin{array}{l}\text { Fine-grained aphyric; } \\
\text { vesicular }\end{array}$ & N.O. \\
\hline \multicolumn{9}{|l|}{ Hole 424B } \\
\hline 5-1, 89-92 (Piece 12) & $\begin{array}{l}10.139 \\
(1.357)\end{array}$ & -48.6 & +9 & 55 & 2.7 & 10 & $\begin{array}{l}\text { Fine-grained; rare } \\
\text { phyric; rare vesicles }\end{array}$ & Fair/good \\
\hline $5-1,139-141$ (Piece 17) & $\begin{array}{l}10.620 \\
(2.015)\end{array}$ & -29.3 & +8.5 & 60 & 2.8 & 10 & $\begin{array}{l}\text { Fine-grained; rare } \\
\text { phyric; small tube } \\
\text { vesicles }\end{array}$ & Fair/good \\
\hline $5-2,15-18$ (Piece 2 ) & $\begin{array}{c}7.240 \\
(0.776)\end{array}$ & -26.9 & +18 & 40 & 3.3 & 6 & $\begin{array}{l}\text { Medium- to fine- } \\
\text { grained; some } \\
\text { vesicles }\end{array}$ & Fair/good \\
\hline $5-2,53-56$ (Piece 6) & $\begin{array}{l}12.379 \\
(1.473)\end{array}$ & $( \pm) 27.7$ & $(\mp) 13$ & 55 & 2.0 & 17 & $\begin{array}{l}\text { Medium- to fine- } \\
\text { grained; some } \\
\text { vesicles }\end{array}$ & Reversed \\
\hline 6-1, 56-59 (Piece 9) & $\begin{array}{l}13.263 \\
(1.664)\end{array}$ & -42.3 & -16 & 70 & 2.1 & 17 & $\begin{array}{l}\text { Fine-grained; some } \\
\text { vesicles }\end{array}$ & Fair/good \\
\hline $6-1,65-68$ (Piece 10) & $\begin{array}{l}9.896 \\
(0.750)\end{array}$ & -60.9 & -11 & 47 & 2.6 & 11 & $\begin{array}{l}\text { Fine-grained; few } \\
\text { vesicles }\end{array}$ & Fair/good \\
\hline Hole 424C & & & & & & & & \\
\hline $3-1,20-23$ (Piece 2) & $\begin{array}{c}7.157 \\
(1.123)\end{array}$ & -39.2 & +23 & 45 & 2.6 & 8 & $\begin{array}{l}\text { Fine-grained with } \\
\text { rare phenocrysts }\end{array}$ & \\
\hline 3-1, 46-49 (Piece 4) & $\begin{array}{l}11.428 \\
(5.958)\end{array}$ & +7.2 & +23 & 155 & 0.78 & 41 & $\begin{array}{l}\text { Very fine grained } \\
\text { with large vesicles }\end{array}$ & \\
\hline
\end{tabular}

\section{PHYSICAL PROPERTIES, HOLE 425}

\section{Sediments}

Because of core disturbance, no velocity or vane shear measurements were made on sediments at this site. Water content, porosities, wet-bulk densities, and grain densities are listed in Table 19. GRAPE porosity and density are plotted versus depth on Figure 33 .

\section{Igneous Rocks}

A sequence of 12 samples were minicored, lapped, and used for density and velocity measurements (Table 20; Figure 34). Velocities are accurate to $\leq \pm 1$ per cent, and densities are accurate to $\leq \pm 0.2$ per cent. The velocities and wet-bulk densities are similar to those of many East Pacific Rise basalts cored on Leg 54 (Warren 
TABLE 14

Magnetic Properties of Basalts, Hole 425

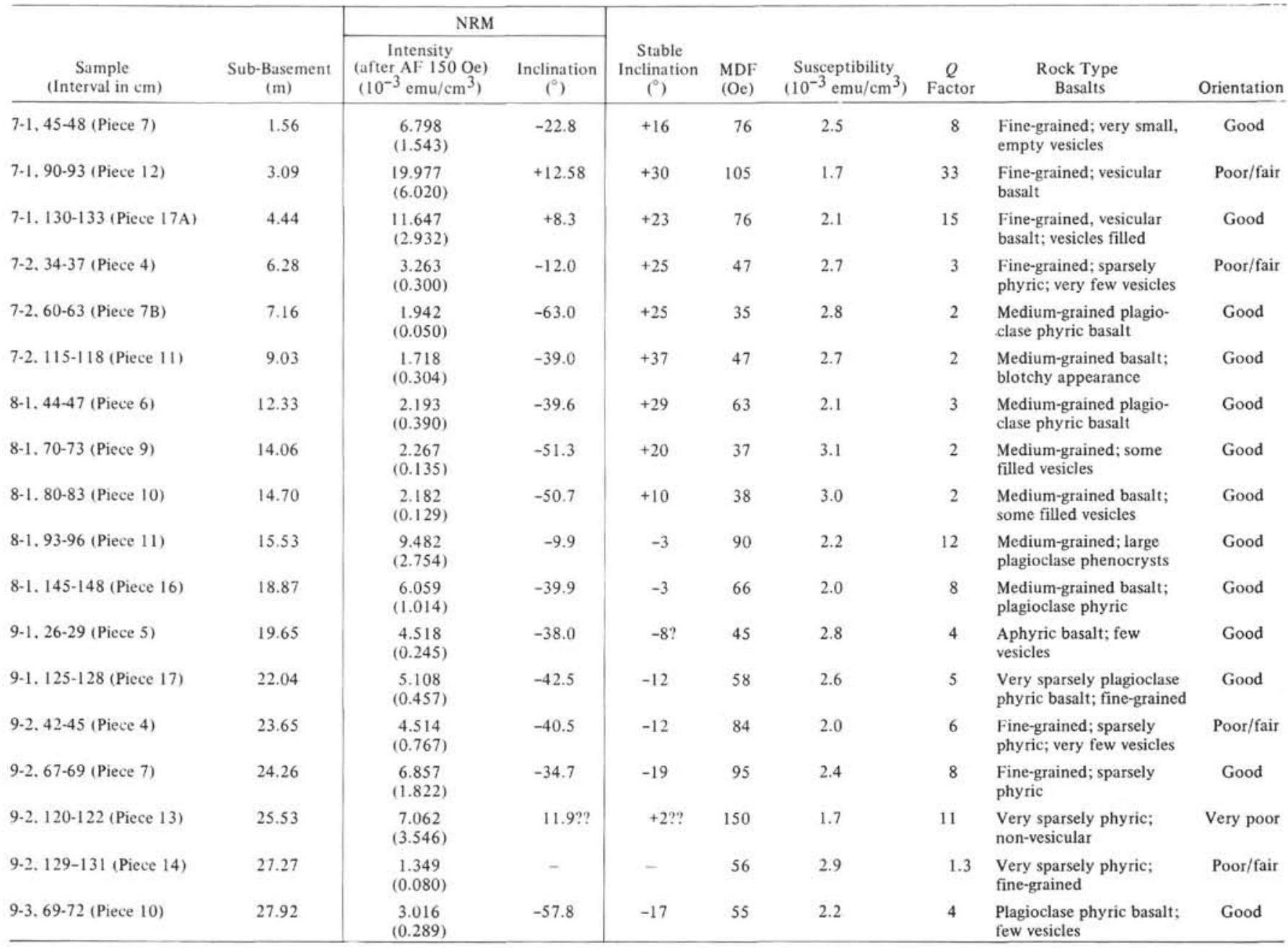

and Rosendahl, this volume). Velocities, at the same densities, are higher than those from Hole 424.

Stratigraphically, velocity-density data correlate well (with the exception of one sample). A minimum of four flow units are suggested by the data.

Grain densities and porosities have been determined for four samples by drying the minicores for five days at $110^{\circ} \mathrm{C}$ (Table 20). These reported values have been corrected for salt content, assuming a salinity of 3.5 per cent.

\section{SUMMARY AND CONCLUSIONS}

Shortly after leaving Site 423 , we were given a DSDP directive, via radio patch and confirmed by cable, to begin steaming immediately toward the Galapagos Spreading Center. The object of this directive was to conduct "drilling trials along the Galapagos Spreading Center" for the sake of the "overall Deep Sea Drilling Project and IPOD-JOIDES plans." The directive initially called for us to locate and drill a supposed geothermal area, south of the Galapagos, in which several groups of mounds and cones were known to exist. These features were thought to have been formed by localized hydrothermal activity along basement faults or fissures.
Upon our arrival in the region about six days later, we were able to establish a north-south drilling transect, across the northwest group of mound and cone chains in the SIO's 1976 deep-tow study of the area (Lonsdale, 1977). The drilling transect (Holes 424C, 424B, 424, and $424 \mathrm{~A}$ ) across this group of mound and cone chains is shown in Figure 4, along with the individual satellite fixes for each station (open circles). Two of our reflection profiles and tracing of a deep-tow profile through the area are shown in Figure 6. The profile locations are given in Figure 4 (the dotted tracks labeled "aa," "bb," and " $\mathrm{cc}$ " correspond to the central parts of Profiles "AA," "BB," and “CC").

\section{Reflection Profiles and Acoustics}

As shown in Figure 6, the Challenger profiles (particularly "AA") reproduce the deep-tow profile tracing to a surprising degree, with virtually every major structure correlative from one to the other. Even some of the mound and cone chains are apparent in our seismic profiles, as are some of the smaller basement faults identified on the deep-tow tracing. Considering the intrinsic shortcomings of these sea-level seismic profiles compared with the deep-tow profile-such as point reflector 


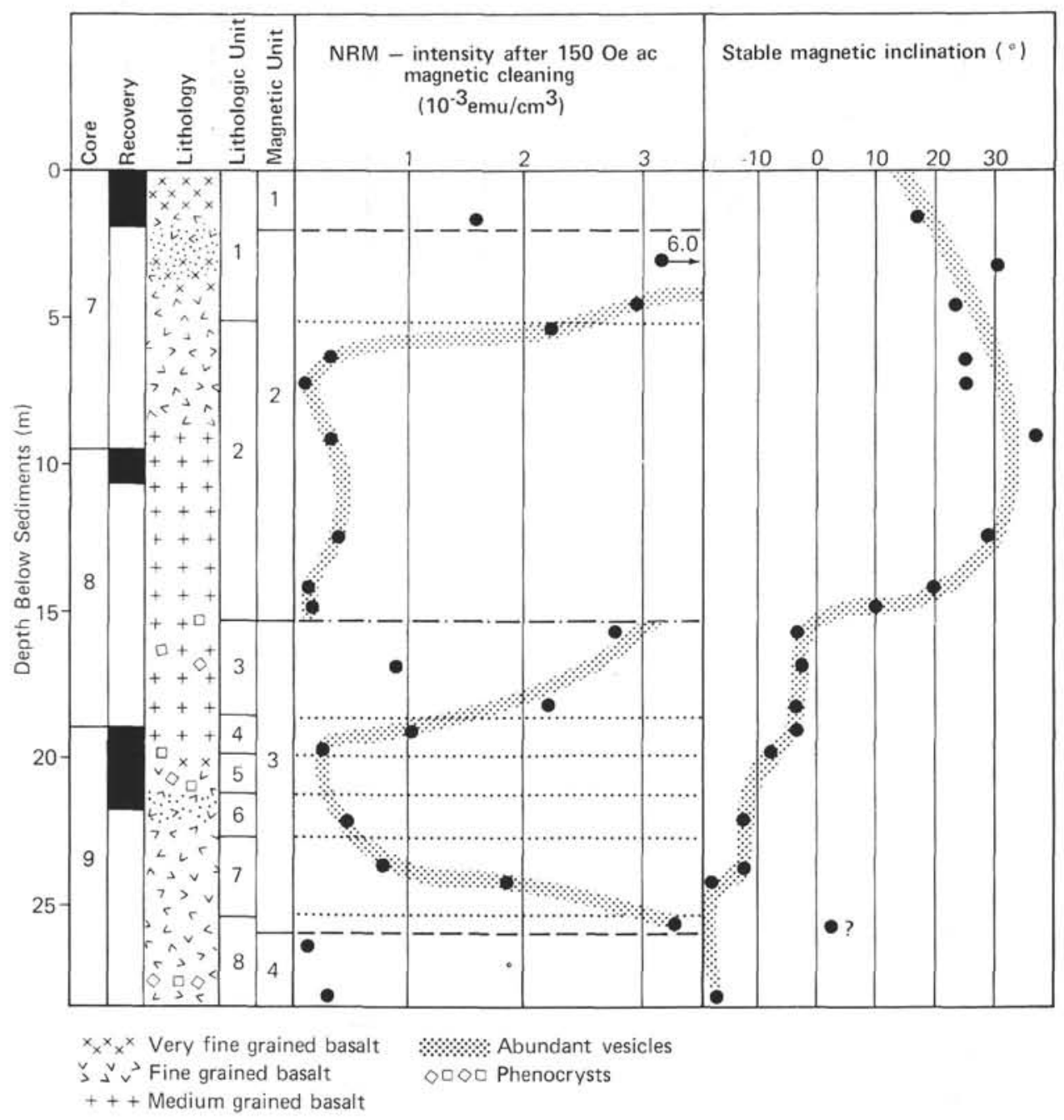

Figure 31. Natural remanent magnetization (NRM) and stable magnetic inclination of basalt minicores, Hole 425, plotted versus depth. Depth assignments assume recovery is proportional to material actually in intervals cored.

and hyperbolic reflection phenomenon, lack of directionality, poorer resolution, longer bubble-pulse trainsthe similarity between them is remarkable. We conclude that sea-level-reflection-profiling systems, as outlined in Site 424 Operations, can be used effectively to relocate even very small drilling targets originally identified by deep-tow surveying.

In spite of the similarities outlined above, the sealevel reflection profiles do not faithfully reproduce the acoustic stratigraphy shown in the deep-tow tracing in Figure 6 and discussed by Lonsdale (1977). The latter profiles show a uniformly thick $(\sim 30-\mathrm{m})$ sediment blanket that contains two regionally continuous internal reflectors. This blanket is disrupted laterally by abrupt changes in reflectivity only over the chains of mounds or cones. The sea-level profiles, on the other hand, show a sediment blanket that is less uniformly thick and disrupted by lateral changes in reflectivity not merely in the vicinity of mapped mounds chains, but elsewhere as well. Moreover, the two internal reflectors reported by Lonsdale (1977) fall within the interval occupied by the sea floor return and cannot be distinguished with any degree of regularity. Of these dissimilarities, the one involving lateral reflectivity changes is most troublesome because it cannot be attributed to one of the shortcomings of sea-level profiling listed in the previous paragraph, nor to the different source frequencies utilized by the two methods (i.e., $4.0 \mathrm{kHz}$ compared with about 200 $\mathrm{Hz}$ ). A possible explanation lies in the fact that the sealevel profiles record variable acoustic responses for a fairly broad swath of sea floor, whereas the deep-tow profiles measure the acoustic sea-floor response along a very narrow path. Given a good reflector which is dispersed in large patches (e.g., manganese cobbles), it is not difficult to imagine how this difference might arise. Alternative explanations involving instrumental artifacts of one or the other systems seem less plausible. We will return to the matter of the internal reflectors in the following section.

\section{Sediment Lithology, Biostratigraphy, and Acoustic Correlation}

As described by Lonsdale (1977), the mounds are small bathymetric features (5-20 m high, 20-50 m wide) 

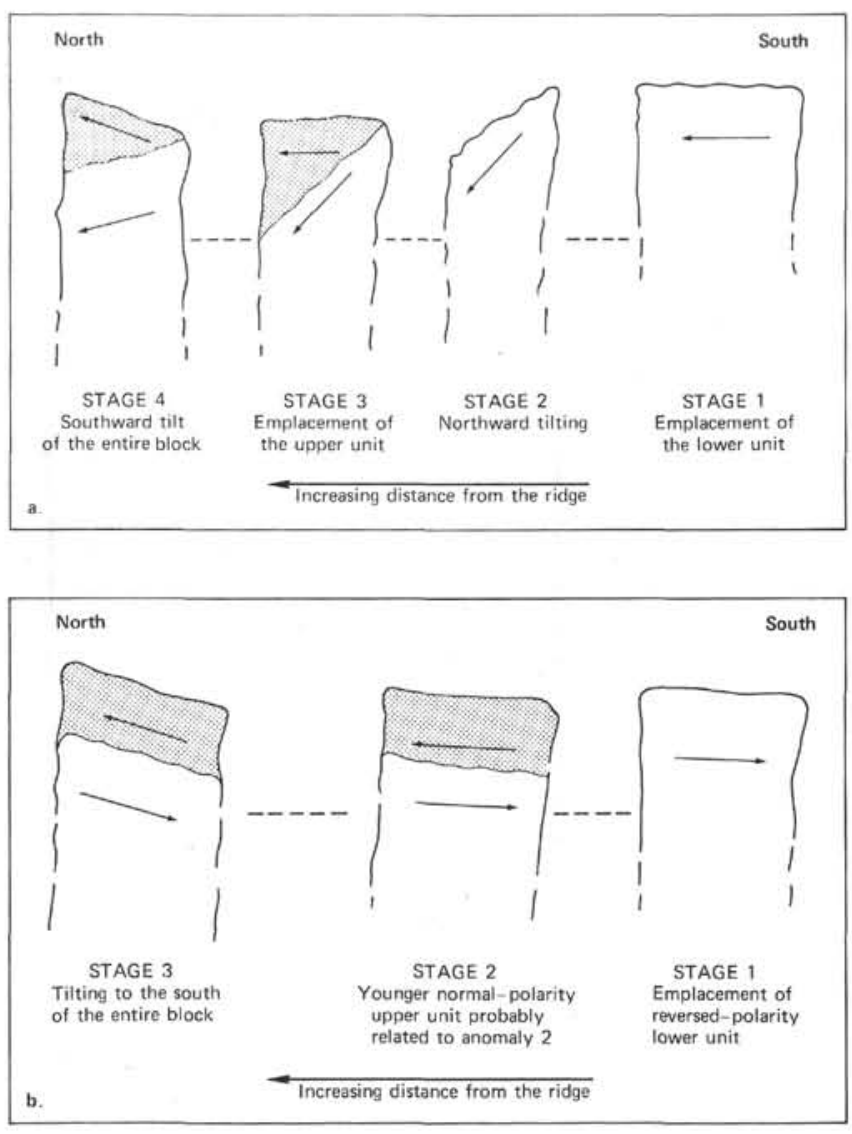

Figure 32. Models showing development of basement magnetic stratigraphy by tilting, Hole 425. (a) assumes one polarity and $O^{\circ}$ inclination when basalts were extruded; and (b) assumes two polarities and $O^{\circ}$ inclination when basalts were extruded.

forming semicontinuous and parallel chains (Figures 2, 3 , and 7 ). In addition to simply protruding above the sea floor, the mounds are highly reflective and disrupt the acoustic continuity of the regional sediment blanket; they usually lie above small basement offsets. Holes $424 \mathrm{~A}$ and 424 are located, as nearly as we can determine, on or very close to mound-like structures, whereas Hole $424 \mathrm{C}$ is located close to but not on a mound. Hole 424B was purposely placed between two mound chains (Figure 9) and was meant to provide a type-area stratigraphic section. It is located at least 180 meters from the nearest mound structure observed with the deep tow.

The basal sediment type at all four holes at Site 424 consists of foraminifer-nannofossil ooze (Figure 9). It shows no evidence of hydrothermal activity, either in the form of observable hydrothermal precipitates, recrystallized (indurated) sediments, or variations in porefluid chemistry. The radiolarian age of the basal unit falls within the Pseudocubus warreni radiolarian Zone $(<0.65 \mathrm{Ma})$, and the occurrence of well-preserved radiolarians at the top of Core 2 in Hole $424 \mathrm{~A}$ indicates that hydrothermal deposition began after $0.4 \mathrm{Ma}$ (Goll, this volume). The basal unit varies in thickness from 14 to 21 meters at Holes 424A, 424, and 424B. Holes 424A,
TABLE 15

Sonic Velocities of Sediments, Site 424

\begin{tabular}{lcrcc}
\hline Core & Section & $\begin{array}{c}\text { Interval } \\
(\mathrm{cm})\end{array}$ & $\begin{array}{c}\text { Velocity } \\
(\mathrm{Km} / \mathrm{s})\end{array}$ & $\begin{array}{c}\text { Temperature } \\
\left({ }^{\circ} \mathrm{C}\right)\end{array}$ \\
\hline $\begin{array}{l}\text { Hole 424 } \\
2\end{array}$ & 3 & 58 & 1.601 & 21 \\
& 4 & 10 & 1.555 & 21 \\
& & 20 & 1.474 & 21 \\
& & 142 & 1.542 & 21 \\
& 6 & 13 & 1.530 & 22 \\
& & & 1.509 & 22 \\
\hline 3 & 1 & 16 & 1.850 & 20 \\
& 2 & 109 & 1.569 & 20 \\
& & 46 & 1.493 & 22 \\
\hline Hole 424A & & & & \\
1 & 2 & 6 & 1.466 & 17 \\
& & 25 & 1.588 & 17 \\
& & 45 & 1.522 & 17 \\
\hline 2 & 1 & 30 & 1.483 & 23 \\
& 2 & 64 & 1.551 & 23 \\
& & 128 & 1.471 & 23 \\
\hline 3 & 2 & 122 & 1.585 & 23 \\
& 3 & 45 & 1.651 & 23 \\
\hline Hole 424B & & & & \\
1 & 2 & 6 & 1.492 & 23 \\
& & 94 & 1.534 & 23 \\
\hline 3 & 1 & - & 1.499 & 23 \\
& 3 & 11 & 1.504 & 23 \\
\hline & & 27 & 1.521 & 23 \\
\hline
\end{tabular}

TABLE 16

Water Content, Porosity, Wet-Bulk Density, and Grain Density of Sediments, Site 424

\begin{tabular}{ccccccc}
\hline Core & Section & $\begin{array}{c}\text { Interval } \\
(\mathrm{cm})\end{array}$ & $\begin{array}{c}\text { Water } \\
\text { Content }(\%)\end{array}$ & $\begin{array}{c}\text { Porosity } \\
(\%)\end{array}$ & $\begin{array}{c}\text { Wet-Bulk } \\
\text { Density } \\
\left(\mathrm{g} / \mathrm{cm}^{3}\right)\end{array}$ & $\begin{array}{c}\text { Grain } \\
\text { Density } \\
\left(\mathrm{g} / \mathrm{cm}^{3}\right)\end{array}$ \\
\hline Hole 424 & & & & & & \\
2 & 6 & 103 & 64.0 & 80.0 & 1.25 & 2.20 \\
2 & 6 & 104 & 71.2 & 90.7 & 1.27 & $4.03^{\mathrm{a}}$ \\
2 & 6 & 105 & 65.2 & 84.6 & 1.30 & 3.91 \\
3 & 1 & 62 & 69.5 & 87.7 & 1.26 & 3.12 \\
3 & 1 & 62 & 66.2 & 83.2 & 1.26 & 2.48 \\
3 & 2 & - & 66.3 & 83.3 & 1.26 & 2.49 \\
3 & 6 & 144 & 62.8 & 92.8 & 1.48 & $(8.37)^{\mathrm{a}}$ \\
4 & 4 & 140 & 58.3 & 87.7 & 1.51 & $(5.26)^{\mathrm{a}}$ \\
4 & 5 & 99 & 56.0 & 80.9 & 1.55 & 3.33 \\
4 & 5 & 102 & 54.0 & 78.9 & 1.46 & 3.18 \\
& & & & & & $<>=2.818$
\end{tabular}

\begin{tabular}{crrrrrr} 
Hole 424A & \multicolumn{1}{c}{} & & & \\
2 & 2 & 43 & & & & \\
2 & 2 & 121 & 46.4 & 64.0 & 1.40 & 2.03 \\
2 & 2 & 124 & 50.1 & 79.7 & 1.37 & 3.94 \\
3 & 3 & 39 & 40.0 & 66.9 & 1.67 & 3.02 \\
3 & 3 & 39 & 37.2 & 62.6 & 1.68 & 2.82 \\
3 & 3 & 50 & 32.7 & 55.5 & 1.70 & 2.56 \\
& & & & & & $\langle>2.87$
\end{tabular}

\begin{tabular}{crrrrrr}
$\begin{array}{c}\text { Hole 424B } \\
1\end{array}$ & 2 & 8 & & & & \\
1 & 2 & 8 & 68.5 & 89.0 & 1.30 & 3.76 \\
1 & 2 & 13 & 69.5 & 87.7 & 1.26 & 3.26 \\
3 & 1 & 108 & 66.4 & 87.3 & 1.31 & 3.49 \\
3 & 1 & 108 & 67.0 & 89.4 & 1.33 & $4.23^{\mathrm{a}}$ \\
4 & 2 & 84 & 45.7 & 71.5 & 1.57 & 2.97 \\
4 & 2 & 84 & 45.2 & 69.4 & 1.54 & 2.73 \\
& & & & & & \multicolumn{2}{c}{$\langle>=3.218$} \\
\hline
\end{tabular}

\footnotetext{
${ }^{\mathrm{a}}$ Excluded from calculation of mean grain density.
} 
TABLE 17

Shear Strength of Sediments, Hole 424

\begin{tabular}{ccccc}
\hline Core Section & $\begin{array}{c}\text { Interval } \\
(\mathrm{cm})\end{array}$ & $\begin{array}{c}\text { Shear Strength } \\
(\mathrm{TSF})\end{array}$ & $\begin{array}{c}\text { Temperature } \\
\left({ }^{\circ} \mathrm{C}\right)\end{array}$ \\
\hline \multirow{2}{*}{2} & 6 & 90 & 0.030 & 19 \\
& & 140 & 0.044 & 19 \\
\hline \multirow{2}{*}{3} & 3 & 143 & 0.038 & 19 \\
& 4 & 30 & 0.052 & 19 \\
& & 70 & 0.059 & 19 \\
& & 106 & Too disturbed & \\
\hline
\end{tabular}

$\mathrm{B}$, and $\mathrm{C}$ also are capped by foraminifer-nannofossil ooze, although the thickness of the unit at Hole $424 \mathrm{~A}$ is only about $30 \mathrm{~cm}$.

Hydrothermal deposits at Site 424 are of two types: (1) an intermixture of $\mathrm{Fe}-\mathrm{Mn}$ material and green hydrothermal mud that takes the form of a black slurry in split cores, and (2) a relatively "clean" green hydrothermal mud low in $\mathrm{Fe}-\mathrm{Mn}$ material. Type 1 deposits characterize the top 10 to 15 meters of sediment found at the mound holes (i.e., Holes 424A and 424), and Type 2 occurs in the interval between the foraminifernannofossil ooze units in Hole 424B and to a very minor degree in Hole 424A. We do not know if Type 2 deposits also occur in Hole 424C. Chemical analyses show that the green hydrothermal mud is enriched in $\mathrm{Si}$ and $\mathrm{Fe}$ and depleted in $\mathrm{Mn}$ and $\mathrm{Al}$.

Radiolarian ages of the uppermost sediments (deposits) at Sites 424 fall within the Collosphaera tuberosa
Zone at Holes 424, 424B, and 424C ( $<200,000$ y.), but within the upper $N$. renilla Zone at Hole $424 \mathrm{~A}$. Apparently, the youngest datable sediments at Hole 424A are 200,000 to 400,000 years old.

Another point that deserves discussion here concerns the nature of the two internal reflectors observed on deep-tow profiles and their relationship to the regional sediment blanket. According to Lonsdale (1977), these reflectors occur at 7 and 15 meters below the sea floor and represent terrigenous volcanic ash layers of regional extent. Their estimated ages are 140,000 and 300,000 years, respectively. These reflectors arch upward at the edges of the mound chains (Figure 3e) and disappear entirely beneath some mounds that protrude above the sea floor (e.g., Lonsdale, 1977). Re-examining the deep-tow profiles, it appears that the average sub-bottom depth to the top reflector lies somewhere between 3 and 6 meters, and the bottom reflector between 9 and 11 meters on Figure 3D and between 12 and 15 meters on Figures 3B and $3 \mathrm{C}$ (computations based upon a $V_{p}$ of $1.54 \mathrm{~km} / \mathrm{s}$ and the two-way reflection time equivalents of the depth intervals given in Figure 3). Hence, the recalculated average ages of these reflectors are 60,000 to 120,000 years and 220,000 to 300,000 years, respectively.

Comparison of the Site 424 lithology and biostratigraphy with the deep-tow reflection profiles casts serious doubts on the correlation of the reflectors to ash layers. Only a single ash layer was found (at Hole 424B) and this zone was much too thin and diluted with foraminifer-nannofossil ooze to produce a detectable

TABLE 18

Igneous Rock Physical Properties, Site 424

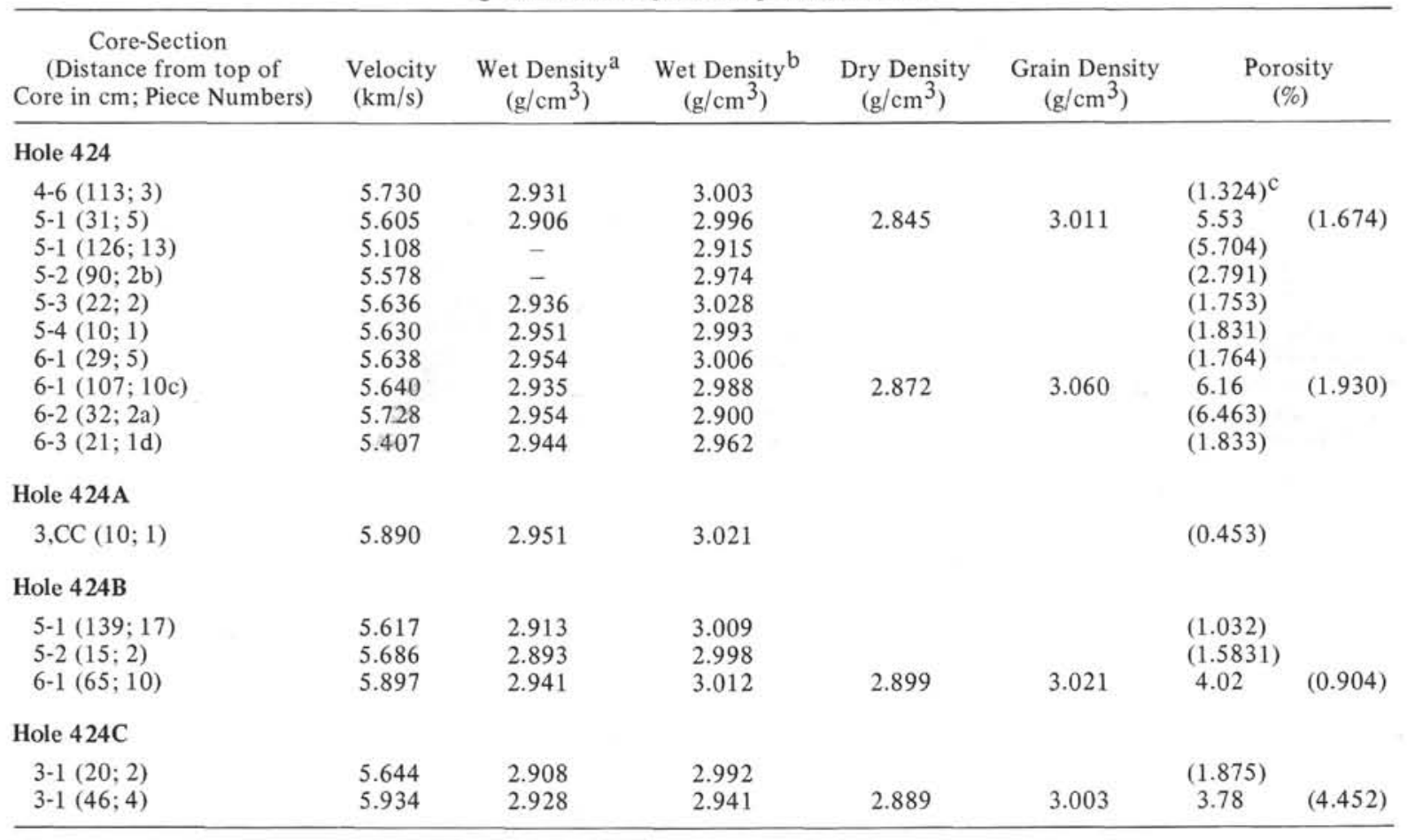

${ }^{\mathrm{a}}$ From wet and length measurements.

From 2-minute GRAPE count, assuming $\rho_{g}=\rho_{g c}=3.03 \mathrm{~g} / \mathrm{cm}^{3}$.

${ }^{\mathrm{c}}$ GRAPE porosities in brackets. 
TABLE 19

Water Content, Porosity, Wet-Bulk Density, and Grain Density of Sediments, Hole 425

\begin{tabular}{|c|c|c|c|c|c|c|}
\hline Core & Section & $\begin{array}{c}\text { Interval } \\
(\mathrm{cm})\end{array}$ & $\begin{array}{c}\text { Water } \\
\text { Content }(\%)\end{array}$ & $\begin{array}{c}\text { Porosity } \\
(\%)\end{array}$ & $\begin{array}{c}\text { Wet-bulk } \\
\text { Density } \\
\left(\mathrm{g} / \mathrm{cm}^{3}\right)\end{array}$ & $\begin{array}{c}\text { Calculated } \\
\text { Grain } \\
\text { Density } \\
\left(\mathrm{g} / \mathrm{cm}^{3}\right)\end{array}$ \\
\hline \multicolumn{7}{|c|}{ Hole 425} \\
\hline 3 & 2 & $144-150$ & 60.3 & 68.6 & 1.14 & 1.393 \\
\hline 3 & 4 & 80 & 62.7 & 90.9 & 1.45 & $(6.278)$ \\
\hline 3 & 5 & $140-150$ & 50.6 & 63.9 & 1.26 & 1.697 \\
\hline
\end{tabular}

acoustic layer. A more plausible correlation is that the internal reflectors are produced by the impedance contrasts between the foraminifer-nannofossil ooze and the Type 2 green hydrothermal muds. This correlation results in radiolarian ages that agree well with the predicted reflector ages and is clearly supported by the physical property measurements, which show large impedance contrasts at the ooze/mud contacts. Moreover, the apparent discrepancy between the recomputed subbottom depth to the lower reflector $(9-15 \mathrm{~m})$ and the measured depth to the mud/ooze contact at Hole 424B (about $23 \mathrm{~m}$ ) is probably a result of incorrect conversion of the time section to depth estimates. In fact, the in situ velocity of the hydrothermal muds is estimated from laboratory measurements to be at least $2.0 \mathrm{~km} / \mathrm{s}$ (see barrel sheets). This value produces a thickness of up to 16 meters for the material between the two reflectors, which is only a few meters less than the measured thickness of the green muds in Hole 424B within the accuracy of the drill hole data.
A final point that must be considered before discussing the origin and spatial relationships of the hydrothermal deposits at Site 424 involves the basaltic basement rocks we recovered. In short, none of the recovered basalts shows any evidence of hydrothermal alteration, in spite of the fact that Holes 424A and 424 are located on or very near mound chains that were thought to have originated over basement faults and fissures by localized hydrothermal venting (Lonsdale, 1977).

\section{Hypotheses on the Origin of the Galapagos Mounds Hydrothermal Deposits}

Dymond et al. (this volume) have summarized three alternative hypotheses for the origin of the iron silicates and $\mathrm{Fe}-\mathrm{Mn}$ oxides at Site 424 :

1) The mounds represent hydrothermal precipitates concentrated above basement vents from which heated fluids are venting or have vented, and which essentially displace original foraminifer-nannofossil sediments;

2) the mounds are hydrothermal precipitates which have replaced foraminifer-nannofossil oozes by dissolution and precipitation; and

3 ) the mounds are the surface expression of a laterally continuous deposit mainly of green muds, whose distribution is delimited by the two reflectors observed with the deep-tow.

In (1) and (2), $\mathrm{Fe}-\mathrm{Mn}$ oxides have fractionated from Fe silicates by passage of hydrothermal fluids through an oxidizing gradient. In (3) this fractionation mechanism may operate, but it could also be that the stratigraphy of the sites implies a time sequence, with Fe sil-
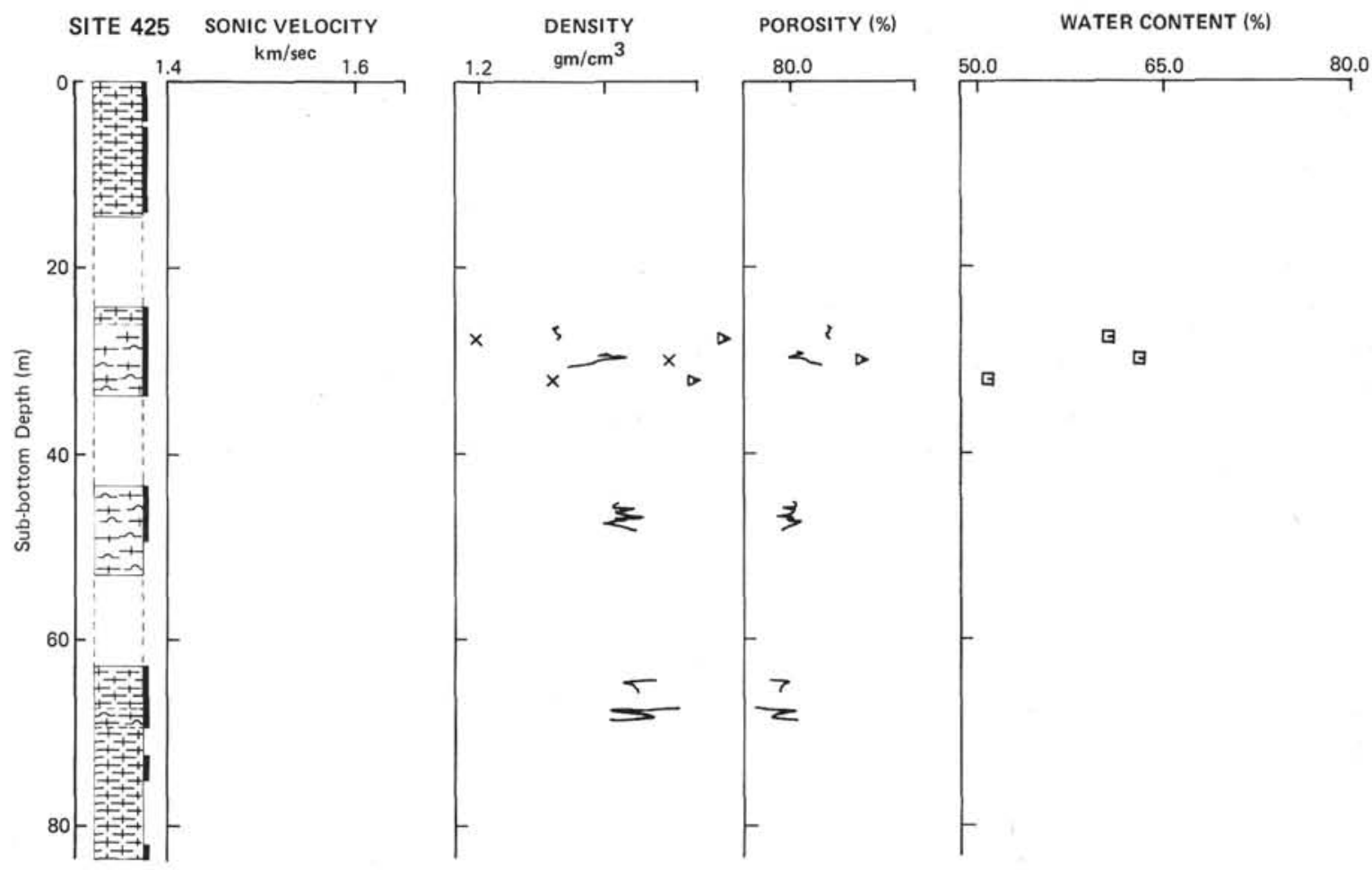

Figure 33. GRAPE density and porosity in sediments plotted versus depth and lithology, Hole 425 . 
TABLE 20

Igneous Rock Physical Properties, Hole 425

\begin{tabular}{llcccc}
\hline $\begin{array}{c}\text { Core-Section } \\
\text { (Distance from Top } \\
\text { of Core in cm: } \\
\text { Piece Number) }\end{array}$ & $\begin{array}{c}\text { Velocity } \\
(\mathrm{km} / \mathrm{s})\end{array}$ & $\begin{array}{c}\text { Wet } \\
\text { Density } \\
\left(\mathrm{g} / \mathrm{cm}^{3}\right)\end{array}$ & $\begin{array}{c}\text { Dry } \\
\text { Density } \\
\left(\mathrm{g} / \mathrm{cm}^{3}\right)\end{array}$ & $\begin{array}{c}\text { Grain } \\
\text { Density } \\
\left(\mathrm{g} / \mathrm{cm}^{3}\right)\end{array}$ & $\begin{array}{c}\text { Porosity } \\
(\%)\end{array}$ \\
\hline $7-1(45 ; 7)$ & 5.630 & 2.907 & & & \\
$7-1(130 ; 17 \mathrm{a})$ & 5.837 & 2.877 & 2.7995 & 3.0285 & 7.56 \\
$7-2(60 ; 7 \mathrm{~b})$ & 5.998 & 2.932 & & & \\
$7-2(115 ; 11)$ & 6.192 & 2.926 & 2.8800 & 3.0162 & 4.52 \\
$8-1(44 ; 6)$ & 5.722 & 2.872 & 2.7980 & 3.0155 & 7.21 \\
$8-1(70 ; 9)$ & 5.999 & 2.954 & & & \\
$8-1(80 ; 10)$ & $5.906 \mathrm{~b}$ & 2.945 & & & \\
$8-1(93 ; 11)$ & $5.810^{\mathrm{b}}$ & 2.908 & & & \\
$8-1(145 ; 16)$ & 6.215 & 2.956 & 2.9200 & 3.0265 & 3.52 \\
$9-1(26 ; 5)$ & 5.887 & 2.933 & & & \\
$9-2(67 ; 7)$ & 5.910 & 2.953 & & & \\
$9-3(69 ; 10)$ & $5.583^{\mathrm{b}}$ & 2.908 & & & \\
\hline
\end{tabular}

${ }^{3}$ Determined from mass and length measurements.

Rocks removed from core lab: out of water about 24 hours, before resaturation.

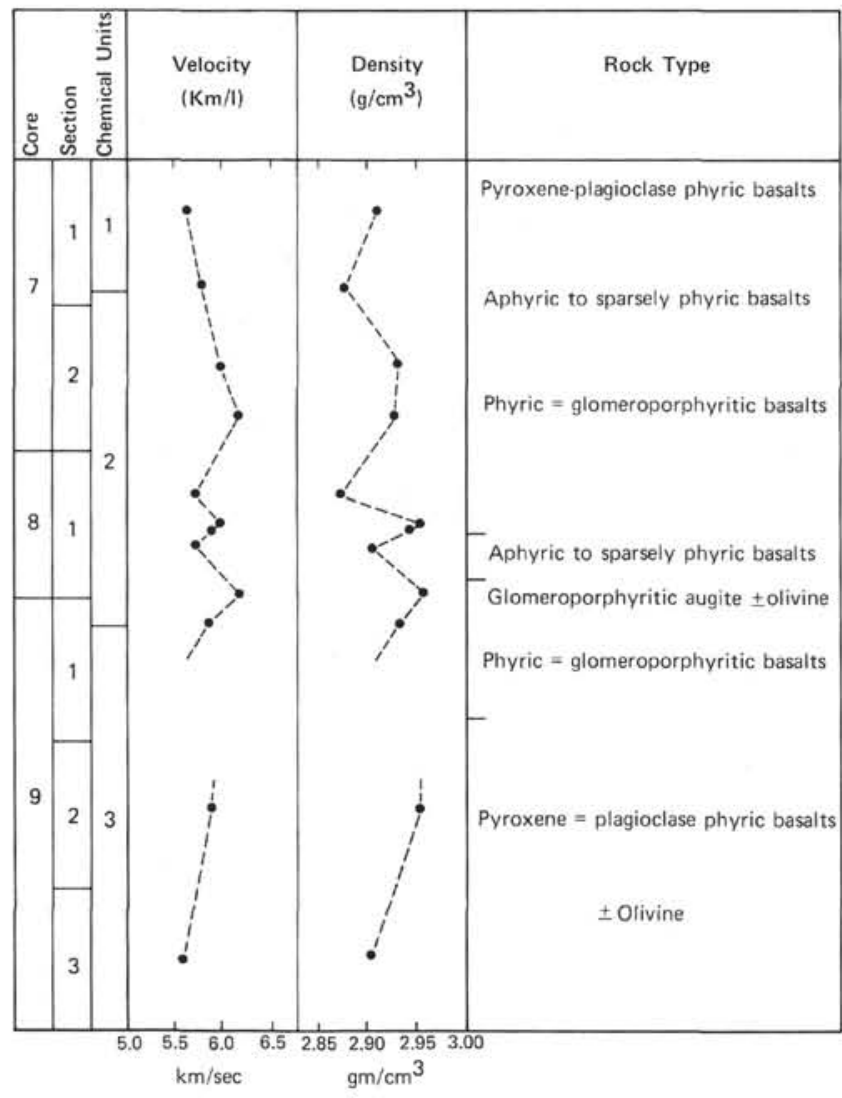

Figure 34. Sonic velocity and density of basalts versus section depth, Hole 425. Each section is 1.5 meters long; each core represents 9.5 meters. The vertical axis therefore represents the location of basalts (spread out with styrofoam spacers) in individual sections, stacked end-on-end.

icates depositing initially and $\mathrm{Fe}-\mathrm{Mn}$ oxides more recently.

These various viewpoints are discussed more thoroughly in Hekinian, Rosendahl, and Natland (this volume). It seems certain, however, that channels of upris- ing hot water and zones of related alteration in basement must either be very narrow and we missed them, or there is no immediate relationship between the location of mounds and subjacent springs of hot water. The position of mounds may be controlled by faults, but the source vents may be diffuse, or well away from particular mounds.

\section{Petrology and Geochemistry of Basement Rocks}

Basement rocks were recovered at all four drill sites south of the Galapagos Spreading Center. The most successful basement hole was Hole 424, which penetrated 45 meters of basalt with a recovery amounting to about 8.45 meters. The basement penetration at the other sites was 14.5 meters (Hole 424B), with 2.35 meters of recovery, to 3 meters (Hole 424C) with 0.48 meters of recovery. The least successful hole as far as basement penetration was concerned was Hole 424A, which penetrated 5.0 meters but produced a recovery of only 0.10 meter of rock.

The basement rocks recovered from these holes are massive basalts varying from coarse- to fine-grained to glassy rocks. Usually the most glassy specimens represent the chilled margins of a cooling unit. On the basis of the degree of crystallinity, several cooling units have been identified at most of the holes. Hole 424 contains at least three cooling units made up mostly of massive flows ( 0.5 to $5 \mathrm{~m}$ thick). Holes $424 \mathrm{~B}$ and $\mathrm{C}$ show thinner cooling units ( $\simeq 0.20$ to $1.5 \mathrm{~m}$ thick) with glassy chilled margins, suggesting the presence of individual pillow lava sequences. Hole $424 \mathrm{~A}$, which has the lowest rock recovery, is made up of fragmented, coarse-grained basaltic rock.

All the rocks recovered from the various sites are plagioclase-pyroxene ferrobasalts with strikingly uniform chemistry. The major variation with depth in the hole is due to textural changes related to the degree of crystallinity. The major textural types observed are hyalopilitic, variolitic, intersertal, and subophitic. The mineralogy of these rocks consists of plagioclase (32-47\%), pyroxene $(15-42 \%)$, and opaques $(6-12 \%)$. Olivine occurs as an occasional constituent $(1 \%)$ at Hole 424 . Only rare phenocrysts of plagioclase occur throughout the various cooling units at all holes. The opaques consist of titanomagnetite and sulfides (pyrite). No mineralized veins or veinlets were observed, and the basement rocks in the area of drilling do not show any obvious signs of hydrothermal alteration. Moreover, very few alteration products $(<3.6 \%)$, such as clay and iron hydroxide material, were observed.

The rocks from Hole 424 are chemically comparable and all are enriched in $\mathrm{Fe}_{2} \mathrm{O}_{3}(14-15 \%$; total $\mathrm{Fe}$ calculated as $\mathrm{FeO})$ and $\mathrm{TiO}_{2}(1.8-1.9 \%)$. The $\mathrm{MgO}$ $4-5 \%)$ and the $\mathrm{K}_{2} \mathrm{O}(0.04-0.15 \%)$ contents are relatively low when compared to the Pt-4 East Pacific Rise basalts. It is interesting that two dredge hauls from near the Galapagos Spreading Center, described by Schilling et al. (1976), show a wider range of $\mathrm{TiO}_{2}(1-2 \%)$ and $\mathrm{FeO} /(\mathrm{MgO}+\mathrm{FeO})$ ratio $(0.45-0.8)$ than those recovered in the four holes of Site 424 . 


\section{Basement Magnetic and Physical Properties}

\section{Site 424}

This site was located very near the transition from the Brunhest normal magnetic epoch to the Matuyama reversed epoch, and a magnetic age of 0.60 to $0.62 \mathrm{~m} . \mathrm{y}$. is assigned to the basement at the Site 424 holes. The fact that some inclination measurements at this site (particularly in Holes 424B and C) deviate substantially from the zero value that should be observed for equatorial basement rocks suggests that some tilting has occurred.

Velocity and density measurements for Hole 424 cluster around values of $5.65 \mathrm{~km} / \mathrm{s}$ and $2.93 \mathrm{~g} / \mathrm{cm}^{3}$. The values for Holes $424 \mathrm{~A}, \mathrm{~B}$, and $\mathrm{C}$ tend to show slightly higher velocities for similar densities, whereas the PT-4 (East Pacific Rise) fabric basalts tend to show lower densities for similar velocities. For rocks of similar freshness, we take this to mean that the Galapagos basalts are relatively more enriched in iron (and opaque minerals) than their East Pacific Rise counterparts.

\section{Hole 425}

This was drilled about $62 \mathrm{~km}$ north of the Galapagos Spreading Center on anomaly 2, which corresponds to slightly more than 1.8-m.y.-old crust using Heirtzler's scale of anomaly patterns for this area. Basement ages based on biostratigraphy range between 1.6 and $1.8 \mathrm{Ma}$. Sedimentation rates were about 40 meters/ $\mathrm{Ma}$, until 0.4 m.y. ago when they more than doubled. The hole was placed in an area with relatively high heat flow of about $5 \mu \mathrm{cal} / \mathrm{cm}^{2} \mathrm{~s}$ according to observations of Sclater and Klitgord (1973).

The total penetration at this site was 110 meters, of which 28.5 meters penetrated into the basaltic basement. The total recovery was 81.5 meters, of which 5.76 meters of rocks was recovered.

The seismic profile record in the Hole 425 area shows about 0.11 seconds (two-way reflection time) of sediment. The same profile made along the Galapagos spreading ridges prior to reaching the site shows the presence of fault-block structures. These fault blocks range from less than $1 \mathrm{~km}$ to about $4 \mathrm{~km}$ wide. They are asymmetrical and have the strongest dipping oriented towards the spreading axis; the outward limbs facing away from the spreading axis are gently sloped. Many of these asymmetrical fault blocks are separated from each other by small graben-like features of less than 1 $\mathrm{km}$ width. The seismic profile record shows the presence of some sediment filling in these graben-like features located between the steep sides of the asymmetric fault blocks. Similar features were also recognized by Klitgord and Mudie (1973) using deep-tow survey gear in the same general area.

Within the first $7 \mathrm{~km}$ of both sides of the central spreading axis, the individual asymmetrical fault blocks are relatively small (less than $1 \mathrm{~km}$ wide) and show smaller offsets along their fault scarps when compared with others farther away from the spreading axis. The first blanket of sediment detectable using the shipboard seismic profile occurs within about $15 \mathrm{~km}$ of the axis. A small graben-like structure which has faulted the sediments occurs at about $30 \mathrm{~km}$ from the axis. The asymmetric faulting of the individual blocks has also affected the sediment blanket. Graben-like structures are scattered along the transect across the Galapagos spreading area. The orderly pattern of the fault-plan orientation with respect to the active spreading axis suggests that tilting and down-faulting related to symmetrical spreading have given rise to the fault-block structures. The basement complex drilled at Hole 425 is tilted $30^{\circ}$ to the south toward the spreading axis $65 \mathrm{~km}$ away. The top of this down-faulted block is buried by flat-lying sediment.

After penetrating 28.5 meters into basement, 8 meters of basaltic rocks was recovered. This comprises eight lithologic units, three chemical units, and four magnetic units. Some of the core sections recovered are sufficiently continuous to give a good impression of lithological variations. Whereas the mineralogical variation is limited to the various concentrations of plagioclase, clinopyroxene, and olivine, the textural changes are of prime interest in detecting different cooling sequences. The degree of rock crystallinity is related to grain size encountered within the various portions of the same cooling unit. Typically there is a gradual passage from glassy chilled margins to fine-grained basalts with interstitial glass, thence to coarse-grained crystalline zones of doleritic aspect. The thicknesses of individual cooling units varying in this manner range from $90 \mathrm{~cm}$ to more than 3 meters. The topmost cooling unit continuously cored has a thickness of about 3 meters. It consists of a chilled margin about $20 \mathrm{~cm}$ thick grading first into very fine grained material, thence to mediumgrained, and finally to coarser grained basalt located at the bottom of the unit. The lower portion of the unit was not recovered. This particular unit is also characterized by an increase of sonic velocity downward. Thus the sonic velocity near the chilled margin is $5.62 \mathrm{~km} / \mathrm{s}$ and it increases up to $6.12 \mathrm{~km} / \mathrm{s}$ in coarser portions of the unit.

Because of drilling limitations, such as the narrow width of the cores $(6 \mathrm{~cm})$ and the discontinuous recovery, we do not know if these rocks are intrusive or extrusive. However, the chilled margins encountered in these various cooling units do not show any sharp textural discontinuity between their glassy rims and their immediate interior. Indeed, it seems that there is a limited glassy matrix, and the chilled margin of about $20-30 \mathrm{~cm}$ thick consists mainly of a dark mesostasis with microlites of various minerals. True pillow lavas of extrusive nature instead show a thin $(<2 \mathrm{~cm}$ thick) glassy rim ( $80-90 \%$ glass). The chilled margin associated with the cooling units of Hole 425 are also characterized by the decrease in size of their titanomagnetite minerals $(<2 \mu \mathrm{m})$.

Modal analyses of the various types of rocks encountered indicate a strong enrichment of plagioclase and pyroxene, while olivine occurs only in subordinate amounts. Based on the early-formed mineral phases and their relative proportions, the rocks found in the various cooling units are classified as follows: 
1) Plagioclase-pyroxene basalt with 40 to 50 per cent plagioclase and 37 to 50 percent pyroxene.

2) Plagioclase-pyroxene-olivine basalt with 18 to 42 per cent plagioclase, 3 to 46 per cent clinopyroxene, and less than 1 per cent olivine.

3) Moderate phyric plagioclase basalt with about 60 per cent of total plagioclase, of which about 15 per cent is phenocryst and 36 per cent clinopyroxene.

Although plagioclase-pyroxene-olivine basalts alternate stratigraphically with plagioclase-pyroxene-basalts, moderately phyric plagioclase basalt was encountered only once in the middle of the recovered section.

Chemically, the basalts are moderately fractionated mid-ocean ridge tholeiites; none is very enriched in iron. The uppermost chemical unit is the most fractionated. The basalts all have lower $\mathrm{K}_{2} \mathrm{O}, \mathrm{TiO}_{2}, \mathrm{P}_{2} \mathrm{O}_{5}$, and $\mathrm{Zr}$ than East Pacific Rise basalts (e.g., Srivastava et al., this volume).

Of all the basalts cored at Site 424 and Hole 425, only at the latter site is there any evidence for hydrothermal alteration. This is manifested by more extensive alteration, and localized veining (fracture filling) with green clays optically similar to the sediments at Site 424, iron oxyhydroxides, and pyrite. Altogether, though, alteration is not very advanced.

\section{REFERENCES}

Anderson, R. N., Clague, D. A., Klitgord, K. D., Marshall, M., and Nishimori, R. K., 1975. Magnetic and petrologic variations along the Galapagos spreading center and their relation to the Galapagos melting anomaly. Geol. Soc. Am. Bull., v. 86, p. 683-694.

Anderson, R. N., Moore, G., Schilt, S., Cardwell, R., Trehu, A., and Vacquier, V., 1976. Heat flow near a fossil ridge on the north flank of the Galapagos Spreading Center. J. Geophys. Res., v. 81 , p. $1828-1838$.

Bonatti, E., Honnorez, J., Joensuu, O., and Rydell, H. S., 1972. Submarine iron deposits from the Mediterranean Sea. In Stanley, D. J. (Ed.), Symposium Volume on Sedimentation in the Mediterranean Sea, Eighth International Sedimentology Congress, Heidelberg, 1971, p. 701-710.

Bonatti, E., and Joensuu, O., 1966. Deep-sea iron deposits from the South Pacific. Science, v. 154, p. 643-645.

Bunch, T. E. and LaBorde, R., 1976. Mineralogy and composition of selected basalts from DSDP Leg 34. In Yeats, R. S., Hart, S. R., et al., Initial Reports of the Deep Sea Drilling Project, v. 34: Washington (U. S. Government Printing Office).

Clague, D. A., and Bunch, T. E., 1976. Formation of ferrobasalt at East Pacific midocean spreading centres. $J$. Geophys. Res., v. 81, p. 4247-4256.

Corliss, J. B., Lyle, M., Dymond, J., and Crane, K., 1978. The chemistry of hydrothermal mounds near the Galapagos Rift. Earth Planet. Sci. Lett., v. 40, p. 12-24.
Cronan, D. S., 1972. Regional geochemistry of ferromanganese nodules in the world ocean. In Horn, D. R. (Ed.) Ferromanganese Deposits on the Ocean Floor, Lamont-Doherty Geological Observatory, Palisades, N.Y., p. 19-30. , 1975. Geological and geochemical factors determining the variability of marine manganese nodules. 3rd Oceanol. Internat., Brighton, p. 118-120.

Detrick, R. S., and Lynn, W. S., 1975. The origin of highamplitude magnetic anomalies at the intersection of the Juan de Fuca Ridge and Blanco Fracture Zone. Earth Planet. Sci. Lett., v. 26, p. 105-113.

Dinkelman, M. G., 1973. Radiolarian stratigraphy: Leg 16, Deep Sea Drilling Project. In van Andel, Tj. H., Heath, G. R., et al., Initial Reports of the Deep Sea Drilling Project, v. 16; Washington (U. S. Government Printing Office) p. 747-814.

Dymond, J., Corliss, J., and Stillinger, R., 1976. Chemical composition and metal accumulation rates of metalliferous sediments from Sites 319, 320, and 321. In Yeats, R. S., Hart, S. R., et al., Initial Reports of the Deep Sea Drilling Project, v. 34: Washington (U. S. Government Printing Office), p. 575-588.

Hey, R. N., 1977. Tectonic evolution of the Cocos Nazca spreading center. Geol. Soc. Am. Bull., v. 88, p. 14041420.

Hoffert, M., Perseil, A., Hekinian, R., Choukroune, P., Needham, H. D., Francheteau, J., and LePichon, X., 1978. Hydrothermal deposits sampled by diving saucer in transform fault " $\mathrm{A}$ " near $37^{\circ} \mathrm{N}$ on the mid-atlantic ridge, Famous area. Oceanol. Acta, 1, v. 1, p. 73-86.

Kay, R., Hubbard, N. J., and Gast, P. W., 1970. Chemical characteristics and origin of oceanic ridge volcanic rocks. $J$. Geophys. Res., v. 75(8), p. 1585-1613.

Kempe, D. R. C., 1976. Petrological studies on DSDP Leg 34 basalts, Nazca Plate, eastern Pacific Ocean, In Hart, R. S., Yeats, S. R., et al., Initial Reports of the Deep Sea Drilling Project, v. 34: Washington (U. S. Government Printing Office), p. 189-214.

Klitgord, K. D., and Mudie, J. D., 1974. The Galapagos Spreading Centre: A near-bottom geophysical survey. Geophys. J. Roy. Astron. Soc., v. 38, p. 563-586.

Lonsdale, P., 1977. Deep-tow observations at the Mounds Abyssal Hydrothermal Field, Galapagos Rift. Earth Planet. Sci. Lett., v. 36, p. 92-110.

Schilling, J.-G., Anderson, R. N., and Vogt, P., 1976. Rare earth, $\mathrm{Fe}$ and $\mathrm{Ti}$ variations along the Galapagos spreading centre and their relationship to the Galapagos mantle plume. Nature, v. 261, p. 108-113.

Sclater, J. G., and Klitgord, K. D., 1973. A detailed heat flow, topographic and magnetic survey across the Galapagos spreading center at $86^{\circ} \mathrm{W}$. J. Geophys. Res., v. 78, p. 6951-6975.

Sclater, J. G., von Herzen, R. P., Williams, D. L., Anderson, R. N., and Klitgord, K., 1974. The Galapagos Spreading Center: Heat-flow low on the North Flank. Geophys. J. Roy. Astron. Soc., v. 38, p. 609-626.

Williams, D. L., von Herzen, R. P., Sclater, J. G., and Anderson, R. N., 1974. The Galapagos Spreading Centre: Lithospheric cooling and hydrothermal circulation. Ibid., v. 38, p. 587-608. 


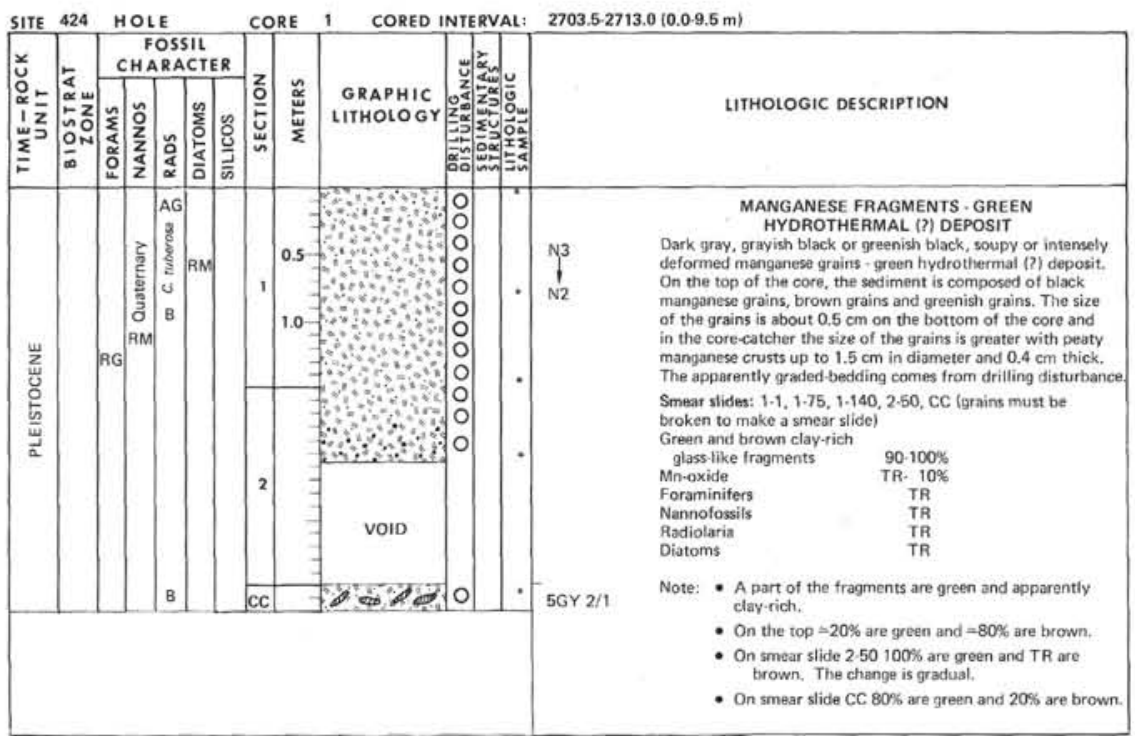



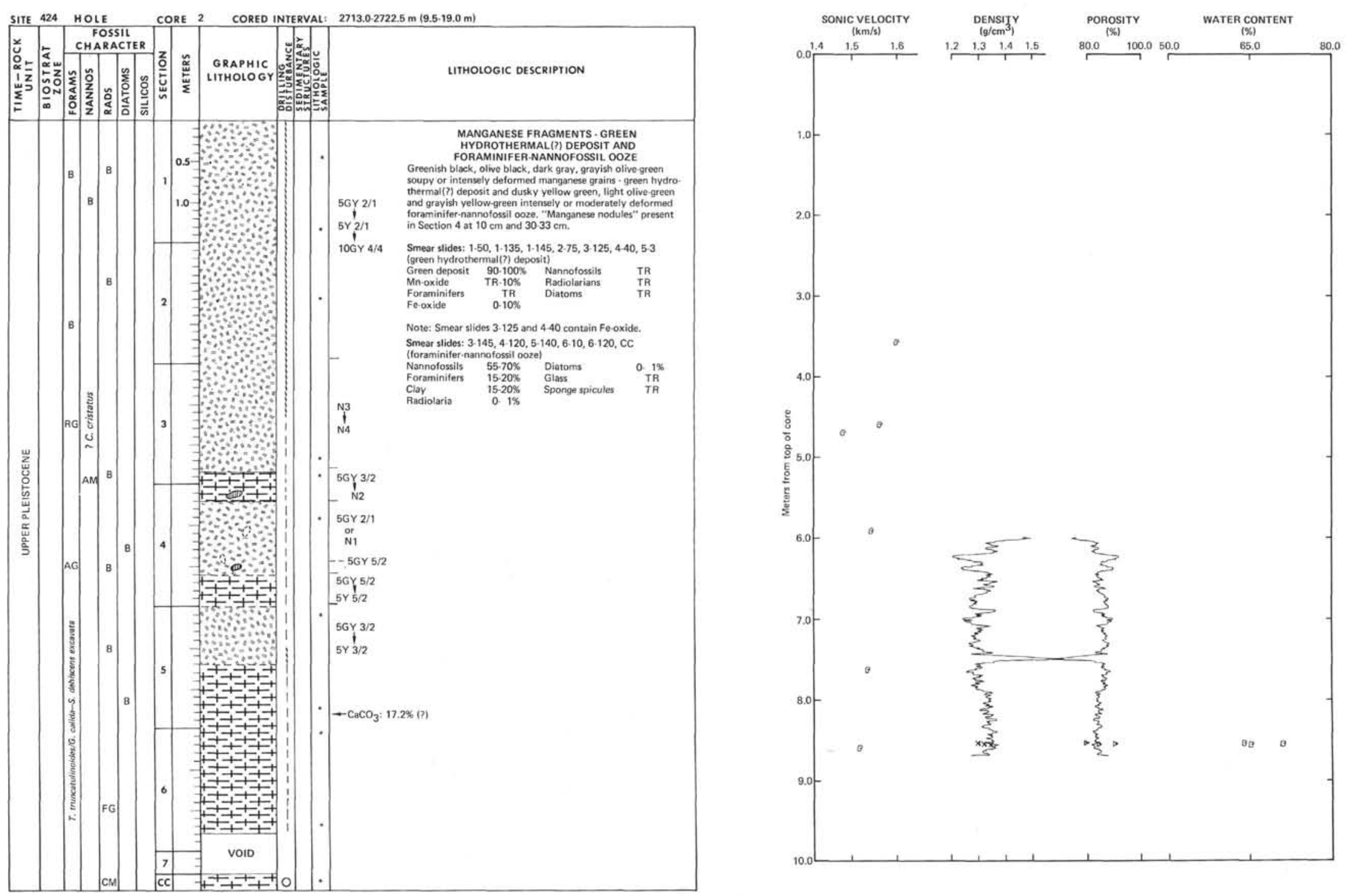

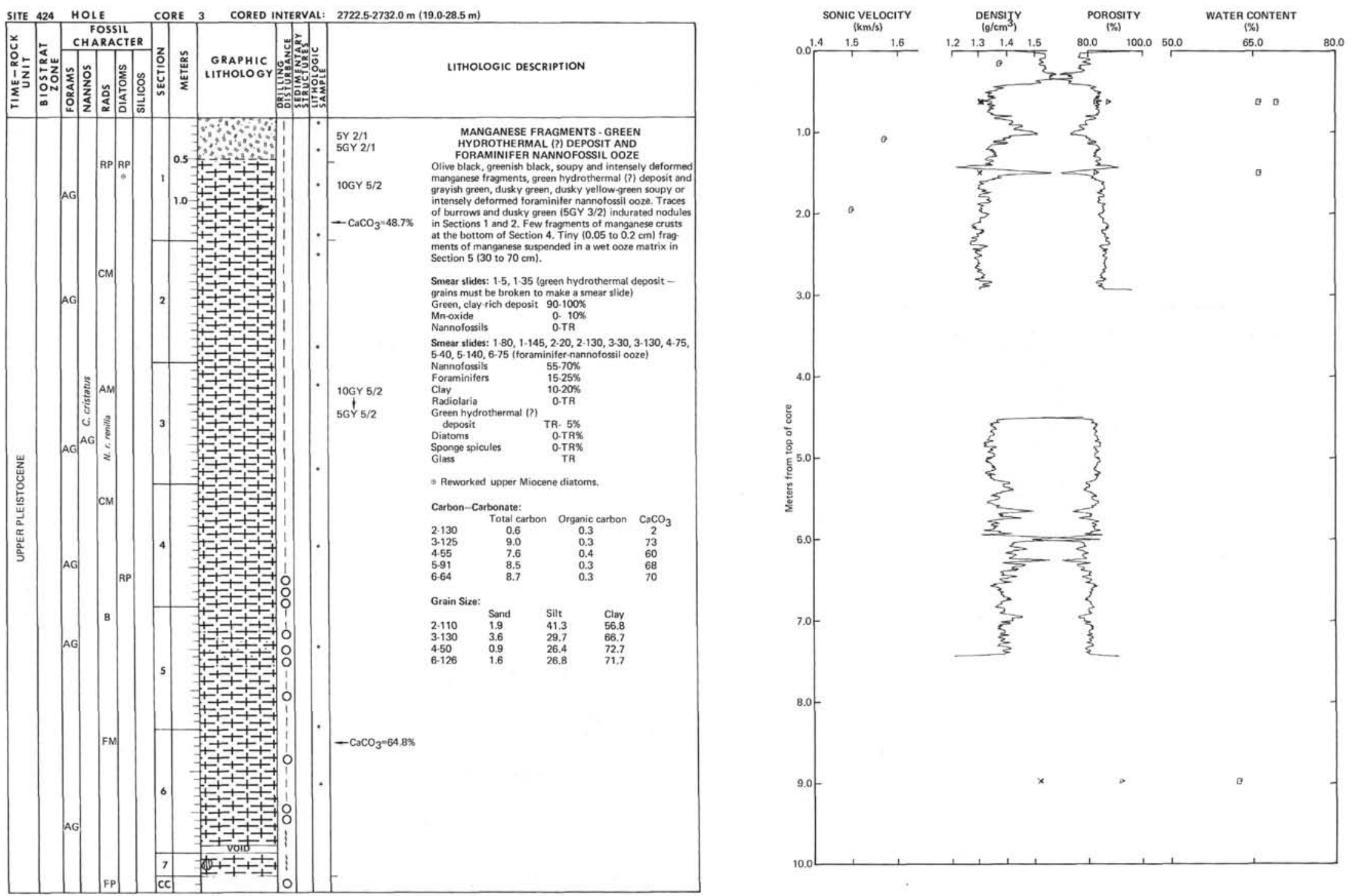

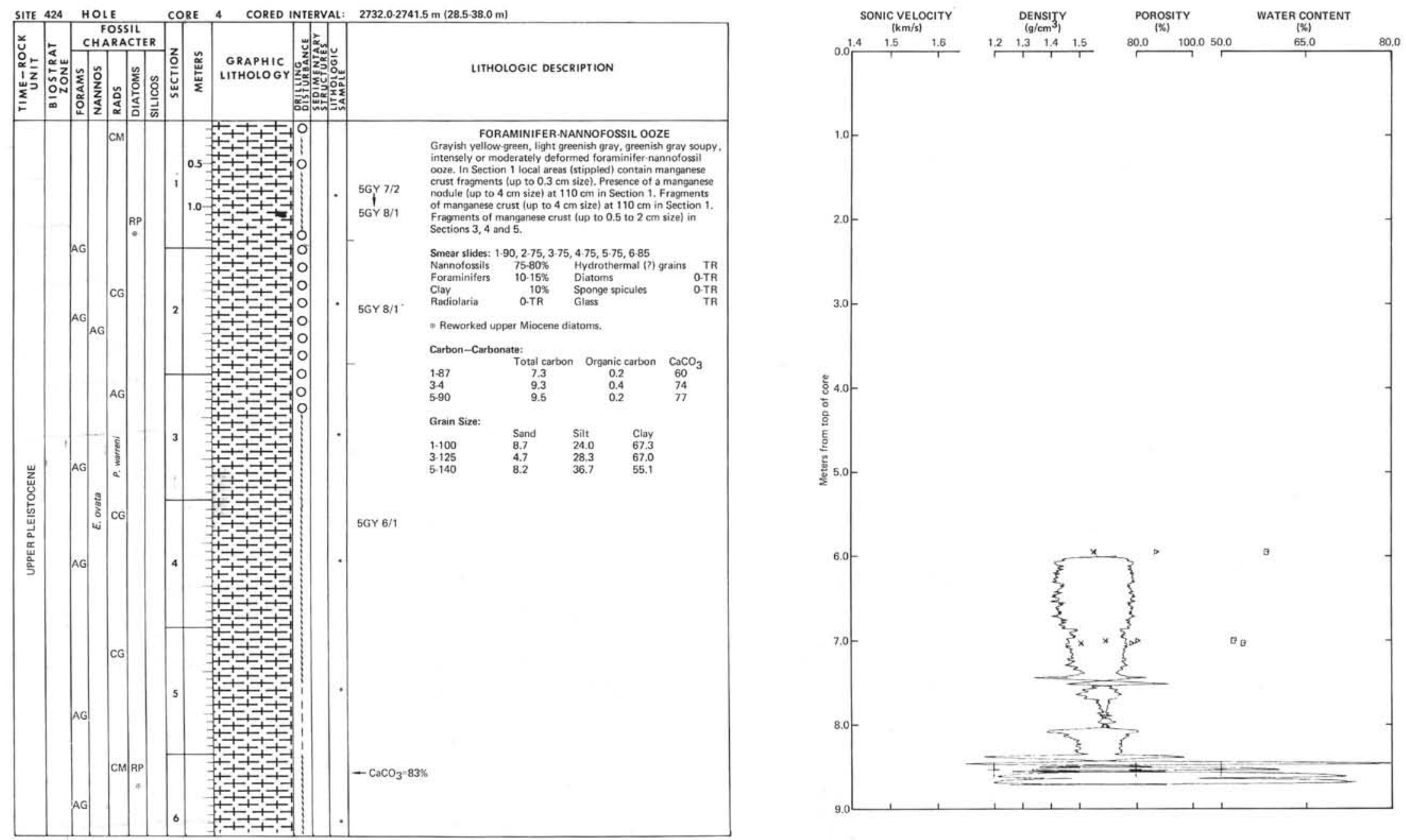


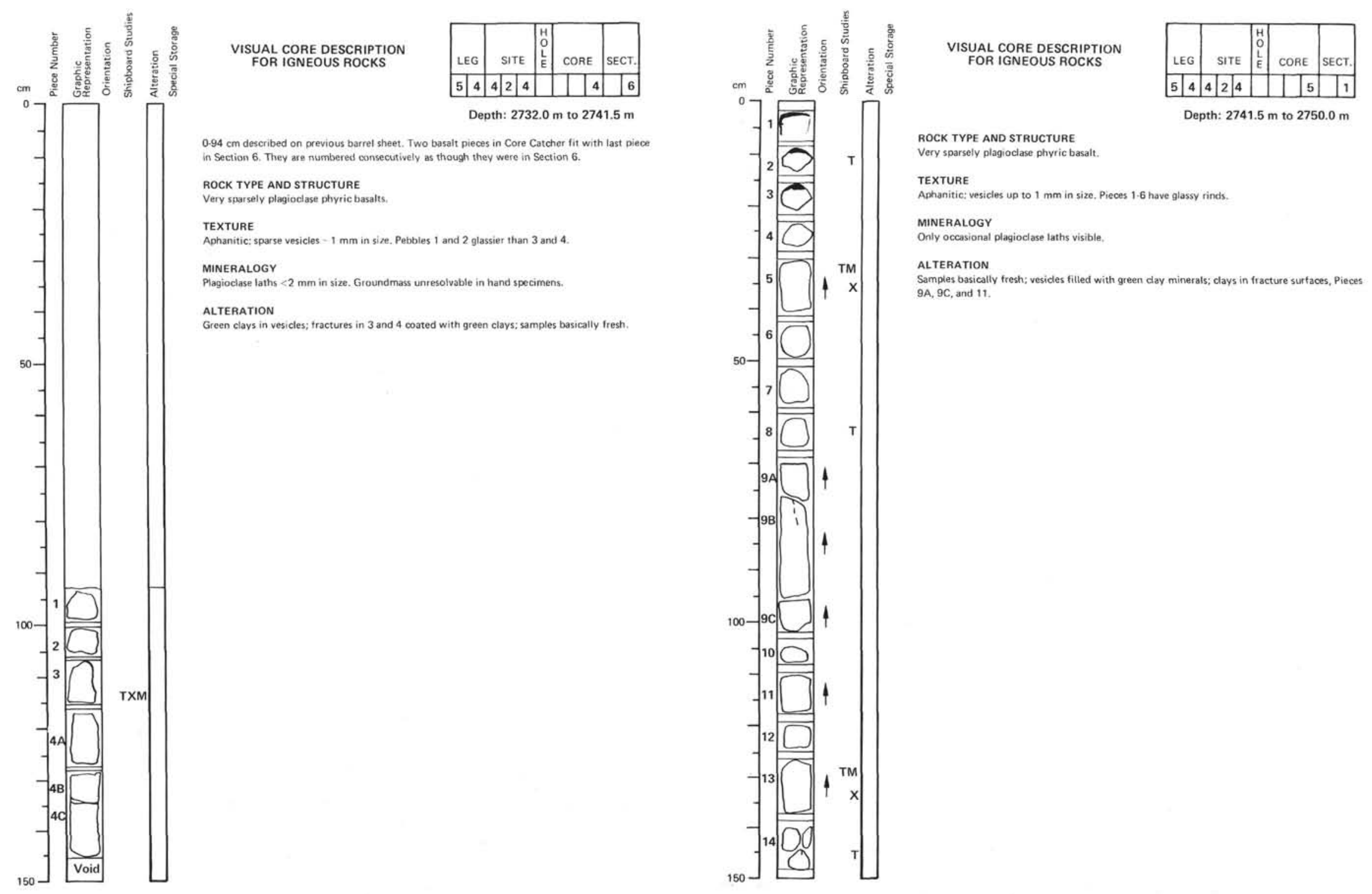



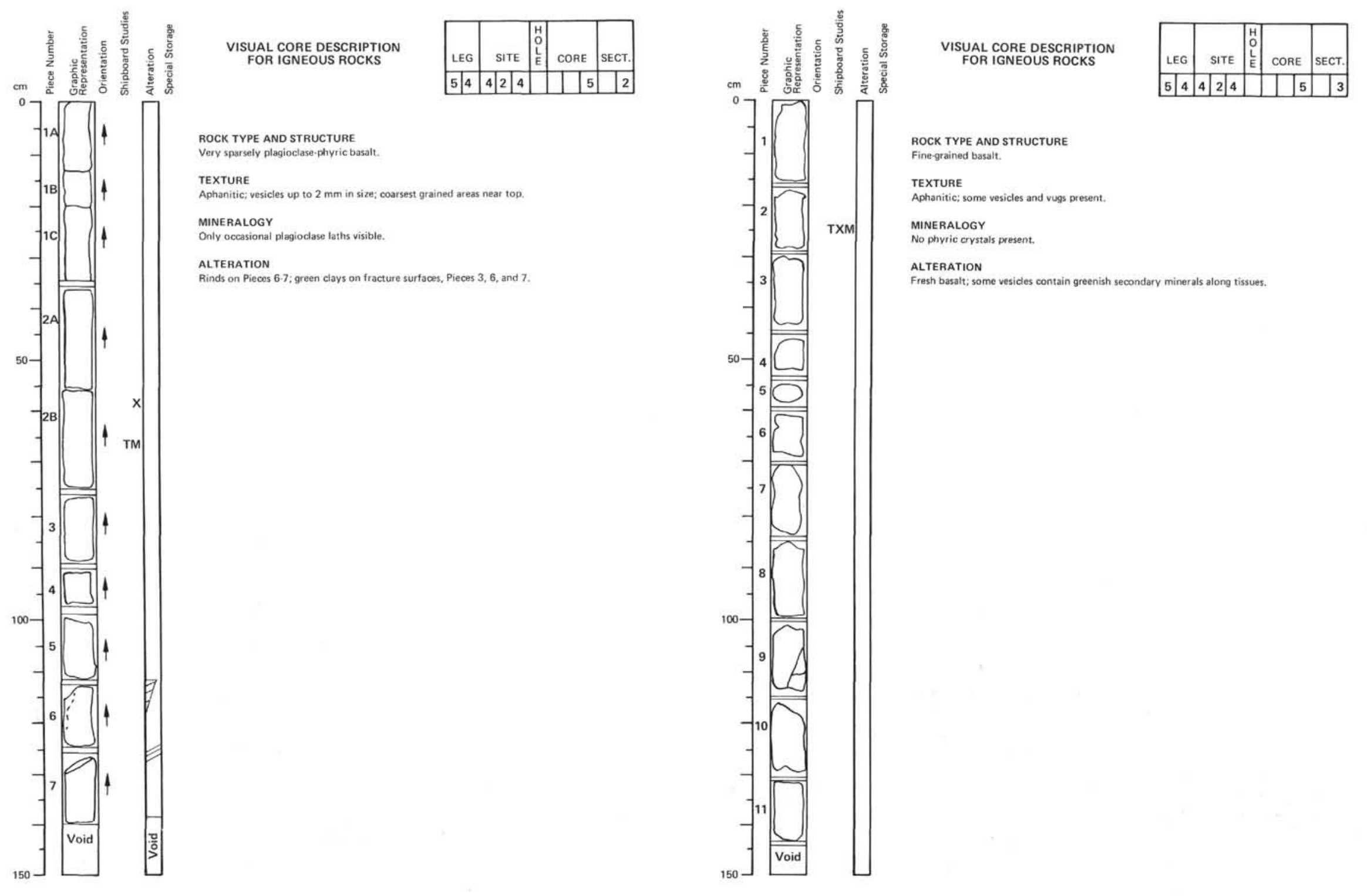


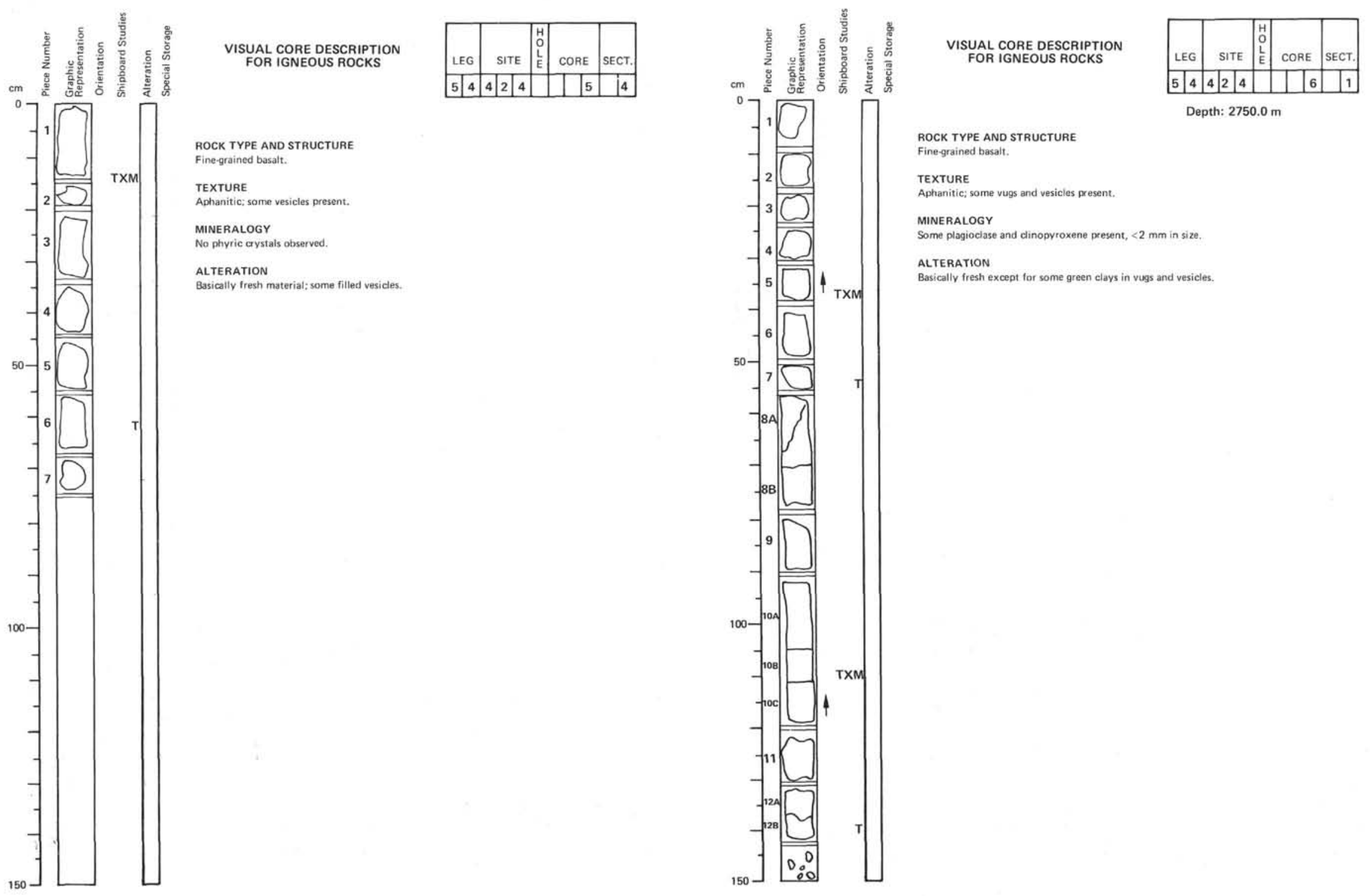




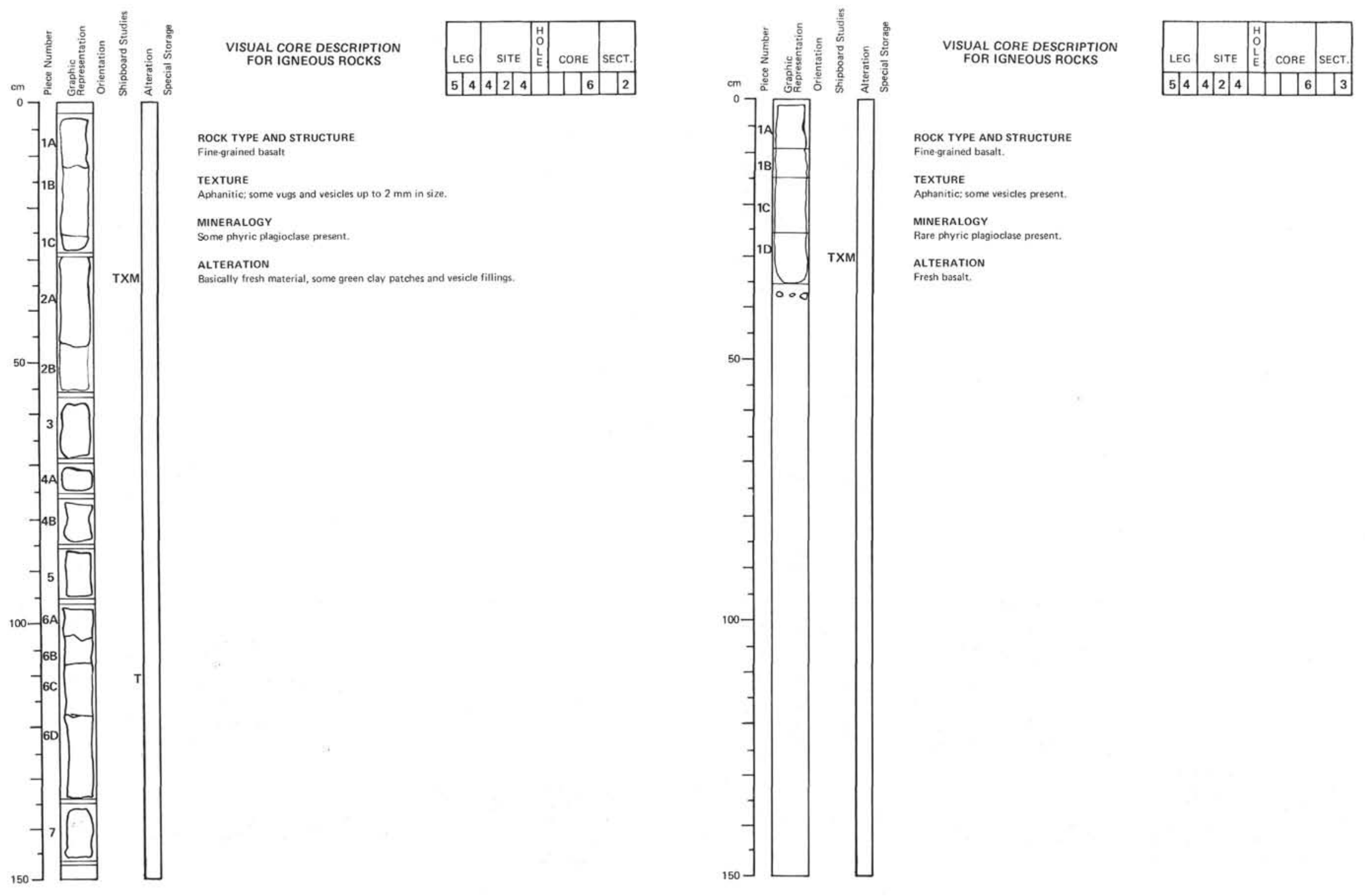




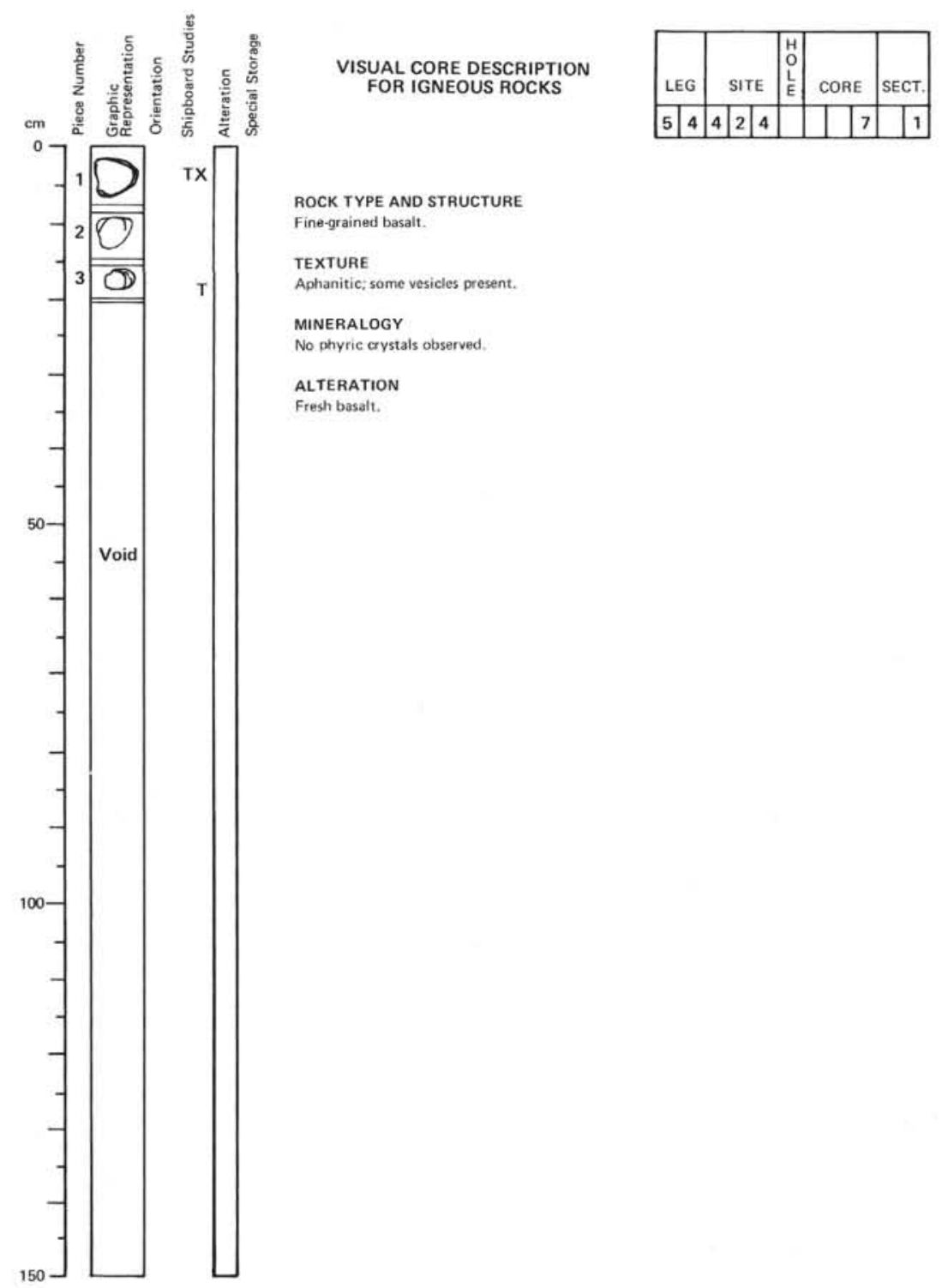




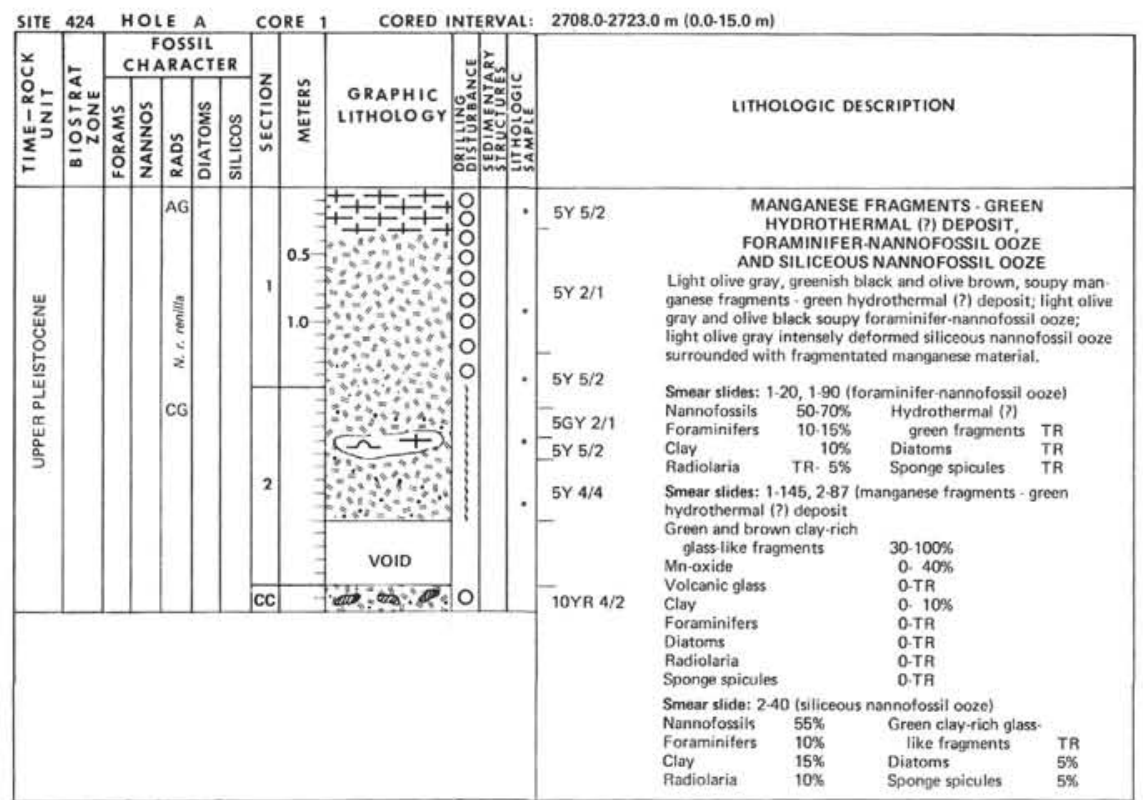

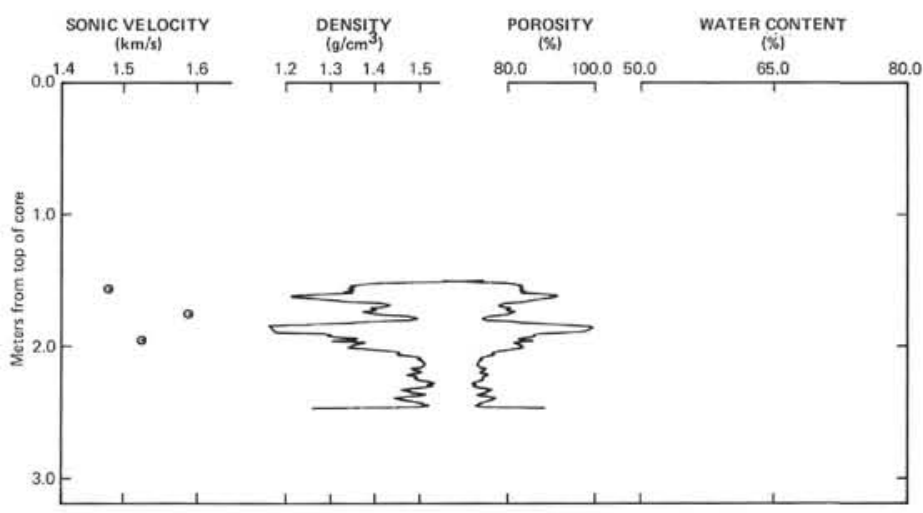



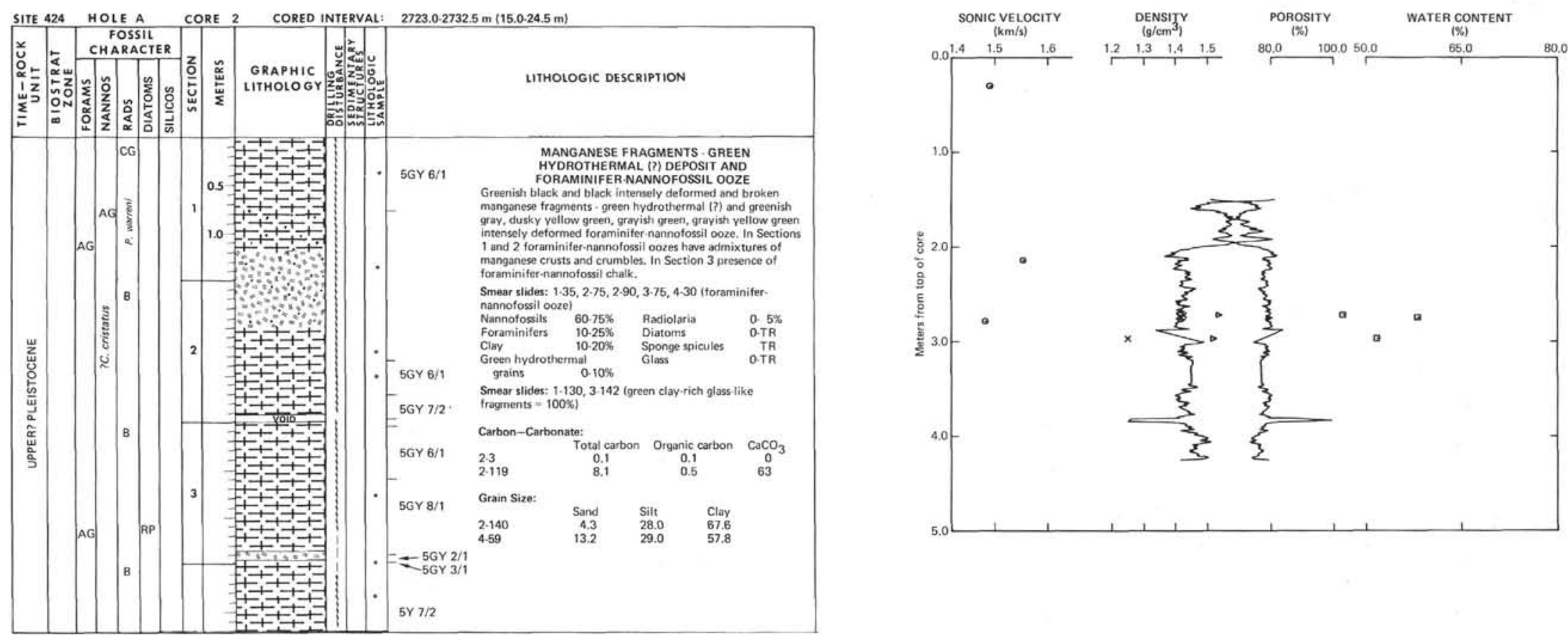


\begin{tabular}{l|l} 
SITE & 24
\end{tabular}

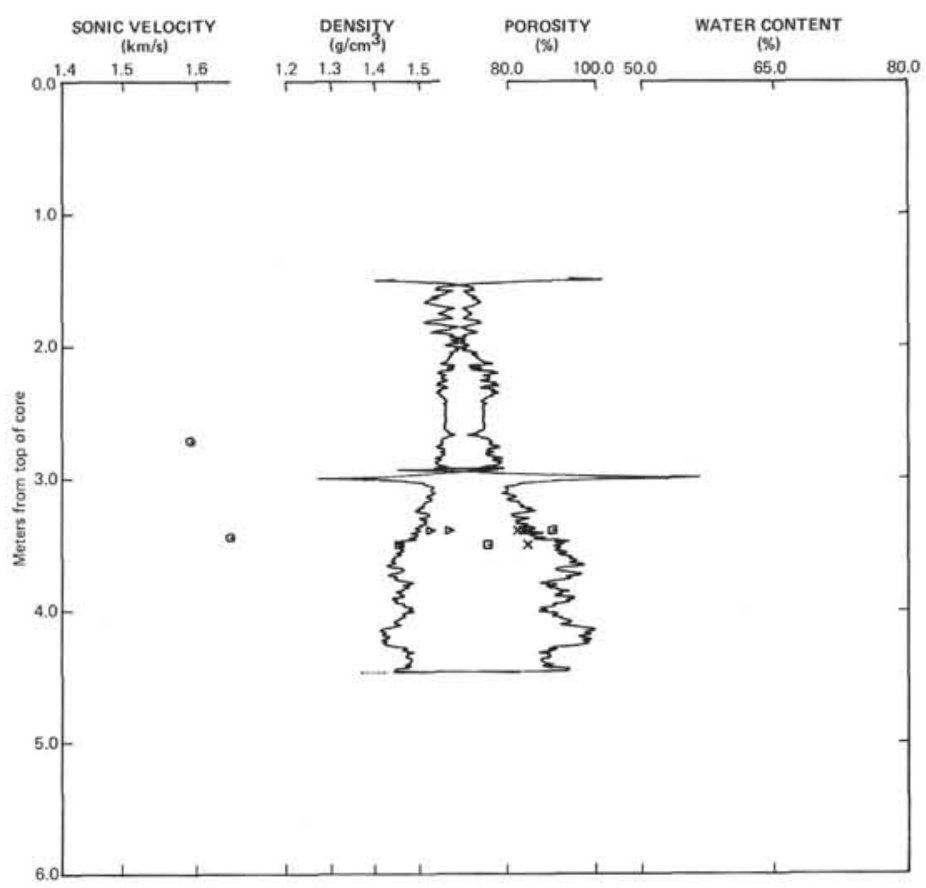



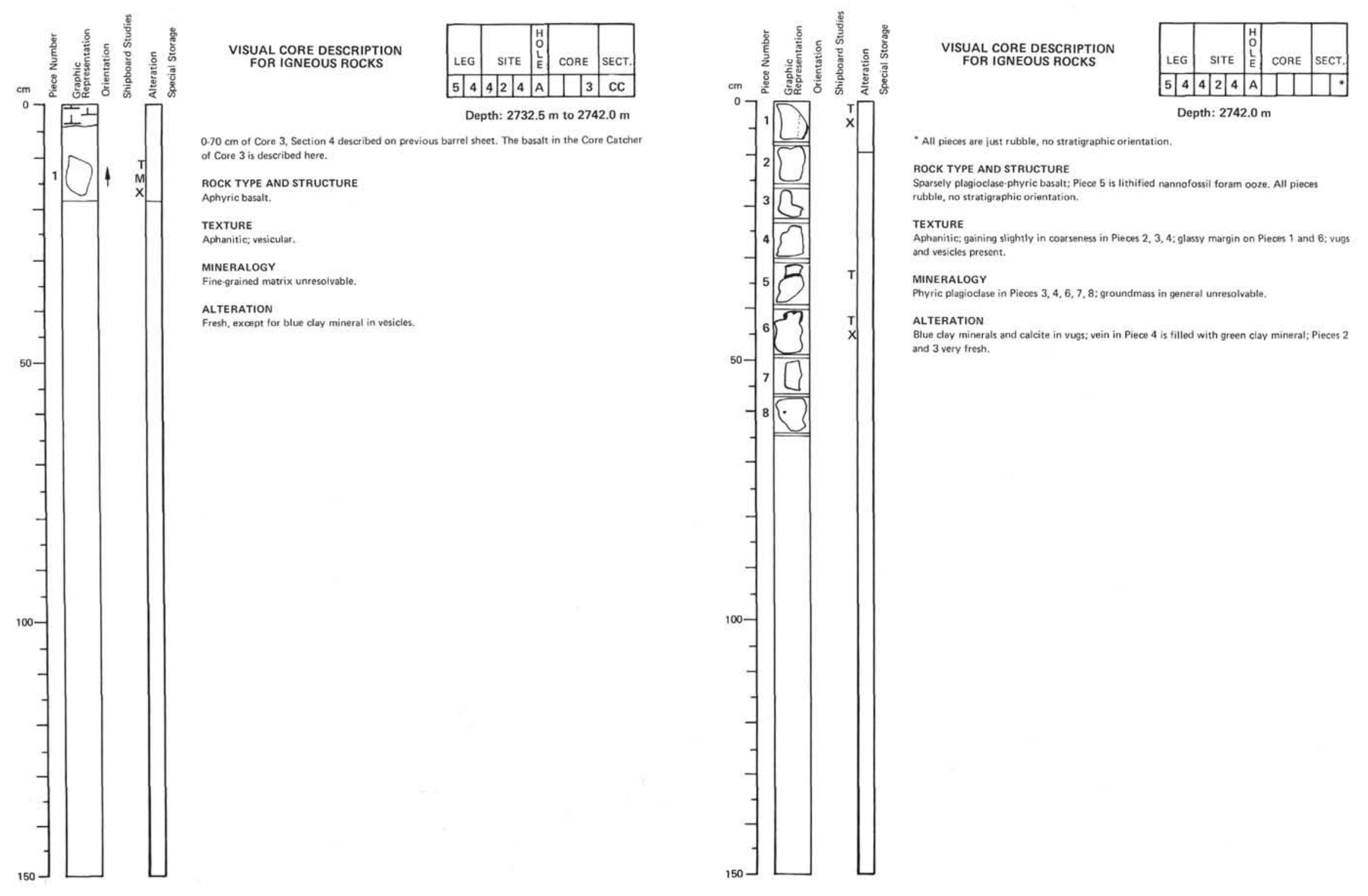


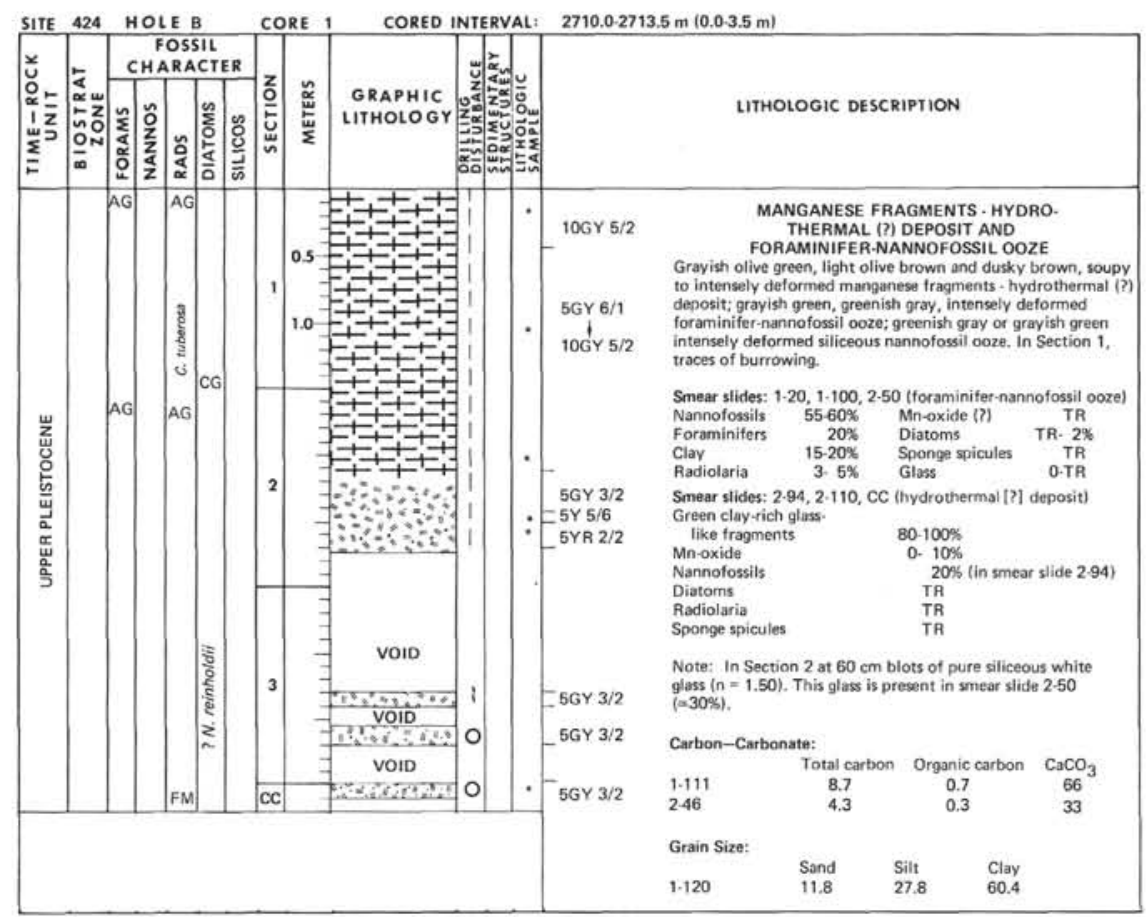

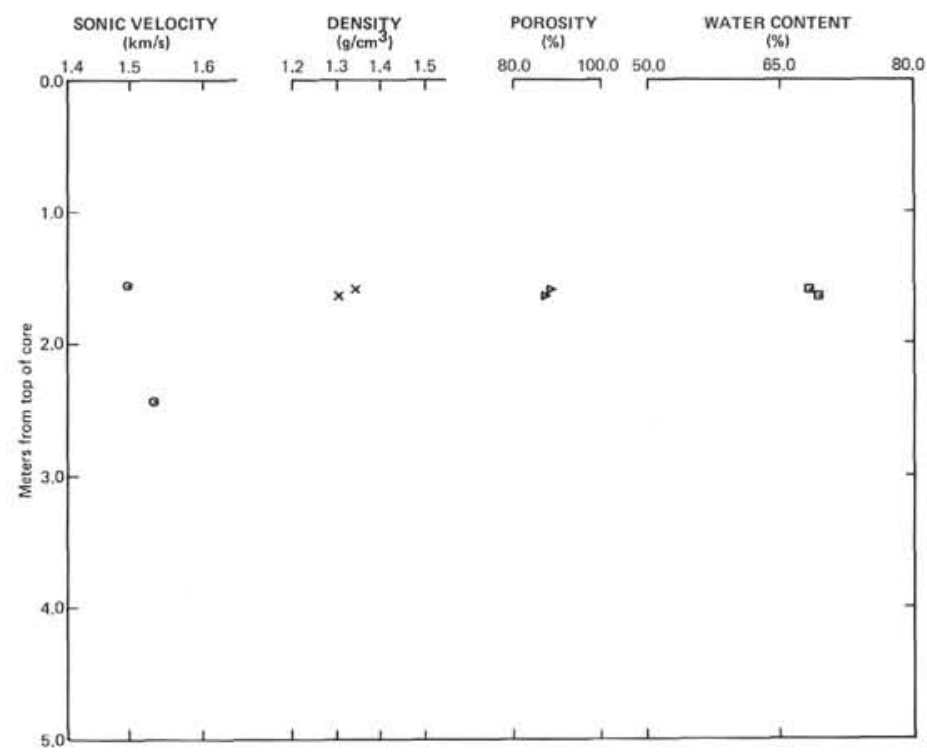




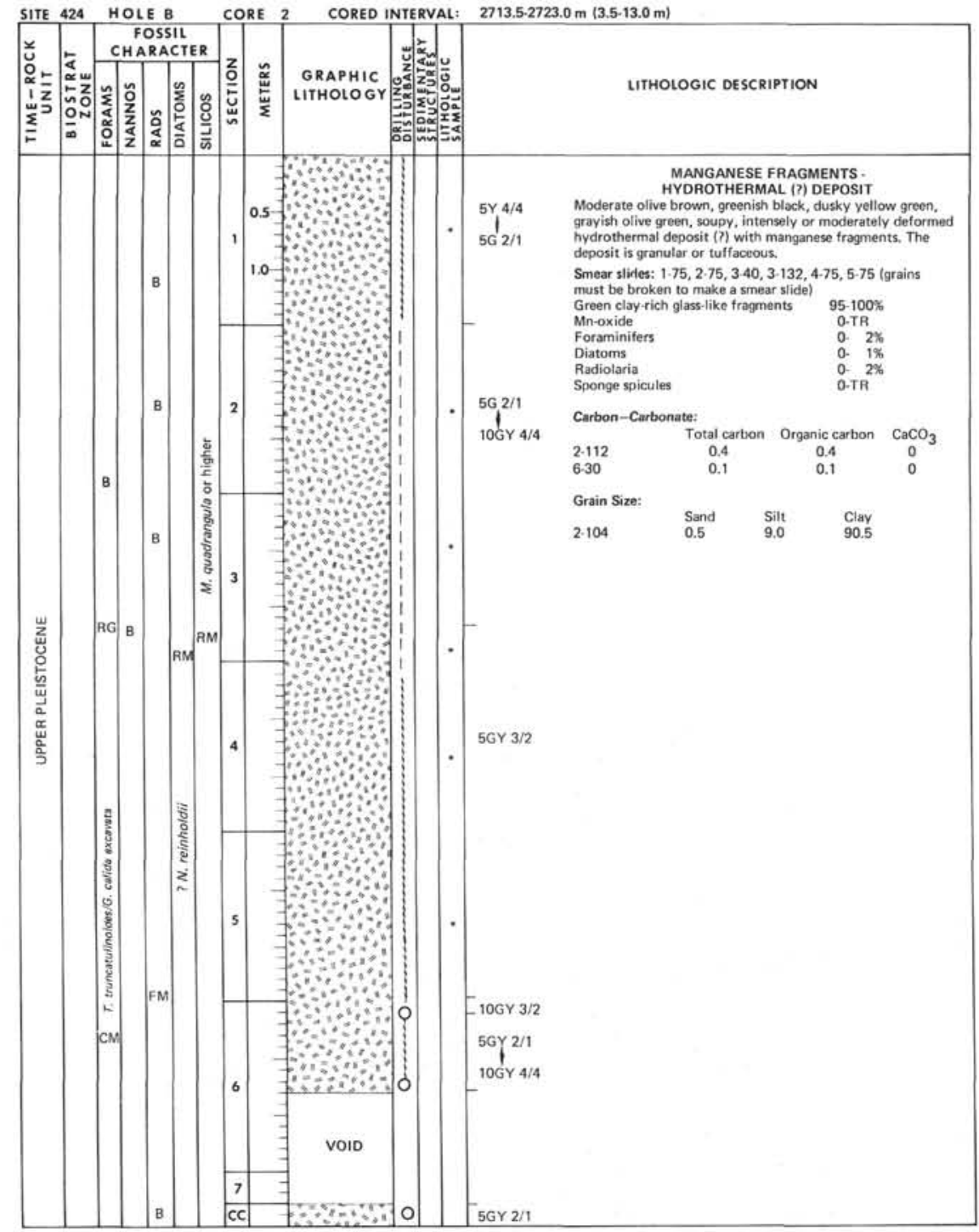




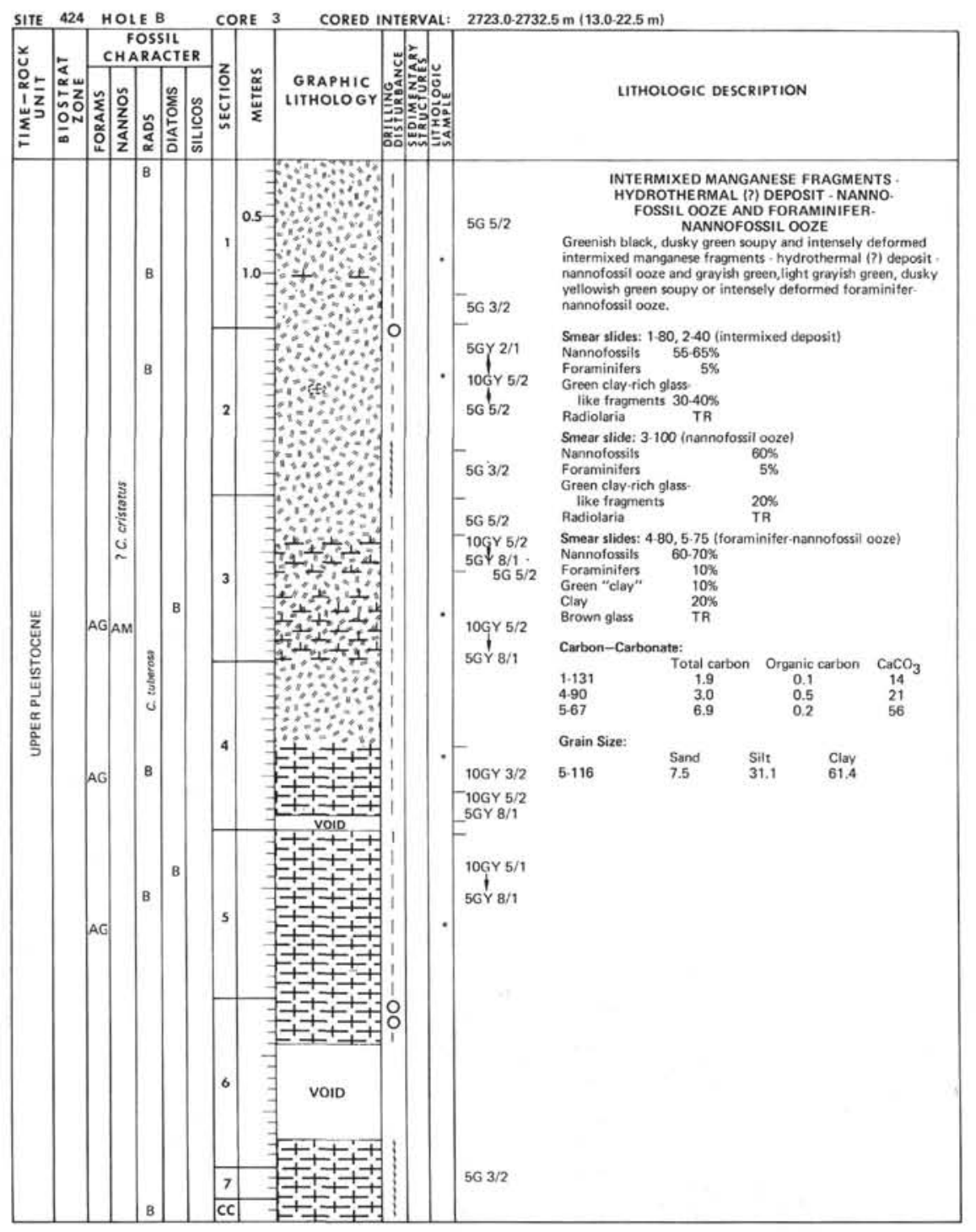

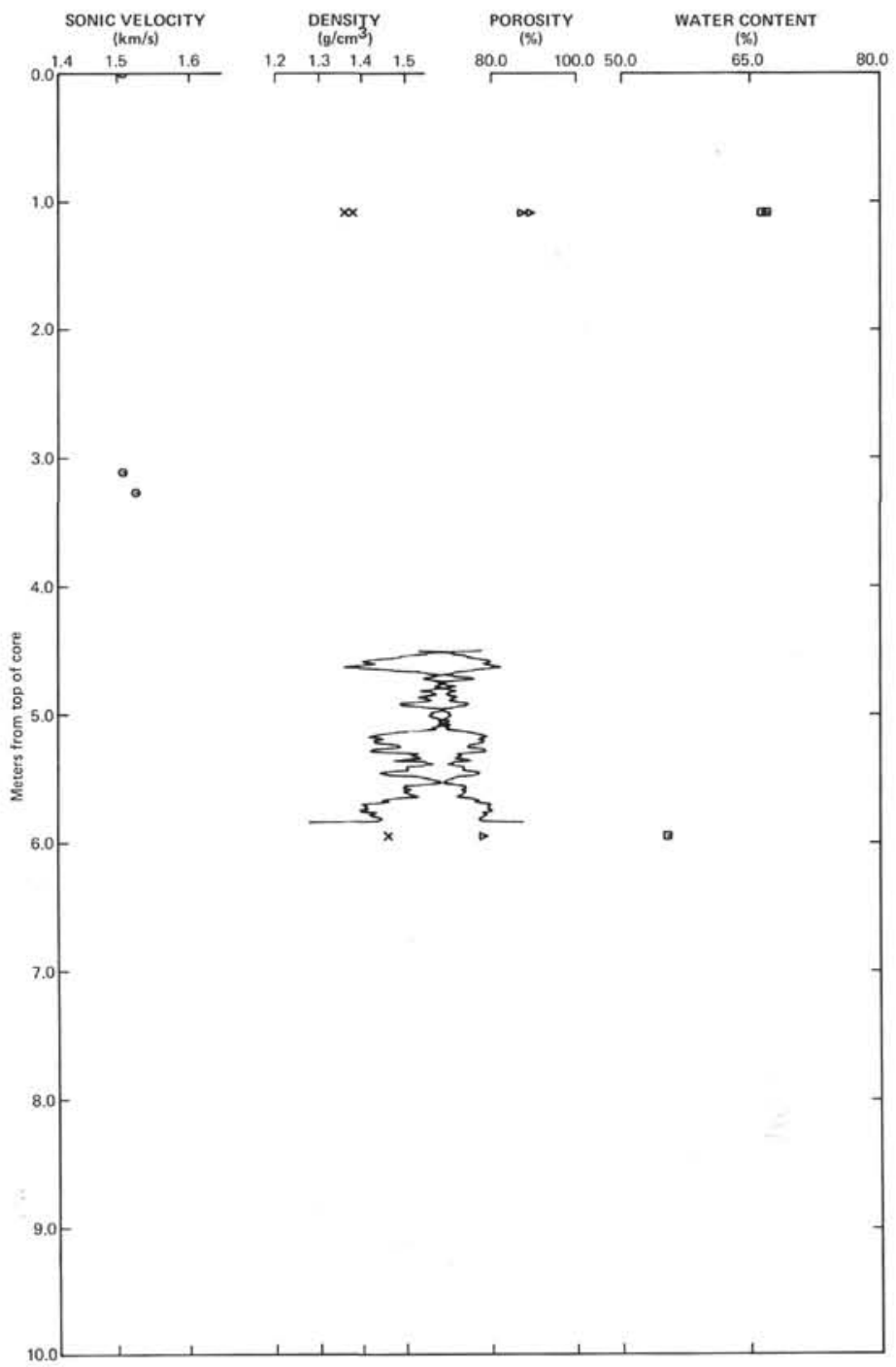



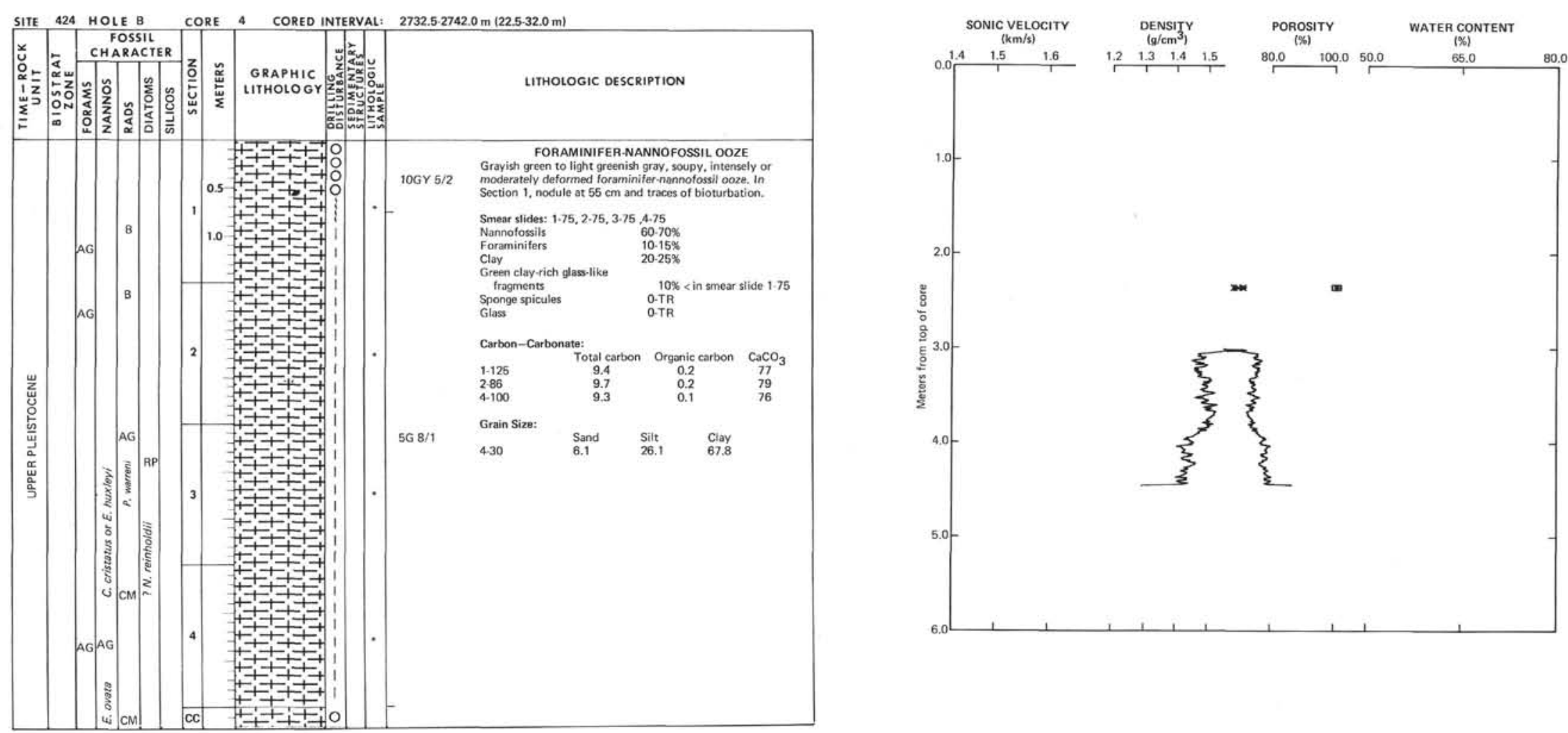


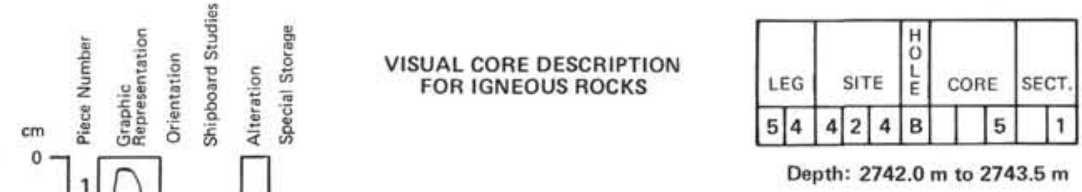

ROCK TYPE AND STRUCTURE

TEXTURE

TEXTUnE areas on Piece 2; vesiclos present.

MineraLogy

Plagioclase phenocrysts present in most pieces; sulfides visible in Piece 2; clinopyroxene in Pieces 3 and 14.

ALTERATION

Most pices fresh; some vesicles filled with zeolite and blue clay mineral.

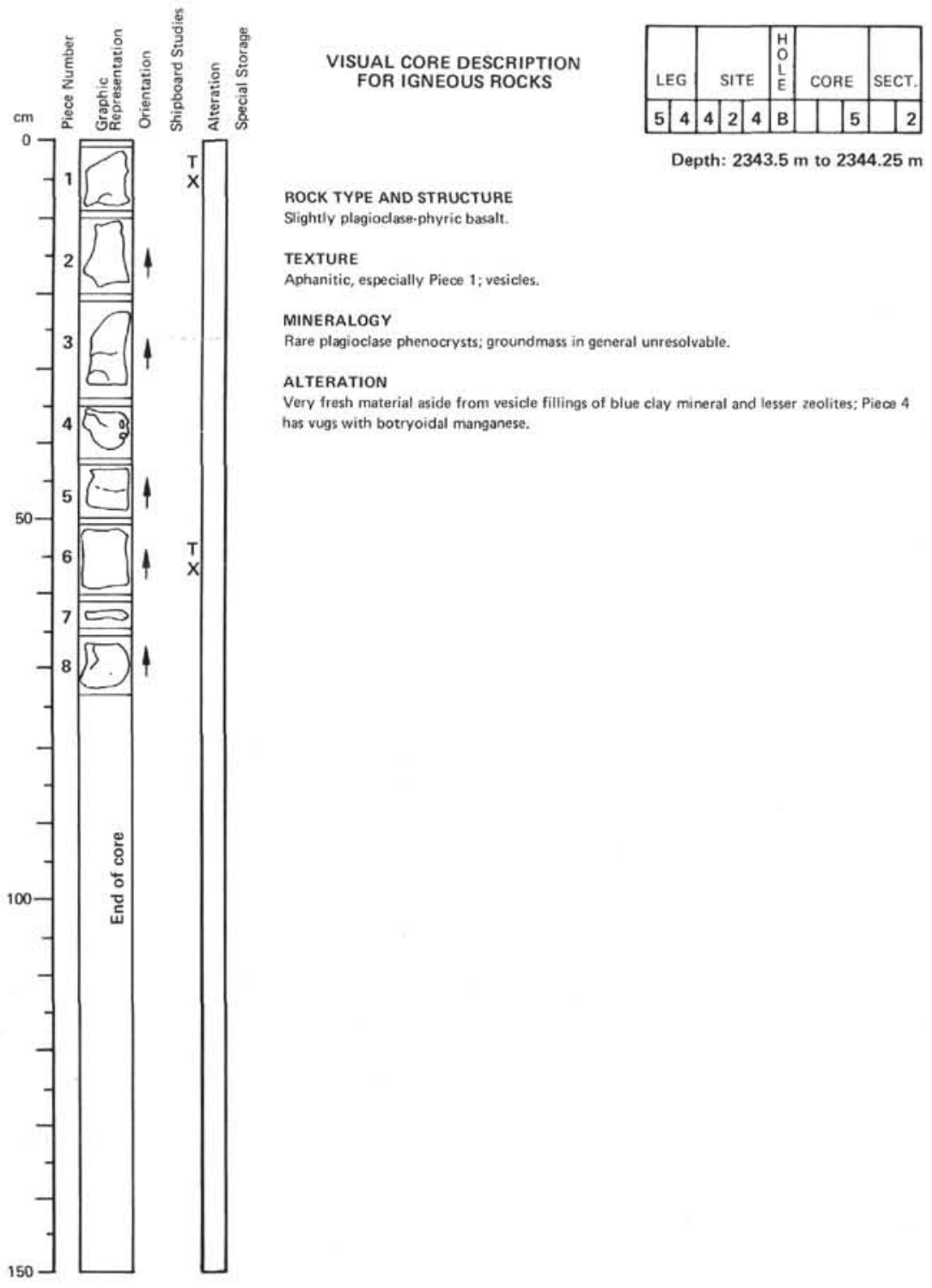




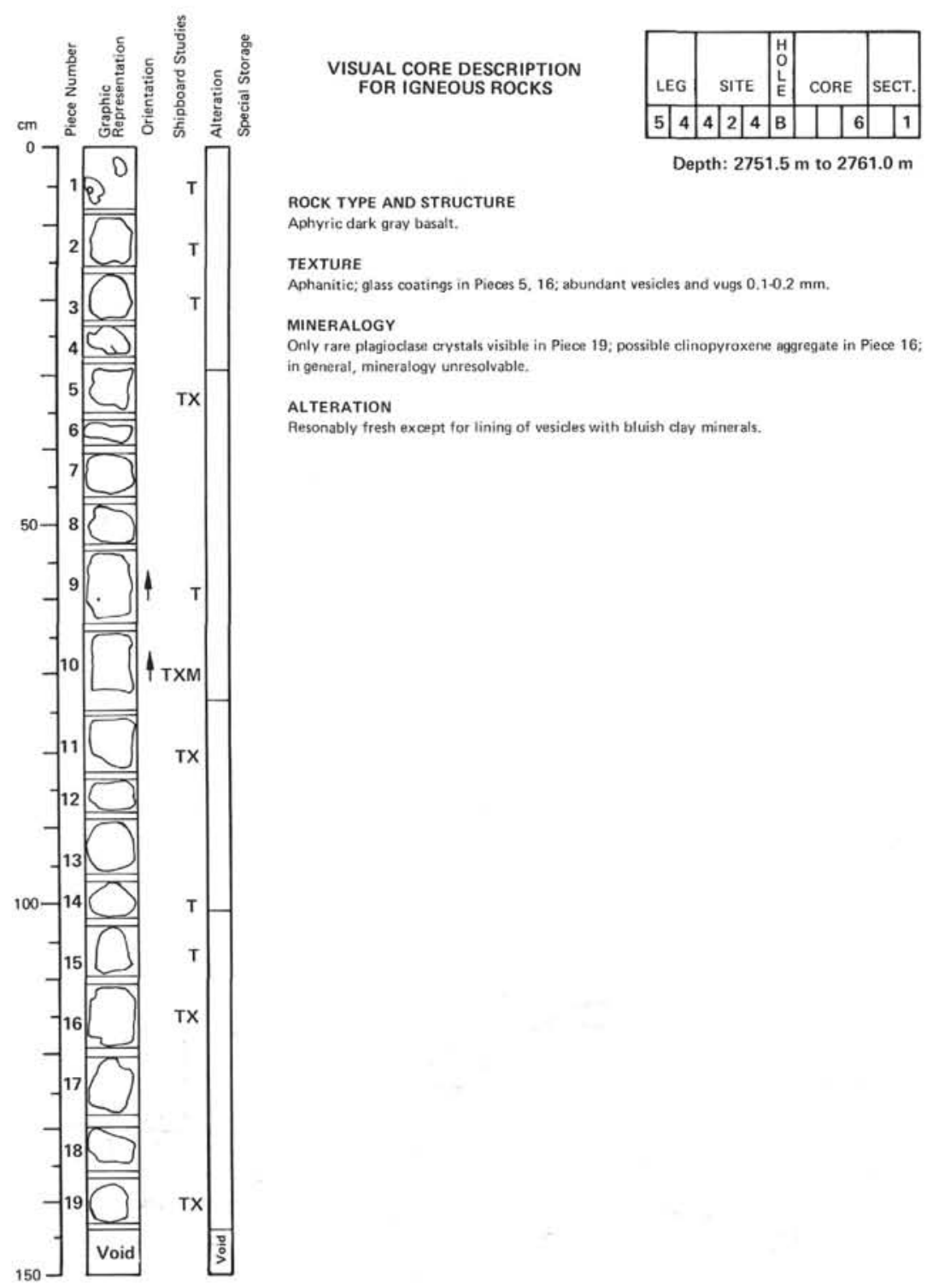




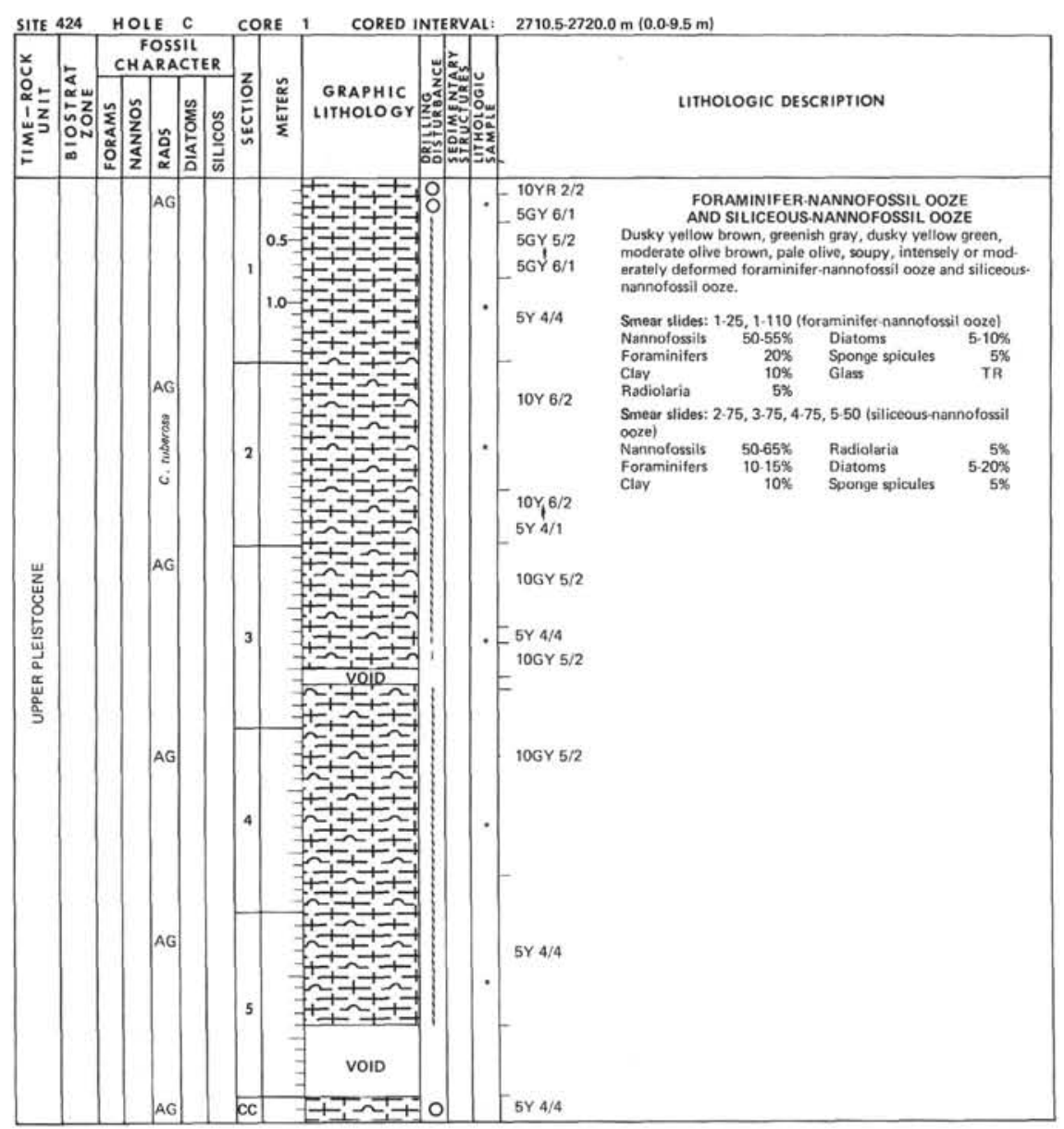



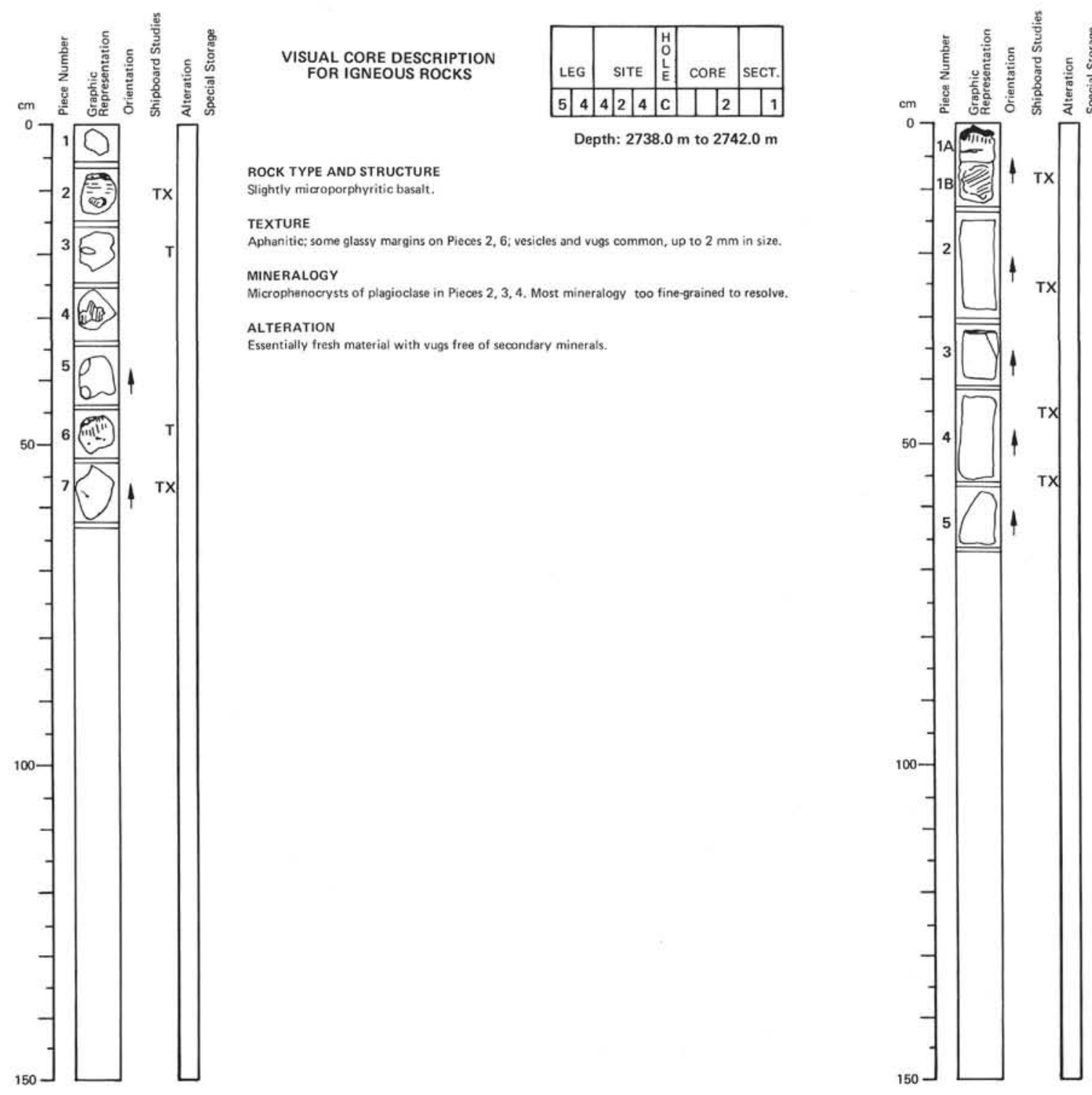

Aphyric basalt.

TEXTURE

Aphanitic; glassy fringes on Piece 1; some vesicles present, $0.5 \mathrm{~mm}$.

MINERALOGY

Only rare microphenocrysts of plagioclase, Pieoss 2,3: groundmass too fine-grained to resolve.

ALTERATION

Essentially fresh material; rust-colored and greenish secondary minerals in vugs of Piecos 18.4 . 

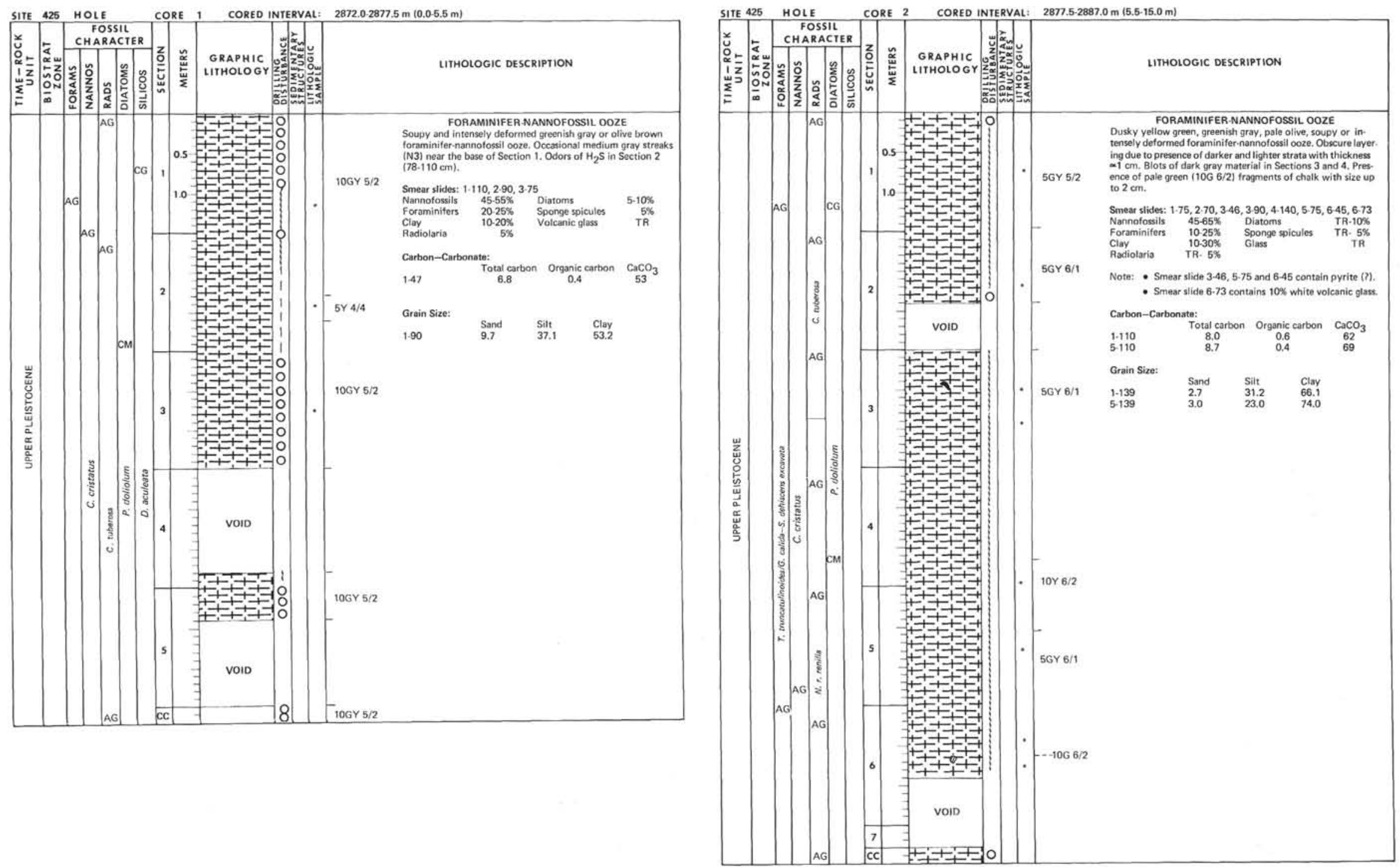

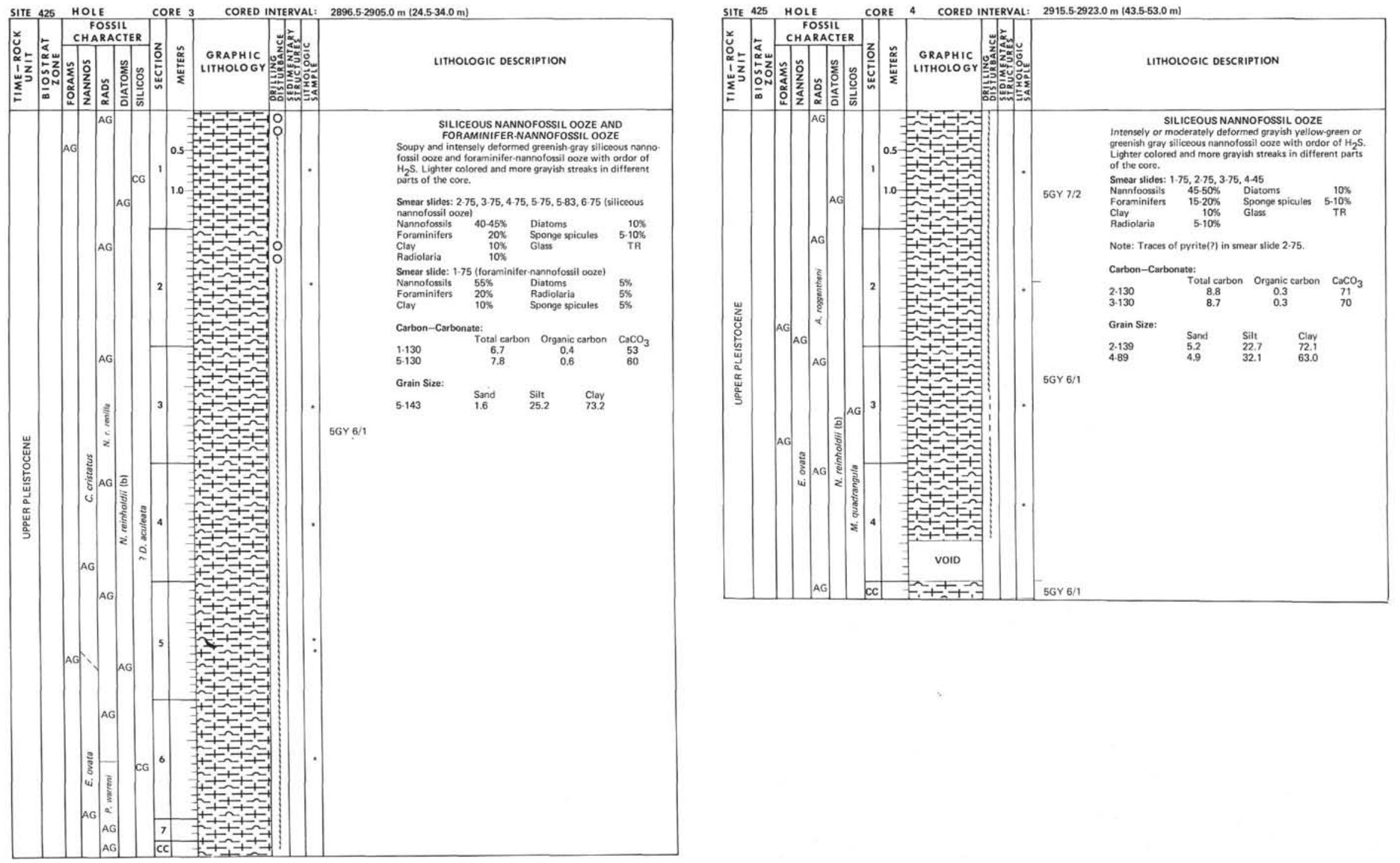

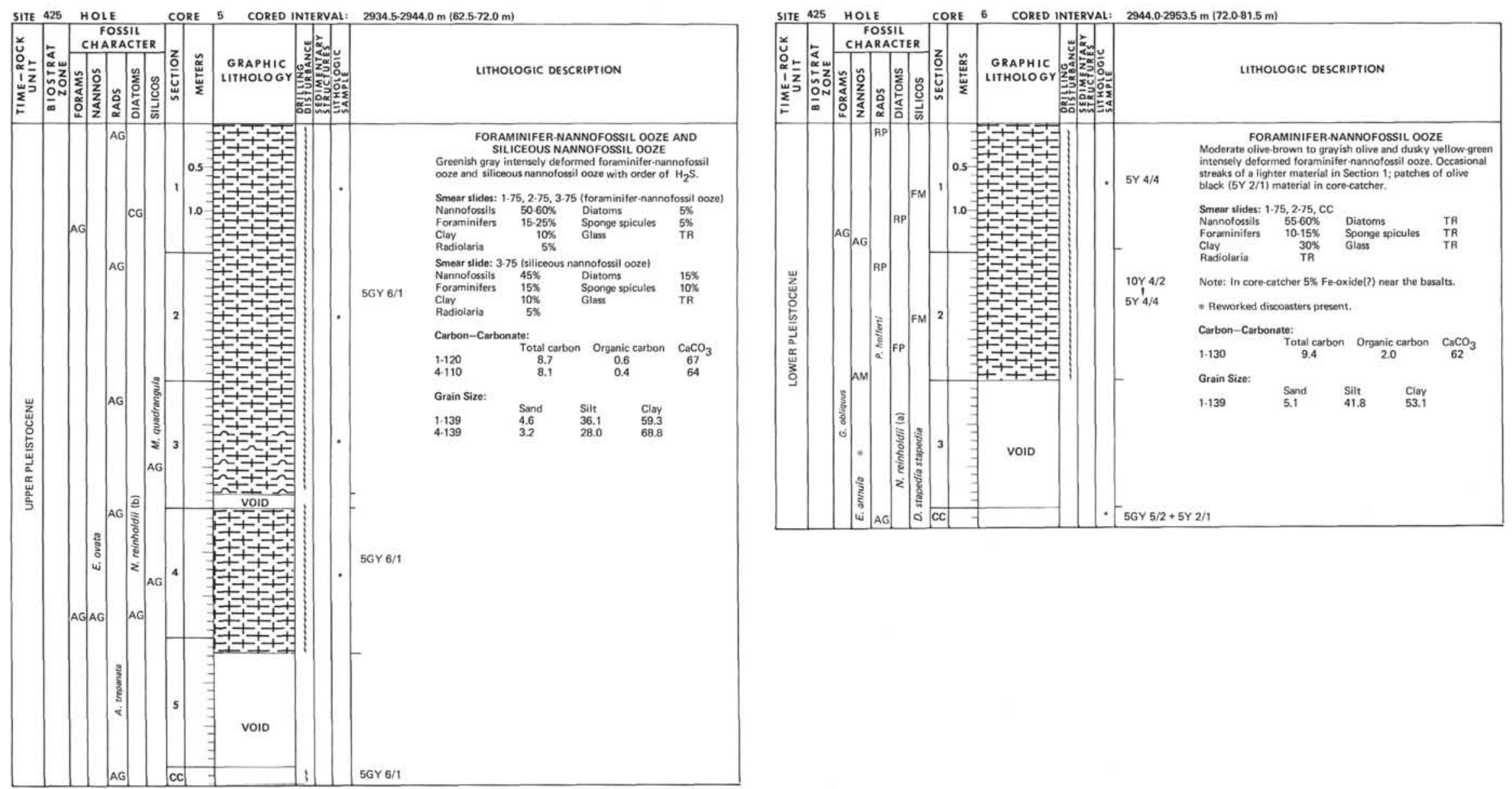


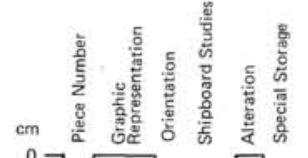

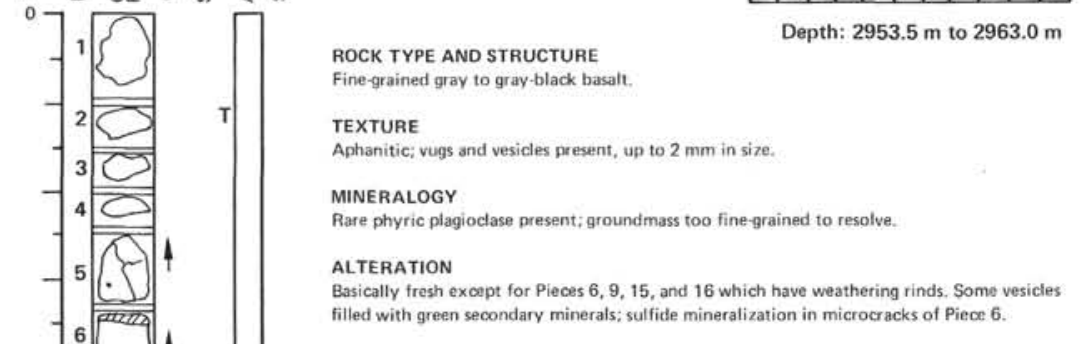

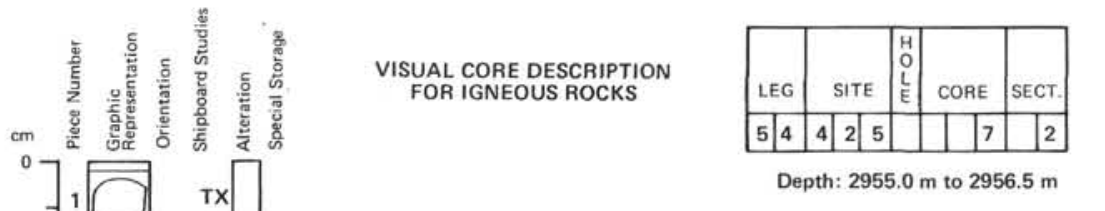

ROCK TYPE AND STRUCTURE

Medium-grained plagioclase-phytic basalı

TEXTURE

Aphanitic to medium-grained; some microphenocrysts observed in Piece 7; vugs and vesicles

present.

MiNERALOGY

Plagioclase and minor clinopyroxene as microphenocrysts (7); groundmass unresolvable in hand ALTERATION

Prominent alteration rinds, $0.5 \mathrm{~mm}$ thick, on most pieces; vesides filled with green clays (zeolites,

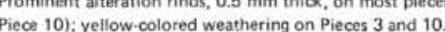
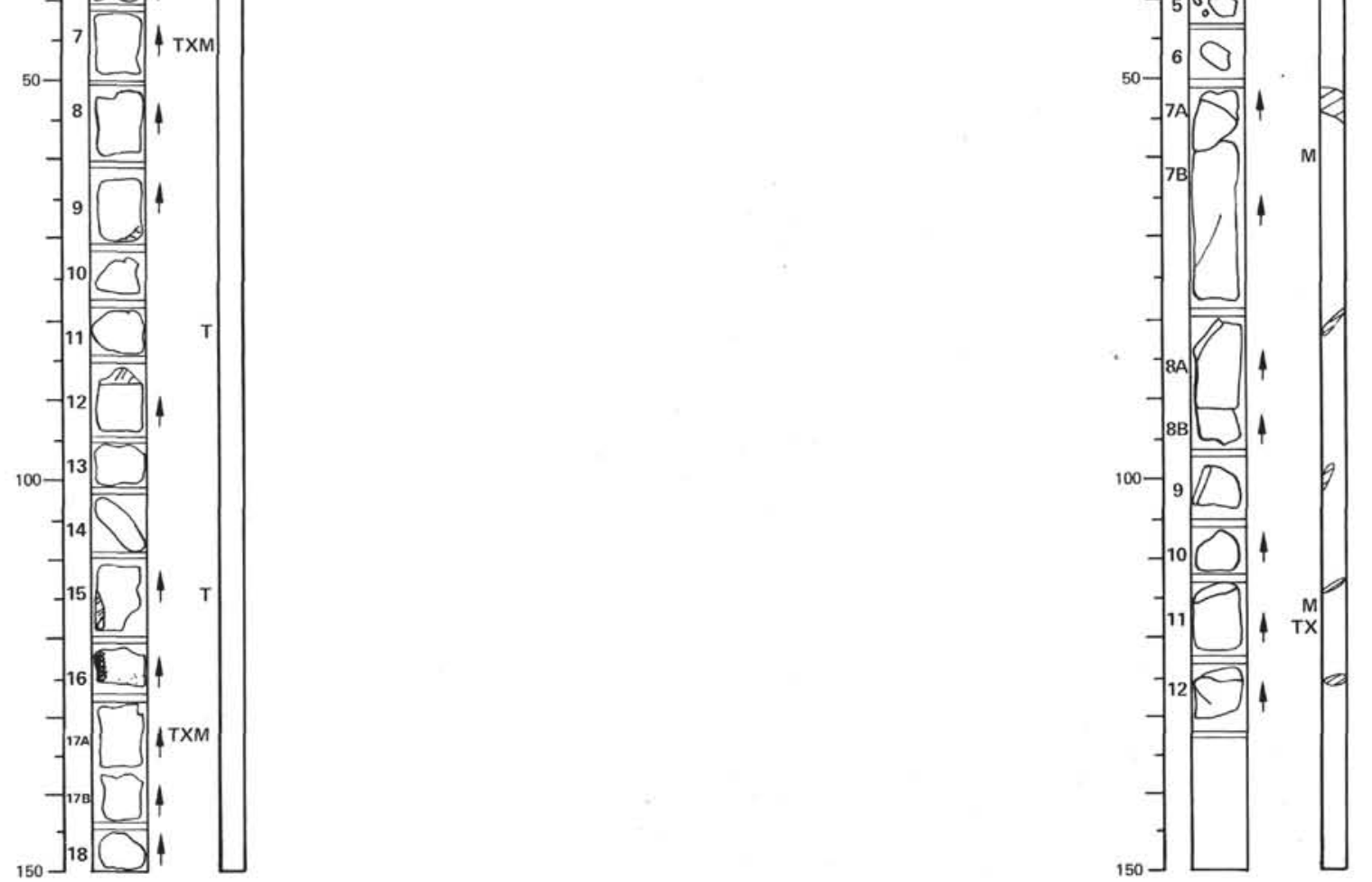


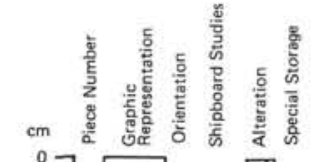

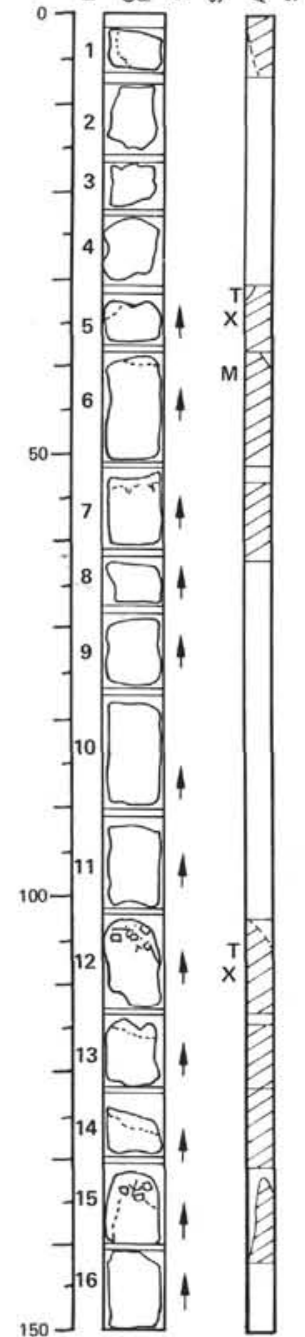

VISUAL CORE DESCRIPTION
FOR IGNEOUS ROCKS

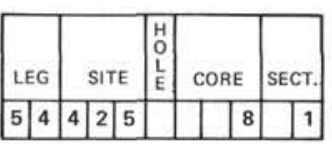

Depth: $2963.0 \mathrm{~m}$ to $2964.5 \mathrm{~m}$

\section{ROCK TYPE AND STRUCTURE}

Medum-grained to coarse-grained basalt; vugs and vesicles present.

MinerALOGY

Olivine, clinopyroxene, and plagioclase as phenocrysts in Piece 12: most groundmass crystals not large enough to resolve.

ALTERATION

5-7. 12.15: groundmass

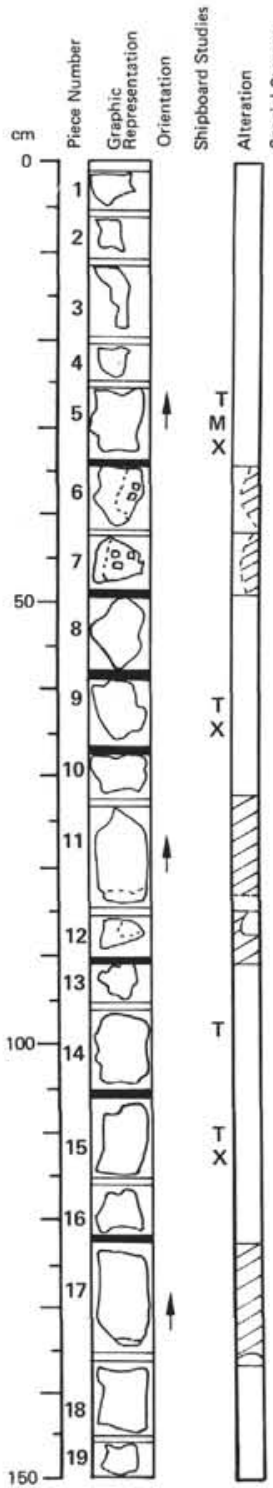

VISUAL CORE DESCRIPTION

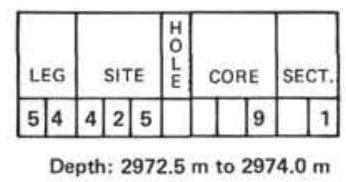

ROCK TYPE AND STRUCTURE

Sparsely plagioclase phyric basalt.

TEXTURE

MINERALOGY

Plagio unresolvable in hand sample.

ALTERATION

Th on Pieces $6,7,11,12,17$. Vesicles filled with green and brown 

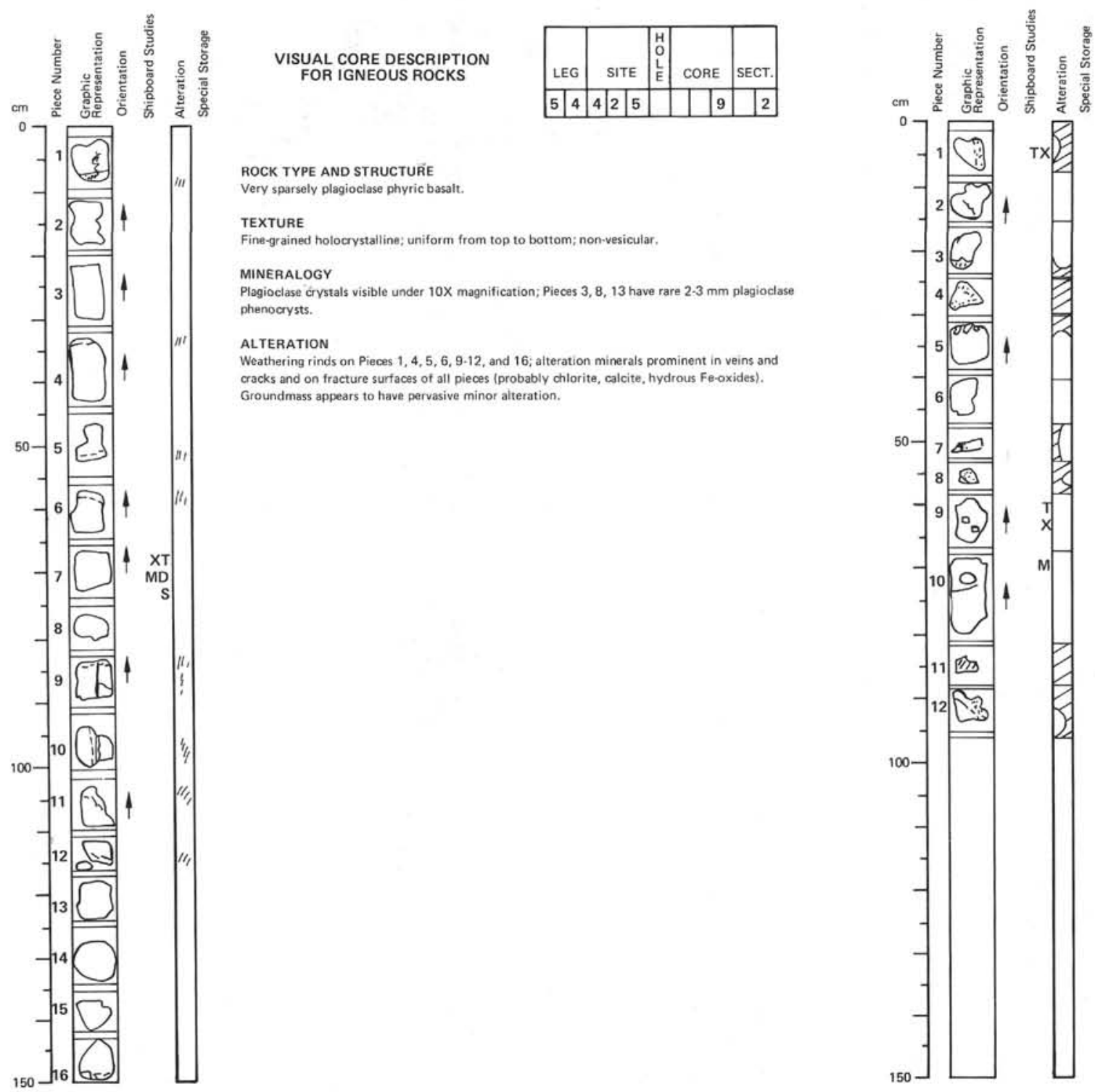
VISUAL CORE DESCRIPTION

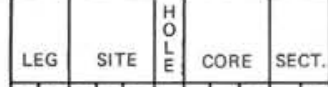
\begin{tabular}{|l|l|l|l|l|l|l|l|}
\hline 5 & 4 & 4 & 2 & 5 & & & 9 \\
\hline
\end{tabular}

ROCK TYPE AND STRUCTURE

Very sparsely plagioclase phyric basal

TEXTURE

Fine-grained holocrystalline: uniform from top to bottom; non-vesicular.

MiNERALOGY

Plagioclase cry
phenocyrysts.

ALTERATION

1. $1,5,6,9-12$, and 16 ; alteration minerals prominent in veins and

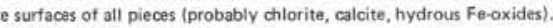

Groundmass appears to have pervasive minot alteration.

TEXTURE

.

MINERALOGY

efysts: most material too tine-grained to resolve.

ALTERATIONS

(a) zeolites and calcite: Piece 11 badly altered; Piece 7 has vein of secondary minerals. 


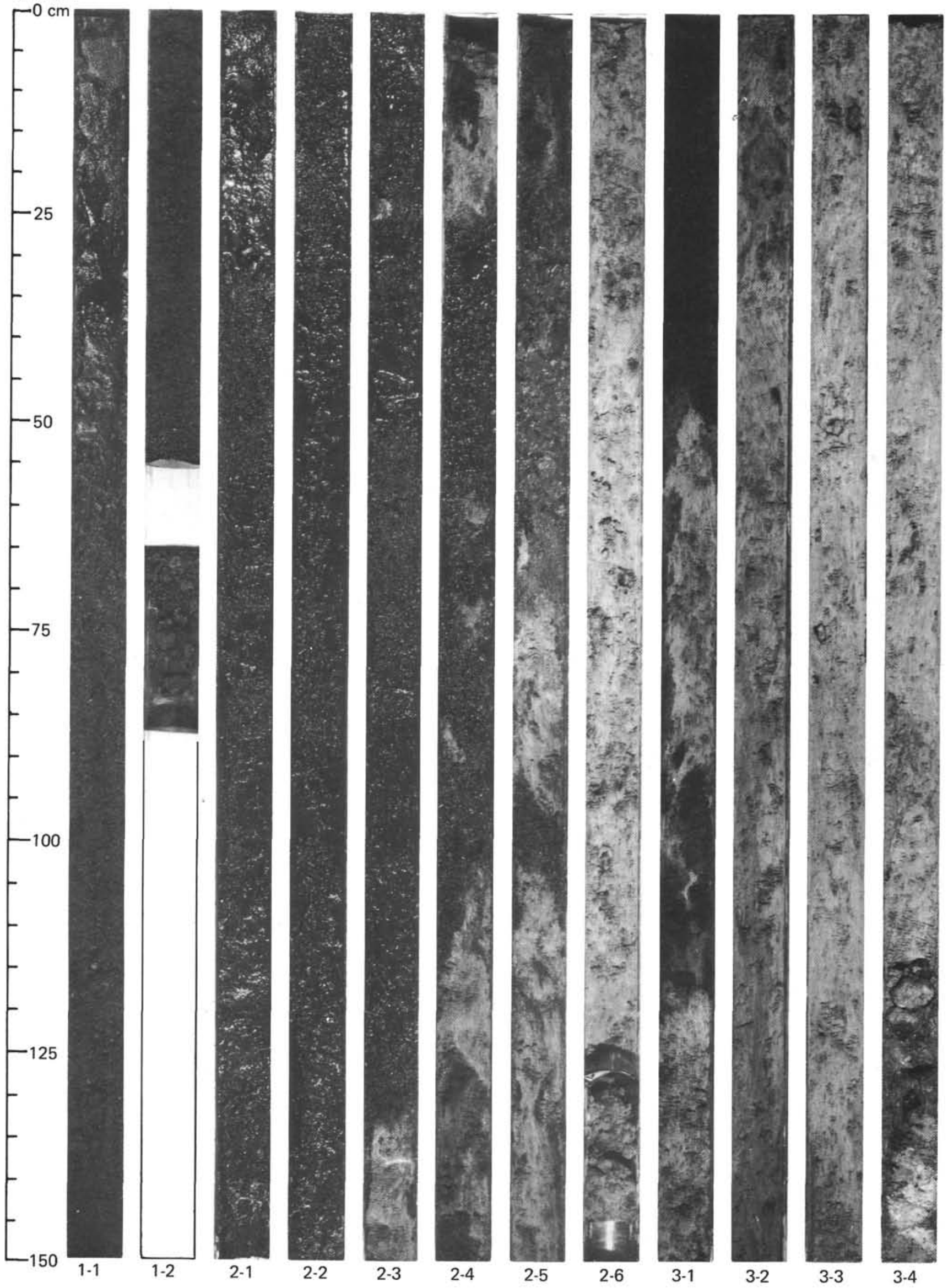




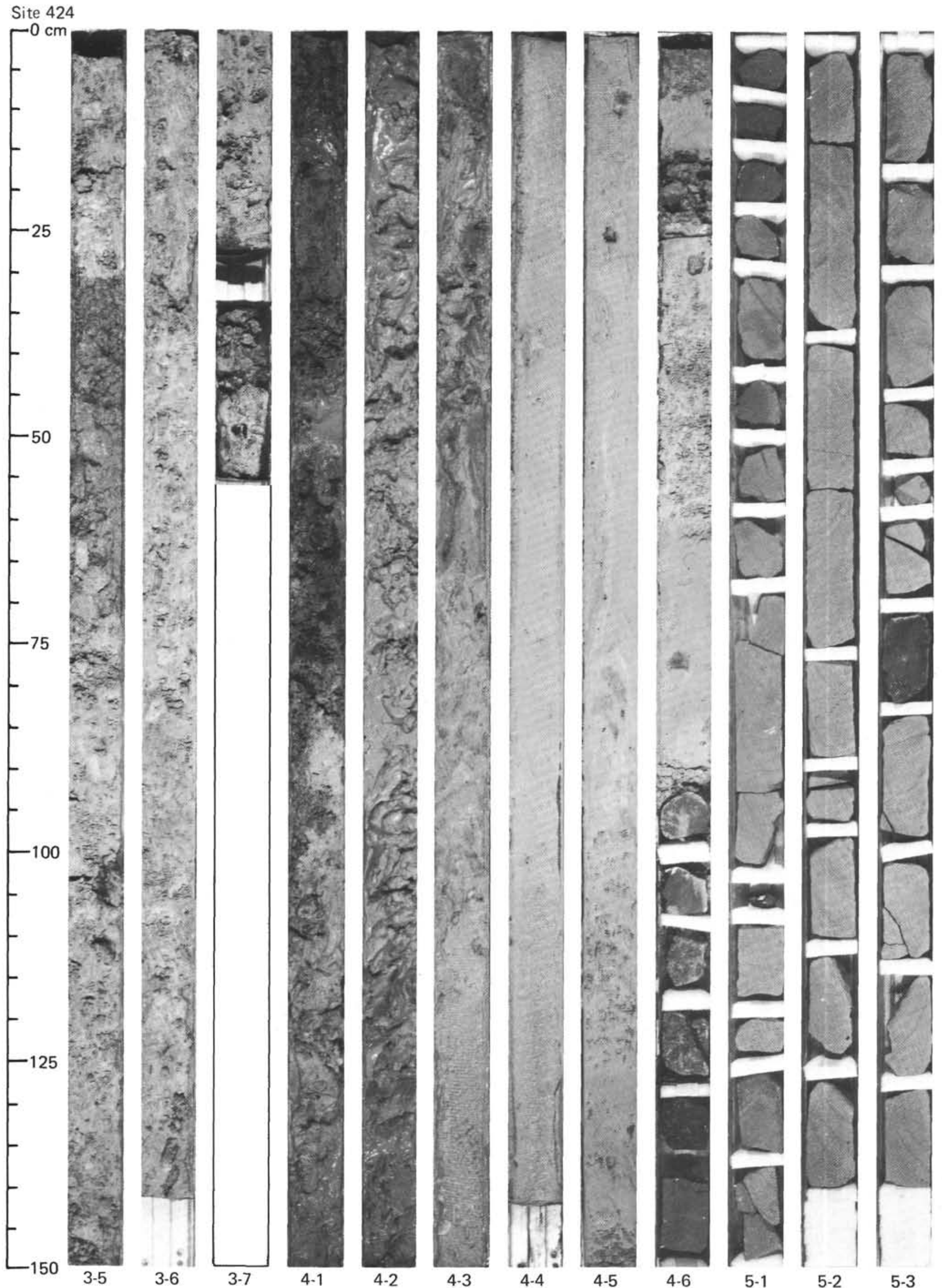


Site 424

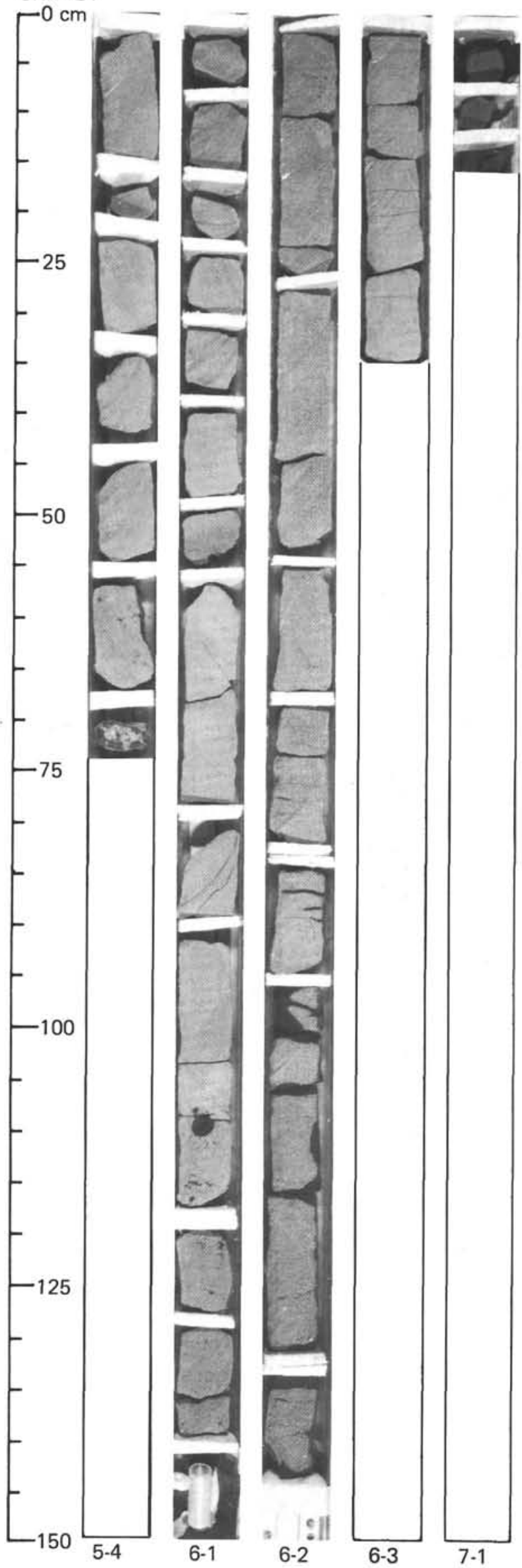


Hole 424B

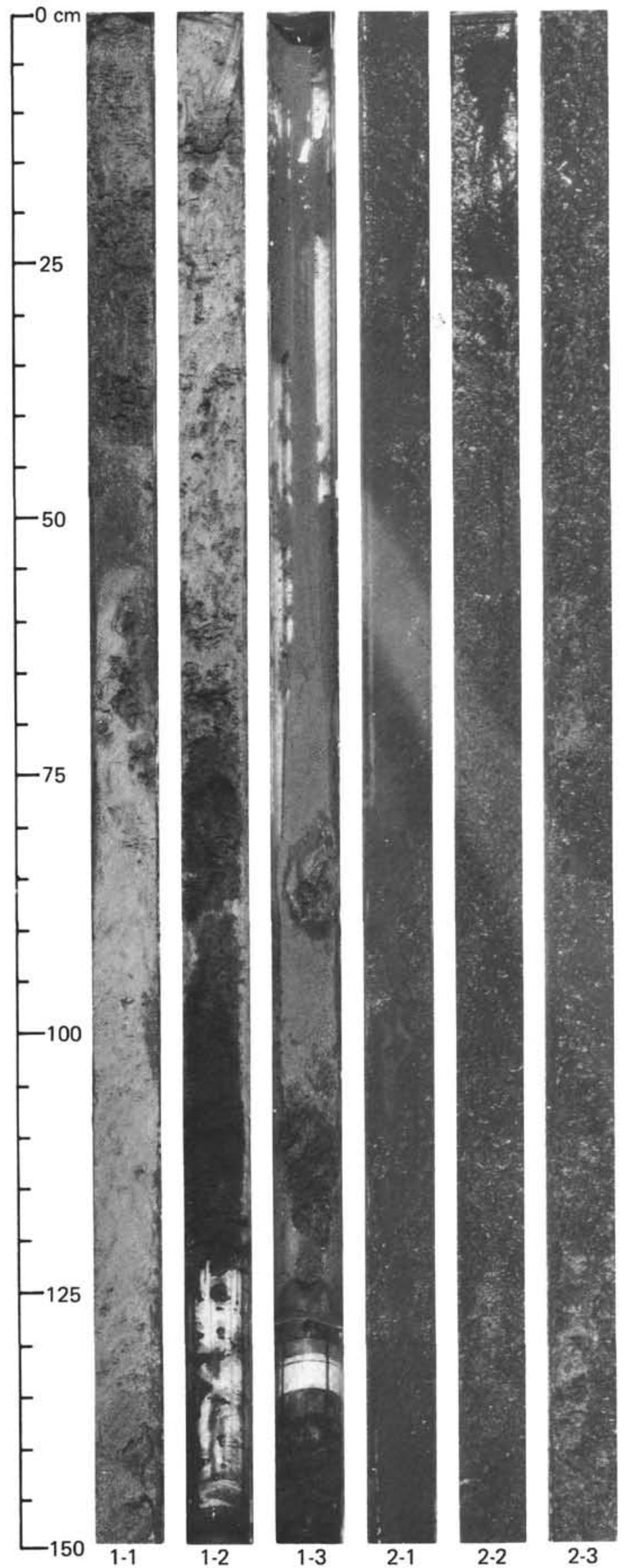

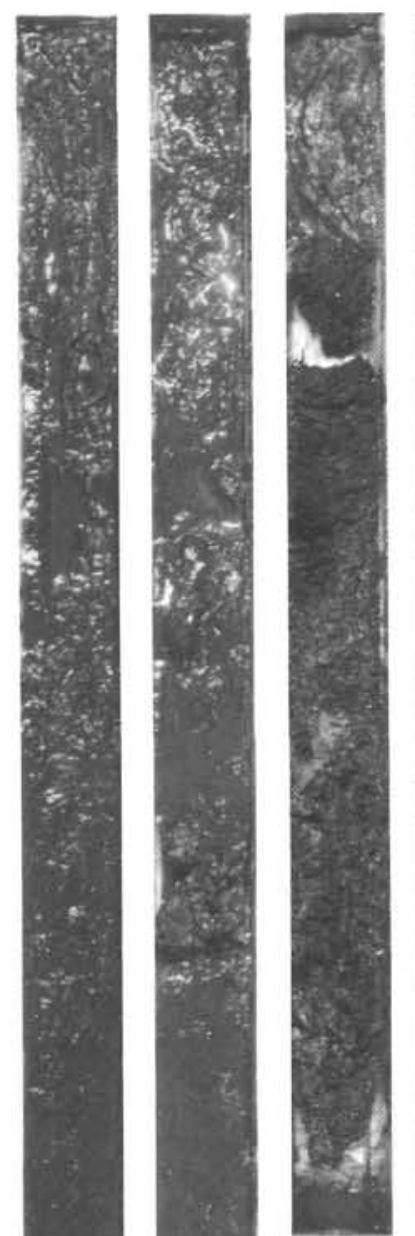
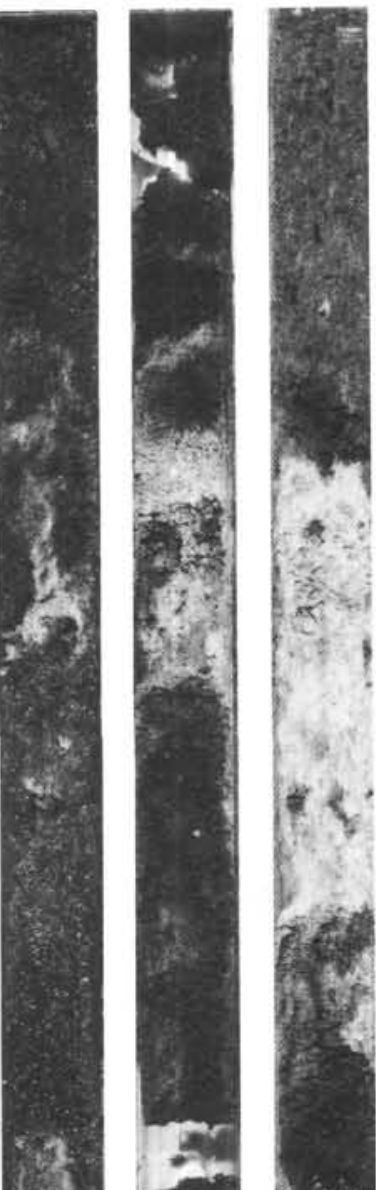

(6)

in

f. की

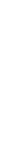

is.
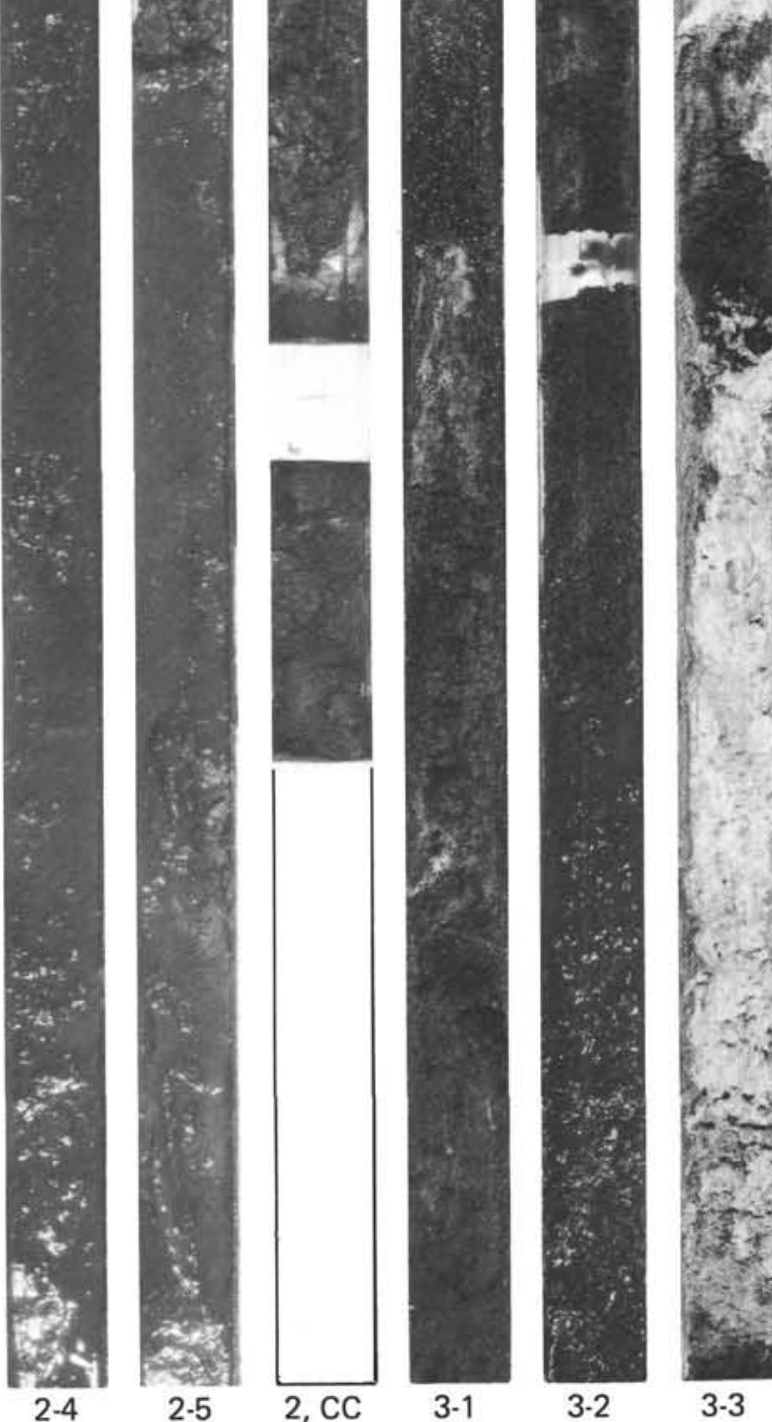

3-1

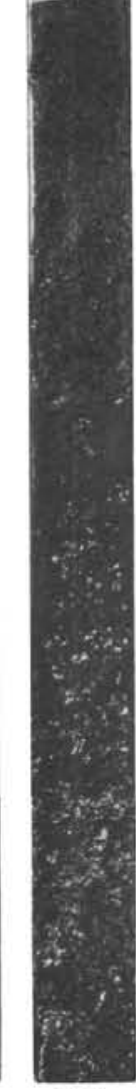

3-2

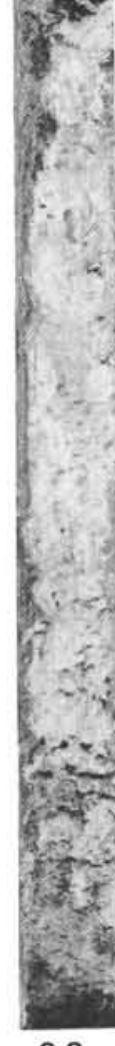


Hole 424B

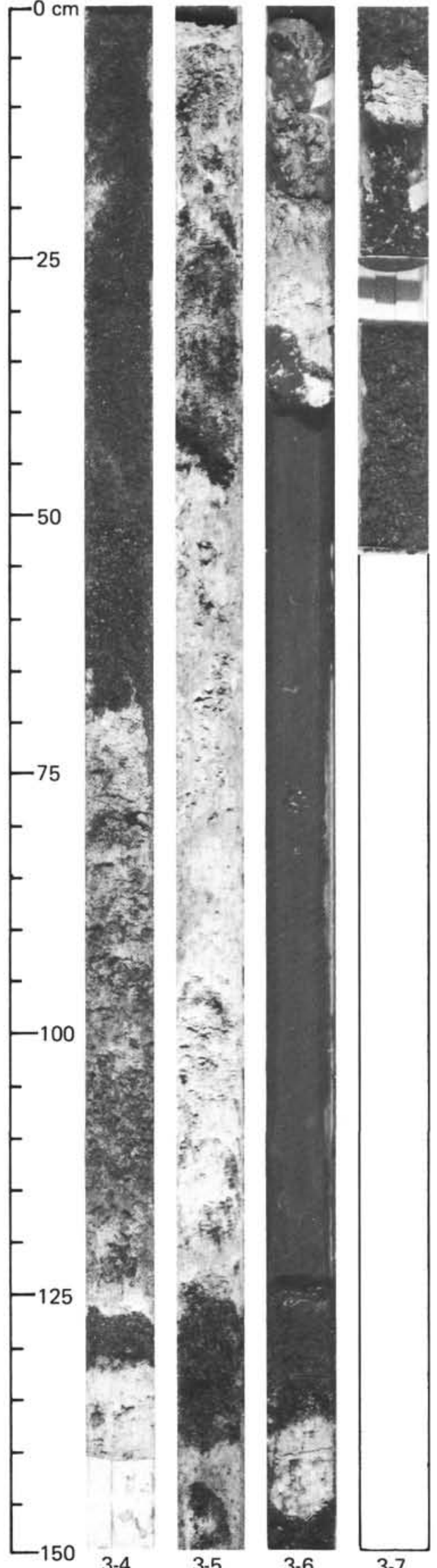

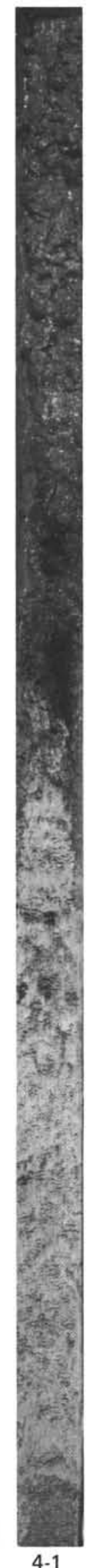

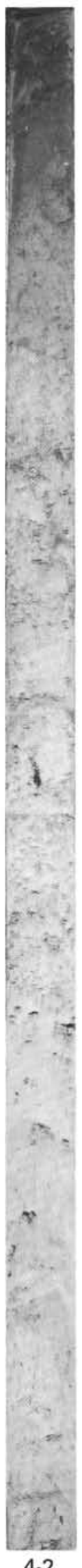

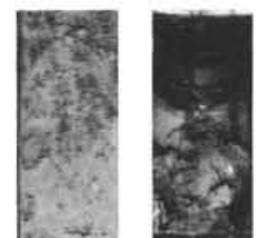
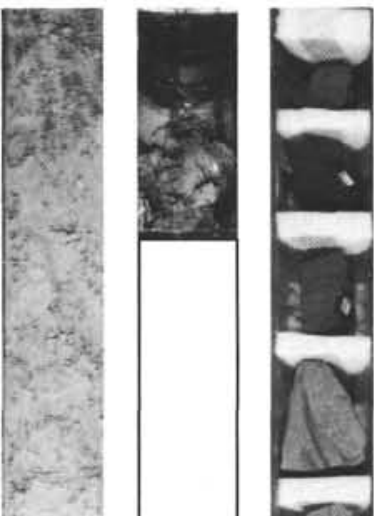

醮

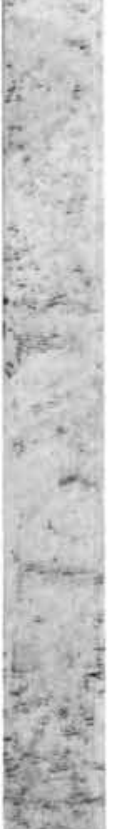

fexs:

$x_{0}^{2}, y^{2}$

lies

51은

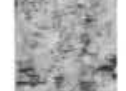

sites

है

int

aring

2.

Q.

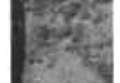

istos?

ising

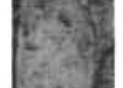

It)

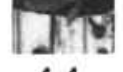

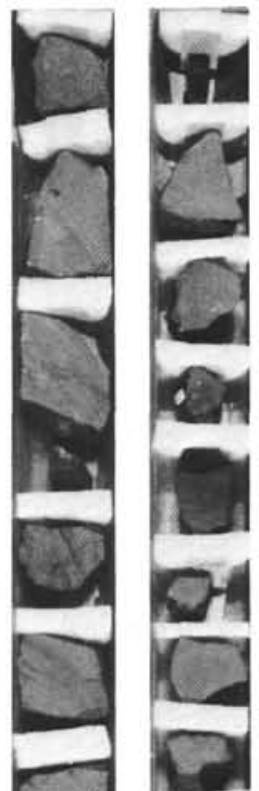
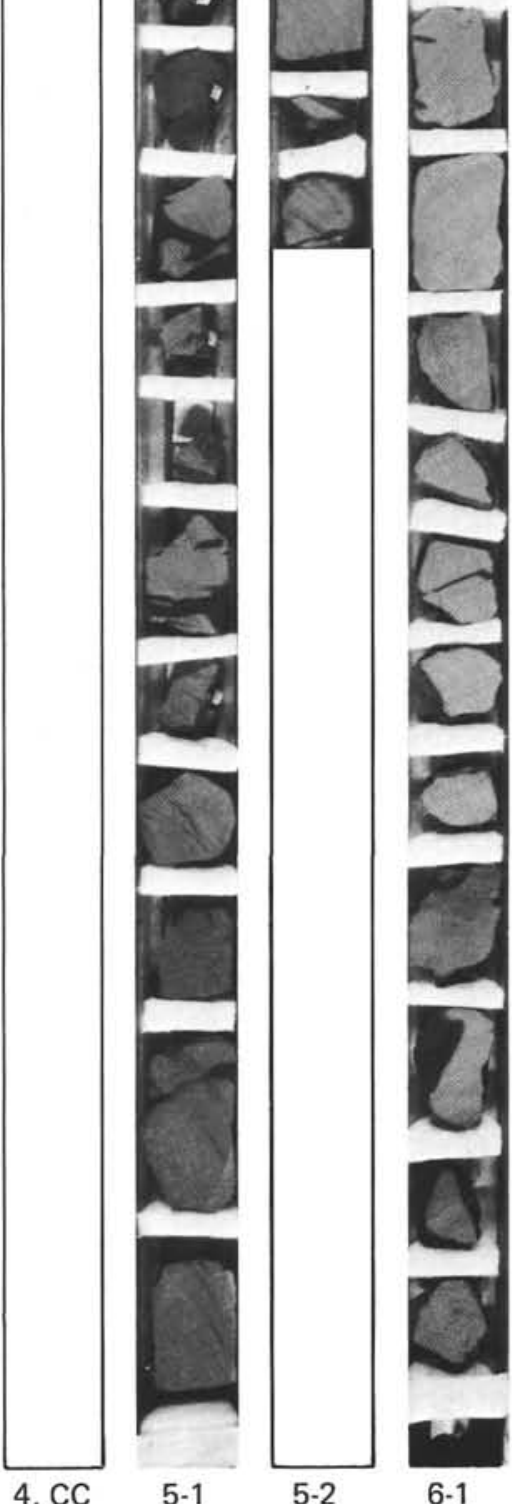

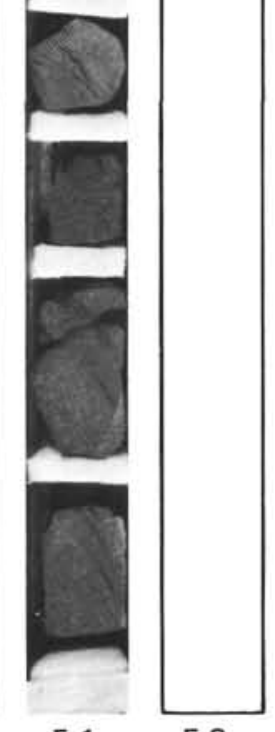

$5-2$

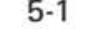


Hole 424C

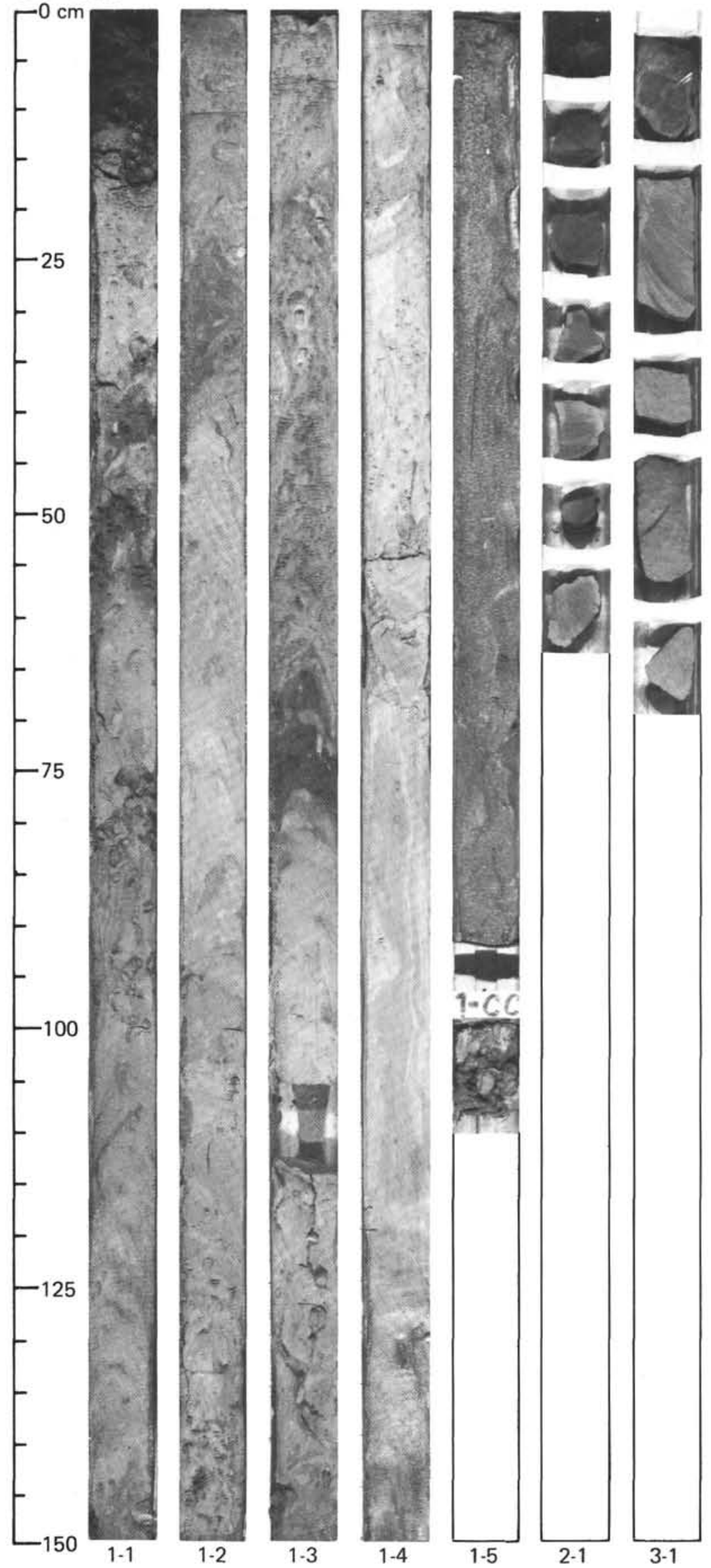

Site 425
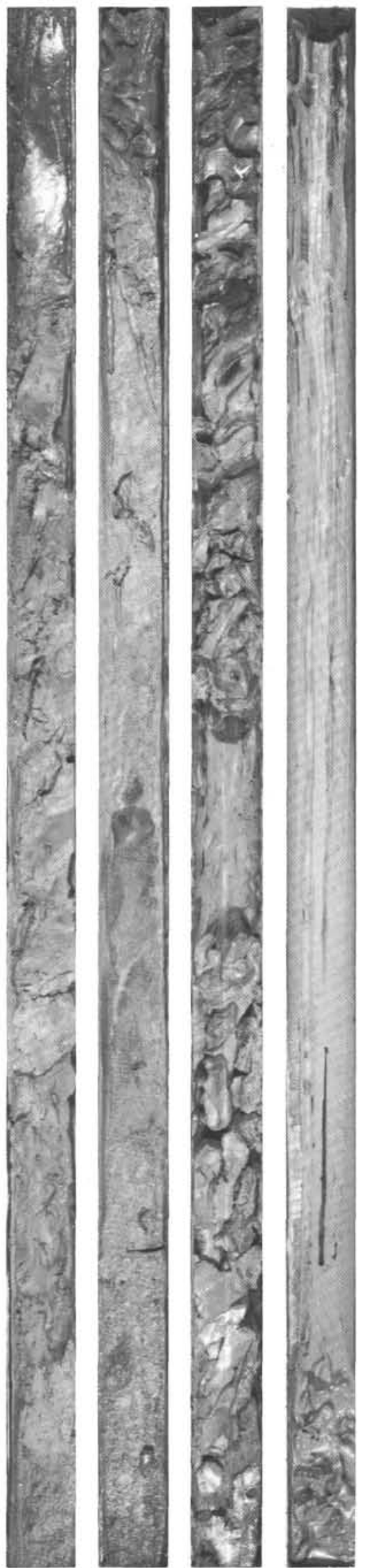

$1-3$

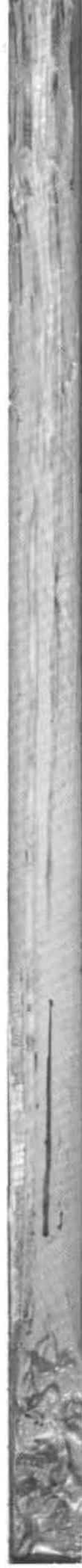

$1-1$

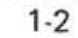

$1-4$ 
Site 425

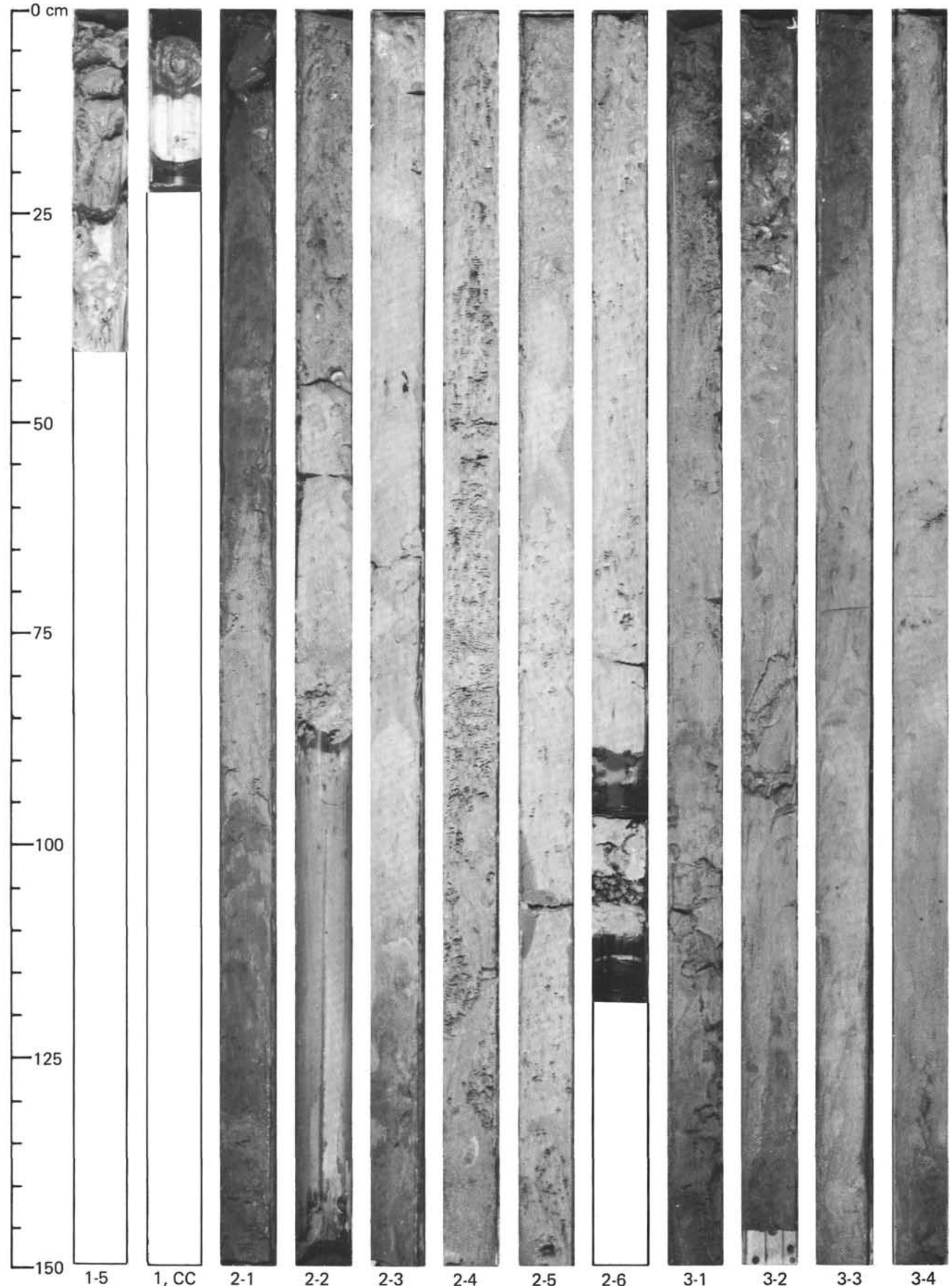




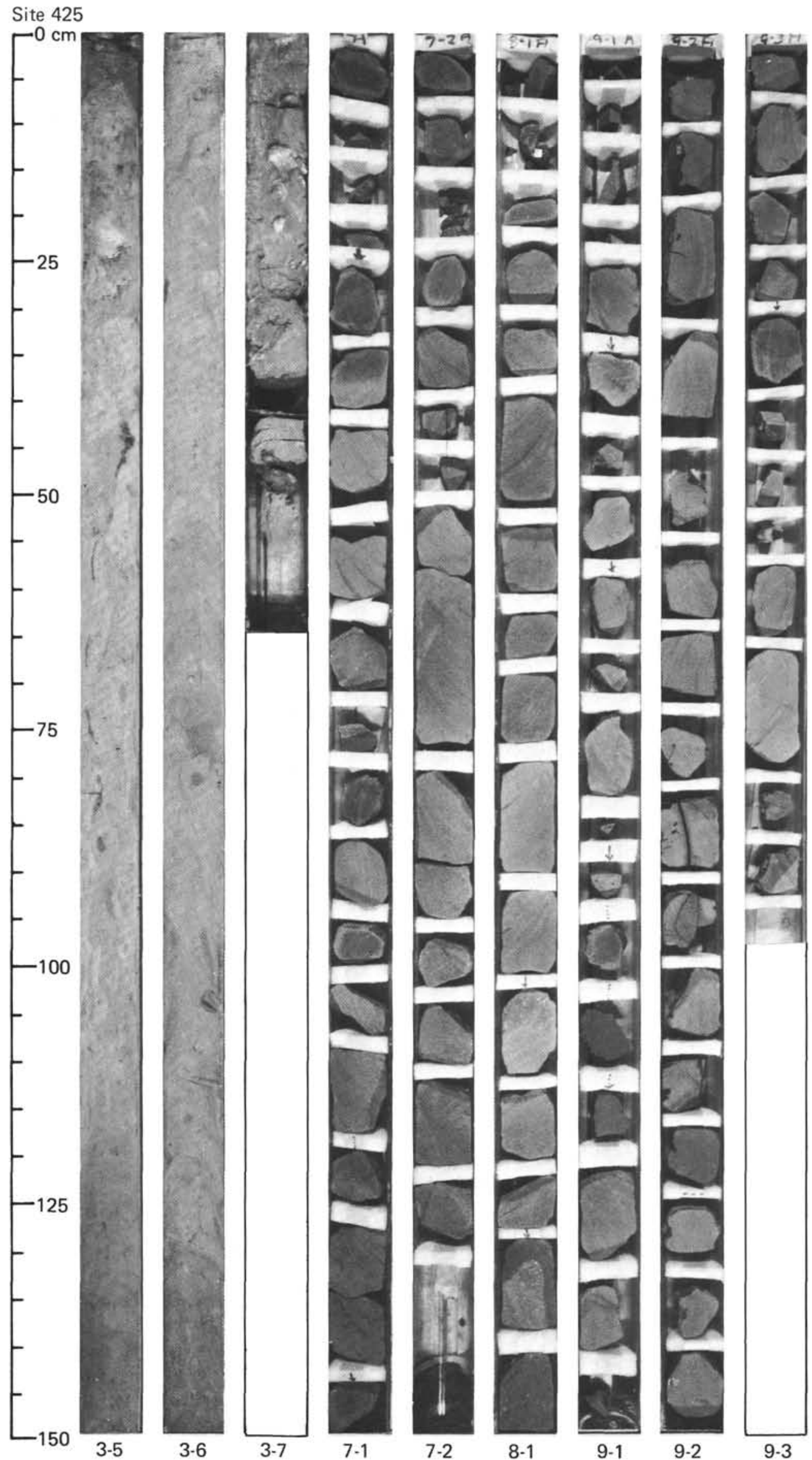

